\title{
Empirical Studies Assessing the Quality of Health Information for Consumers on the World Wide Web A Systematic Review
}

Gunther Eysenbach, MD

John Powell, MSc, MRCPsych, MFPHM

Oliver Kuss, PhD

Eun-Ryoung Sa, MS

$\mathrm{T}$ HE INTERNET HAS BECOME AN IMportant mass medium for consumers seeking health information and health care services online. ${ }^{1}$ A recent concern and public health issue has been the quality of health information on the World Wide Web. However, the scale of the problem and the "epidemiology" (distribution and determinants) of poor health information on the Web are still unclear, as is their impact on public health and the question of whether poor health information on the Web is a problem at all. ${ }^{2}$ Many studies have been conducted to describe, critically appraise, and analyze consumer health information on the Web. These typically report proportions of inaccurate or imperfect information as estimates of the prevalence of flawed information or the risk of encountering misinformation on the Web.

However, to date no systematic and comprehensive synthesis of the methodology and evidence has been attempted. Two previous systematic reviews focused on compiling quality criteria and rating instruments, but did not synthesize evaluation results. Jadad and Gagliari ${ }^{3}$ reviewed nonresearch-based rating systems (eg, cri-

For editorial comment see p 2713.

Context The quality of consumer health information on the World Wide Web is an important issue for medicine, but to date no systematic and comprehensive synthesis of the methods and evidence has been performed.

Objectives To establish a methodological framework on how quality on the Web is evaluated in practice, to determine the heterogeneity of the results and conclusions, and to compare the methodological rigor of these studies, to determine to what extent the conclusions depend on the methodology used, and to suggest future directions for research.

Data Sources We searched MEDLINE and PREMEDLINE (1966 through September 2001), Science Citation Index (1997 through September 2001), Social Sciences Citation Index (1997 through September 2001), Arts and Humanities Citation Index (1997 through September 2001), LISA (1969 through July 2001), CINAHL (1982 through July 2001), PsychINFO (1988 through September 2001), EMBASE (1988 through June 2001), and SIGLE (1980 through June 2001). We also conducted hand searches, general Internet searches, and a personal bibliographic database search.

Study Selection We included published and unpublished empirical studies in any language in which investigators searched the Web systematically for specific health information, evaluated the quality of Web sites or pages, and reported quantitative results. We screened 7830 citations and retrieved 170 potentially eligible full articles. A total of 79 distinct studies met the inclusion criteria, evaluating 5941 health Web sites and 1329 Web pages, and reporting 408 evaluation results for 86 different quality criteria.

Data Extraction Two reviewers independently extracted study characteristics, medical domains, search strategies used, methods and criteria of quality assessment, results (percentage of sites or pages rated as inadequate pertaining to a quality criterion), and quality and rigor of study methods and reporting.

Data Synthesis Most frequently used quality criteria used include accuracy, completeness, readability, design, disclosures, and references provided. Fifty-five studies ( $70 \%)$ concluded that quality is a problem on the Web, $17(22 \%)$ remained neutral, and 7 studies $(9 \%)$ came to a positive conclusion. Positive studies scored significantly lower in search $(P=.02)$ and evaluation $(P=.04)$ methods.

Conclusions Due to differences in study methods and rigor, quality criteria, study population, and topic chosen, study results and conclusions on health-related Web sites vary widely. Operational definitions of quality criteria are needed.

www.jama.com

Author Affiliations: Unit for Cybermedicine and EHealth, Department of Clinical Social Medicine, University of Heidelberg, Heidelberg, Germany (Dr Eysenbach); Health Services Research Unit, London School of Hygiene and Tropical Medicine, London, England (Dr Powell); Department of Medical Epidemiology, Biometry and Informatics, University of Halle-Wittenberg, Halle/Saale, Germany (Dr Kuss); and Global Health
Network Group, Department of Epidemiology, University of Pittsburgh, Pittsburgh, Pa (Ms Sa). Dr Eysenbach is now with the Centre for Global eHealth Innovation, Toronto General Hospital, Toronto, Ontario. Corresponding Author and Reprints: Gunther Eysenbach, MD, Centre for Global eHealth Innovation, Toronto General Hospital, 190 Elizabeth St, Toronto, Ontario, Canada M5C 2C4 (e-mail: ey@yi.com). 
teria used for "awards," "seals of approval," or gateways) published on the Internet but did not include rating systems published in the peer-reviewed literature. Kim et $\mathrm{al}^{4}$ compiled instruments or criteria proposed to evaluate Web sites, but it is unclear to what extent and with what results these criteria can be and have been applied in practice.

To our knowledge, this is the first systematic review conducted to compile criteria actually used and to synthesize evaluation results from studies containing quantitative data on structure and process measures of the quality of health information on the Web. The objectives of this study were to establish a methodological framework on how "quality" on the Web is evaluated in practice, to determine the heterogeneity of the results and conclusions, to compare the methodological rigor of these studies, to determine to what extent the conclusions depend on the methodology used, and to suggest future directions for research.

\section{METHODS}

\section{Inclusion and Exclusion Criteria}

Inclusion and exclusion criteria were established in advance in a written protocol. Studies were included when their authors: (1) searched the World Wide Web systematically for health information (eg, to identify all consumer Web sites for a given topic) or clearly defined a set of specific health information services to be included; (2) evaluated information likely to be accessed by consumers; (3) evaluated the quality of health information or services against certain criteria-for example, by judging the authority of source; assessing the accuracy of information, readability, or comprehensiveness; or by comparing Internet information and services against those outside of the Internet; and (4) provided quantitative results, such as proportions of Web sites complying with the quality criteria, or the distribution of quality scores, or information on the readability level(s) in the sample.

Studies were excluded if authors simply listed "quality" Web sites without in- dicating that they had performed a comprehensive, systematic search, if they did not list quality criteria, or if they did not quantitate how many Web sites were assessed in total or how many did not comply with quality criteria. We also excluded studies assessing tools that enable or facilitate access to health information, such as search engines, directories, health portals, rating systems, and review services, or studies comparing different methods of information retrieval. Theoretical papers that only described quality criteria alone were also excluded, as were qualitative descriptions of Internet contents. We did not include studies that dealt with content other than health information, or studies evaluating information not intended for consumers (eg, those providing continuing medical education), but we did include studies evaluating services and information likely to be used by both professionals and consumers (eg, those providing drug information). Studies evaluating a single site or application were excluded, as were studies focusing exclusively on privacy and security issues, or on interactions via newsgroups or e-mail.

\section{Search Strategy}

We sought all relevant studies and unpublished reports, regardless of language or peer-review/publication status. We searched MEDLINE and PREMEDLINE (1966-September 2001) by entering the following query into the PubMed interface on September 20, 2001 (quality OR reliability OR accuracy OR readability $O R$ evaluation OR assessment) AND (information OR education OR advice) AND (internet OR web OR ehealth OR "e-health" OR cyber* OR www). We retrieved 1545 citations and their titles and abstracts were screened for potential relevance by 2 independent reviewers. In addition, 1 reviewer used analogous search terms to screen citations in LISA (Library and Information Science Abstracts Database, 1969- July 2001) (1269 hits), CINAHL Nursing and Allied Health (1982-July 2001) (2312 hits), PsychINFO (American Psychological Association, 1988-September 2001 [week
2]) (321 hits), EMBASE (Elsevier Science BV, Amsterdam/NL, 1988-June 2001) (647 hits), and SIGLE (Grey Literature in Europe database, 1980-June 2001) (83 hits). The Web of Science database (Institute for Scientific Information, Philadelphia, Pa), which includes the Science Citation Index (1997September 2001), the Social Sciences Citation Index (1997-September 2001), and the Arts and Humanities Citation Index (1997-September 2001) was searched using both a traditional backward search strategy (1120 hits) as well as using a forward citation-search strategy, using 5 seminal papers in this field ${ }^{3-7}$ as "seed publications" to identify all publications that subsequently cited 1 of these papers (533 hits). We also checked the references of all identified studies, hand-searched the Journal of Medical Internet Research (because it contains pertinent studies and because at that time it was not yet indexed on MEDLINE), conducted general Internet searches using combinations of the search terms at the Google and Northern Light search engines, reviewed 3 bibliographies of consumer health information studies collated by academic institutions, and used private literature databases.

In total, we screened 7830 citations and retrieved 165 potentially eligible full articles to determine whether they met the inclusion criteria. Articles in Hungarian, Japanese, French, Spanish, Dutch, and Italian were translated by professional translators into English or German.

\section{Data Extraction}

Two reviewers (G.E., J.P.) independently extracted study characteristics using electronic data extraction forms, maintaining all data in an Access database (Microsoft Corp, Redmond, Wash). Each extraction form contained 85 items, of which 43 were closed questions, mostly to be answered on a scale (yes/no/partially/ not applicable/to be discussed). We extracted information on search strategies used, quality criteria applied, and methodology of quality assessment used by authors, as well as quality and rigor of 
study methodology and reporting (see below and TABLE $\mathbf{1}$ ).

We rated the overall tone of the authors' conclusions as "negative" if authors were wary and pessimistic about the Web as a source for health information, "positive" if authors did not express concern or recommended the Web as a source for health information, or "neutral" if authors discussed both risks and benefits, or if the reviewers disagreed.

To extract evaluation results of each study, one reviewer tabulated data on how many Web sites or Web pages were evaluated for each quality criterion and how many of those evaluated did not comply with the respective criterion.

\section{Statistical Analysis}

To determine interobserver reliability for all coded items, we calculated standard $\kappa$ values for each extracted item reported on a binary scale (eg, include study: yes/no), or weighted $\kappa$ values for ordinal outcomes (eg, study characteristics graded on a scale [yes/partially/ no]). We decided in advance not to include items with $\kappa$ values less than 0.6. ${ }^{8}$ For the final consensus coding used for analysis, reviewers examined all disagreements or items coded "to be discussed" and resolved them by extensive discussion.

We used meta-analysis of proportions ${ }^{9}$ to test for homogeneity of results for quality criteria that have been used by 3 or more authors to assess Web sites. We pooled study results for a given quality criterion if the assumption of homogeneity could not be rejected on a significance level of less than .05 .

To test whether the different conclusions of studies could be explained by their different quality scores we compared study assessment scores of study groups using the Wilcoxon test and logistic regression. All calculations were performed using SAS versions 6.12 and 8.2 (SAS Institute Inc, Cary, NC).

\section{Quality Scores}

We summarized the quality of reporting and the rigor of the studies by checking whether authors reported certain items deemed important for a well-reported, systematic, and comprehensive Internet search strategy (ie, S-score for search quality; range, 0-8 [transformed to percentage score]), and items thought to indicate a rigorous evaluation (ie, E-score for evaluation quality; [range, 0-10 [transformed to percentage score]). To ascertain face validity, an initial list of candidate items was compiled by 2 reviewers (G.E., J.P.) independently and later combined by consensus. As studies systematically evaluating Web information resemble in some ways systematic research overviews, the candidate criteria for the S-score partly derived from corresponding checklists. ${ }^{10}$ To ascertain score reliability, we eliminated items for which $\kappa$ was less than 0.6 ; the remaining items are shown in Table 1 . One point was given per item reported in order to calculate a raw summary score for search quality and evaluation quality. The final reported S-score and E-score

\begin{tabular}{|c|c|c|c|c|c|}
\hline Study Characteristics & Yes & No & Partially & NA & $\kappa$ \\
\hline Total included studies & 79 & 85 & $\ldots$ & $\ldots$ & 0.93 \\
\hline \multicolumn{6}{|l|}{ Assessment target } \\
\hline Completeness & 19 & 39 & $21 \ddagger$ & $\ldots$ & 0.90 \\
\hline Technical criteria & 53 & 26 & $\ldots$ & $\ldots$ & 0.77 \\
\hline Readability & 11 & 63 & $5 \S$ & $\ldots$ & 0.89 \\
\hline Design (aesthetics) & 15 & 64 & $\ldots$ & $\ldots$ & 0.89 \\
\hline \multicolumn{6}{|l|}{ Search quality (S-score) } \\
\hline Search tools mentioned & 60 & 13 & 4 & 2 & 0.77 \\
\hline More than 1 search tool used & 54 & 21 & 29 & 2 & 0.92 \\
\hline Search terms mentioned & 54 & 16 & 1 & 8\# & 0.95 \\
\hline $\begin{array}{l}\text { Consumer involvement, eg, when devising } \\
\text { search strategy }\end{array}$ & 3 & 75 & $1^{* *}$ & $\ldots$ & 0.85 \\
\hline Initial hits reported & 25 & 49 & 1 & 4 & 0.83 \\
\hline Sites in more than 1 language assessed & 8 & 71 & $\ldots$ & $\ldots$ & 0.86 \\
\hline Interrater reliability for site selection determined & 5 & 67 & $\ldots$ & 7 & 0.71 \\
\hline \multicolumn{6}{|l|}{ Evaluation quality (E-score) } \\
\hline Number of raters reported & 39 & 37 & $\ldots$ & 3†† & 0.71 \\
\hline More than 1 rater & 21 & 45 & 10扭 & 3†† & 0.83 \\
\hline $\begin{array}{l}\text { Interrater reliability figure for evaluation } \\
\text { determined }\end{array}$ & 16 & 57 & 4 & 2 & 0.79 \\
\hline A priori criteria defined for accuracy & 17 & 30 & 2 & 30 & 0.75 \\
\hline A priori criteria defined for completeness & 24 & 16 & $\ldots$ & 39 & 0.87 \\
\hline $\begin{array}{l}\text { Criterion standard for accuracy stated and } \\
\text { different from personal opinion }\end{array}$ & 32 & 17 & $\ldots$ & 30 & 0.97 \\
\hline $\begin{array}{l}\text { Criterion standard for accuracy derived } \\
\text { from clinical guideline or systematic review }\end{array}$ & 15 & 34 & & 30 & 1.00 \\
\hline $\begin{array}{l}\text { Criterion standard for completeness stated } \\
\text { and different from personal opinion }\end{array}$ & 17 & 23 & $\ldots$ & 39 & 0.72 \\
\hline $\begin{array}{l}\text { Criterion standard for completeness derived } \\
\text { from clinical guideline or systematic review }\end{array}$ & 10 & 30 & & 39 & 0.93 \\
\hline \multicolumn{6}{|c|}{ 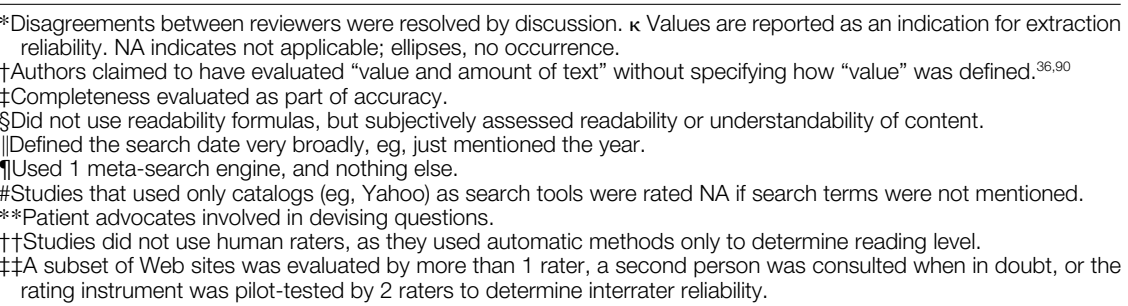 } \\
\hline
\end{tabular}


in Online Table A (http://jama.com) represent the percentages of the maximum score achievable for each study (because some items are not applicable for some studies).

To test construct validity we compared the scores of 5 letters to the editor with the scores of the 74 full publications. As expected, the letters had, on average, lower S-scores (28.8 vs 44.2, $P=.06)$, but similar E-scores (22.4 vs $33.5, P=.45)$. The 7 full articles published in peer-reviewed non-Englishlanguage journals had lower average Escores than articles published in Englishlanguage journals (mean E-score: 18.6 vs 34.8, $P=.09$ ), while their S-scores were similar (mean S-score: 42.3 vs 44.5 , $P=.85)$. While these differences are not significant at a $5 \%$ level, perhaps due to the small study number, the trend goes in the expected direction.

\section{RESULTS \\ Included Studies}

Of 170 articles reviewed, 85 met the inclusion criteria ${ }^{11-95}$ (Online Table A). These constitute 79 distinct studies, as 6 studies were published either in duplicate, ${ }^{26,27,50,51,92,93}$ in a fragmented manner, ${ }^{87,88}$ or were reported both in a peer-reviewed publication and in an unpublished form. ${ }^{14,15,68,69}$ In these cases we pooled the results from the different articles and referred to these as a single study. Table 1 summarizes, and Online Table A lists, all included studies.

Table 2. Overview of Quality Criteria (Other Than Accuracy, Completeness, Readability Level, and Design) Used by 3 or More Studies and Pooled Evaluation Results*

\begin{tabular}{lcccc}
\hline \multicolumn{1}{c}{ Quality Criterion } & $\begin{array}{c}\text { No. of } \\
\text { Studies }\end{array}$ & $\begin{array}{c}\text { Total No. of } \\
\text { Web Sites/Web } \\
\text { Pages Evaluated }\end{array}$ & $\begin{array}{c}\text { Sites/Pages Not } \\
\text { Complying, \%† }\end{array}$ & $\begin{array}{c}\boldsymbol{P} \\
\text { Value }\end{array}$ \\
\hline (a) Disclosure of authorship & 19 & 1636 & $(57.8) \ddagger$ & $<.001$ \\
\hline (b) Disclosure of ownership & 5 & 196 & 1.0 & .28 \\
\hline (c) Sources clear & 4 & 110 & $(44.5) \ddagger$ & $<.001$ \\
\hline (d) Disclosure of sponsorship & 7 & 738 & $(93.4) \S$ & .006 \\
\hline (e) Disclosure of advertising & 3 & 119 & 30.3 & .11 \\
\hline (f) Statement of purpose & 4 & 230 & $(51.7) \ddagger$ & $<.001$ \\
\hline (g) General disclosures & 3 & 298 & $(49.7) \ddagger$ & .001 \\
\hline (h) Date of creation disclosed & 5 & 284 & 83.1 & .56 \\
\hline (i) Date of last update disclosed & 7 & 801 & $(58.8) \S$ & .049 \\
\hline (j) Date of creation or update disclosed & 12 & 1366 & $(63.7) \ddagger$ & $<.001$ \\
\hline (k) Authors' credentials disclosed & 9 & 1030 & $(70.6) \ddagger$ & $<.001$ \\
\hline (l) Credentials of physicians disclosed & 3 & 81 & 97.5 & .90 \\
\hline (m) Authors' affiliation disclosed & 5 & 779 & $(42.5) \ddagger$ & $<.001$ \\
\hline (n) Easy navigation (subjective rating) & 4 & 326 & $(10.1) \ddagger$ & $<.001$ \\
\hline (o) Internal search engine present & 3 & 91 & 79.1 & .16 \\
\hline (p) Links provided & 4 & 238 & $(27.7) \S$ & .005 \\
\hline (q) References provided & 30 & 2135 & $(68.9) \ddagger$ & $<.001$ \\
\hline (r) Balanced evidence & 3 & 182 & $(47.9) \ddagger$ & $<.001$ \\
\hline (s) Writing style appropriate \\
(subjective rating)
\end{tabular}

\section{Quality Criteria and Methods Used to Evaluate Web Sites}

Technical Criteria (T). "Technical" quality criteria were defined as general, domain-independent criteria, ie, criteria referring to the question of how the information was presented or what metainformation was provided. The 24 technical quality criteria most frequently used (TABLE 2) are variations of what could be called "transparency criteria" from the print world, mentioned by Silberg et $\mathrm{al}^{7}$ : authorship, attribution, disclosure, and currency. While the latter is strictly speaking a dimension of accuracy, almost all studies sought for provision of a date of creation or last update (rather than actual currency of the content), which is a technical criterion.

Design (D). Fifteen studies also evaluated subjective design features such as the visual aspect of the site or layout, but only a few studies reported results (ONLINE TABLE B), presumably because of their subjectivity and low reliability. For example, Gillois et al ${ }^{39}$ used a visual analog scale to assess the quality of visual presentation and of the interface, but noted high interobserver variability. Stausberg et $\mathrm{al}^{81}$ report a $\kappa$ of 0.08 when evaluating navigation, and 0.23 when evaluating layout. Speed, browser compatibility, and presence of a search engine were considered technical criteria.

Readability (R). Eleven studies used readability formulas to establish the reading level of a document based on the complexity and length of words and sentences (Online Table B). Nine studies used the Flesch-Kincaid (FK) Grade Level Index. Other formulas used include the SMOG Readability Formula, the Fry Readability Graph, the Gunning-Fog formula, and the Lexile Framework. As different formulas yield different reading levels for the same document, and as authors use different cutoffs, the results cannot be pooled, but studies suggest that reading levels are frequently too high (Online Table B). ${ }^{65}$

Using reading formulas has limitations, as readability scores do not reflect other factors that affect comprehension such as frequency and explanation of medical jargon, writing style 
(use of active voice, nonpatronizing language, motivational messages, tone/ mood, how it relates to the audience), or use of culturally specific information. Few studies analyzed these important but subjective aspectsOermann and Wilson ${ }^{66}$ discussed some of these parameters, Fitzmaurice and Adams ${ }^{35}$ scored the writing style, and Wilson et $\mathrm{a}^{94}$ examined the cultural sensitivity of the documents to various ethnic groups using Bloch's Ethnic/ Cultural Assessment Tool. None of the studies conducted comprehension tests with actual consumers or used judgments of literacy experts.

Accuracy (A). Accuracy can be defined as the degree of concordance of the information provided with the best evidence or with generally accepted medical practice. Alternative terms used for the concept of "accuracy" include "reliability" ${ }^{151}$ or "conventionality of information." ing accuracy "partially," because authors claimed to have evaluated "value and amount of text" without further specifying how they define "value." 36,90

Authors who appraised the accuracy and/or comprehensiveness could either define clear criteria beforehand (a priori) or extract information from the Web first and then check these claims against the literature (a posteriori). Thirty studies assessed accuracy a posteriori, and only 19 a priori (Online Table A). Studies defining elements a priori varied considerably in the granularity and specificity of the items defined in advance: for example, 1 study stated that "paracetamol should be given in a dose of 10 to $15 \mathrm{mg} / \mathrm{kg}$ every 4 hours," ${ }^{51}$ while others just predefined broad keywords that should be mentioned, eg, "oestrogen."75

Accuracy ideally should be defined using the best available evidence. ${ }^{5}$ Fourteen studies used evidence-based guidelines or systematic reviews to define elements a priori and 1 study used a guideline as the criterion standard a posteriori. Eleven studies used primary literature for a posteriori comparison; however, with 1 exception ${ }^{89}$ these studies did not provide details on how and what lit- erature was screened, leaving open the possibility that some authors did not actually search the literature, but just compared information against their own knowledge of the literature. Textbooks or expert consensus were used as the criterion standard in 3 a priori and in 3 a posteriori studies. ${ }^{29,54,55,64,70,84}$ The remaining studies used unclear sources or the personal opinion of the author as the a priori (2 studies) or a posteriori (15 studies) criterion standard.

Completeness/Comprehensiveness/ Coverage/Scope (C). Several methods were used to evaluate "completeness," "comprehensiveness," "coverage," or "scope." Most authors" calculated a proportion of a priori-defined elements covered by a Web site or reported the proportion of Web sites that mentioned all key elements (eg, from a clinical guideline). Willems and Bouvy ${ }^{92,93}$ used a 5-point scale to evaluate completeness. One study ${ }^{11}$ evaluated "balance," eg, whether the adverse effects and contraindications as well as the advantages of a drug are presented, but detailed subcriteria were not made explicit. The Soot score ${ }^{13,46,58,79}$ addresses completeness by measuring coverage of topic areas defined a priori, weighting some areas as being more important than others.

While 19 studies evaluated completeness as a distinct entity, 21 other studies evaluated completeness as an integral part of accuracy (marked "AC" in Online Table A). For example, Impicciatore et a ${ }^{51}$ reported that only 4 of 44 Web sites "adhered closely to the guidelines," implying that these sites were both accurate and complete, whereas Davison $^{27}$ only assessed the accuracy of statements made on the site against the respective statement in the guideline without requiring that all recommendations from nutritional guidelines appear on the Web site. While it is possible to evaluate accuracy without demanding completeness, studies in which authors just prepared checklists for completeness sometimes raise the question as to how and to what extent

*References 12-15, 22, 29, 35, 37, 42, 44-46, 50, 51, 54-56, 58, 59, 70, 75, 78, 79, 85, 92, 93, 95. accuracy has been evaluated. ${ }^{29,35,54,55,75}$ For example, the Soot ${ }^{79}$ score is a weighted checklist giving points for each broad topic covered by the site (such as "treatment options"), but does not specify whether topics were merely present or absent or if they were evaluated for accuracy.

Of the 19 studies that evaluated completeness as a distinct entity, 5 studies used an external source a priori to define elements: 2 used evidence-based guidelines, 2 used primary literature, and 1 used a textbook. The remaining studies used unclear sources or the personal opinion of the author, either a priori (7 studies) or a posteriori ( 7 studies).

\section{Score Systems}

Twenty-two studies $\uparrow$ used a composite score system, most frequently the Soot score, ${ }^{13,46,58,79}$ for adherence to quality criteria. Two studies ${ }^{38,87}$ used DISCERN ${ }^{96}$ and another used Suitability Assessment of Materials (SAM), ${ }^{65}$ both described by their developers as "validated" instruments to assess printed patient education material; however, none of these have been validated in a way such that a higher score would predict better health outcomes or consumer satisfaction.

\section{Quality of Studies}

The quality scores for each study are shown in Online Table A. Out of the 79 studies, 49 received an S-score and an E-score of 50 or less, indicating that both search strategy and evaluation were not well reported or rigorous. However, of the 31 studies using more than 1 rater, 20 made efforts to ascertain the withinstudy reliability of their instruments, which is in contrast to what has been criticized in a previous study about Webbased instruments. ${ }^{97}$

\section{Study Conclusions and Study Quality}

Most studies (55 [70\%]) concluded that quality is a problem on the Internet $(\kappa$

†References 11, 13-15, 23, 31, 35, 36, 38, 42-44, 46, 58, 59, 70, 72, 74, 75, 78, 79, 87, 90 . 
for coding conclusions, 0.88). Seventeen $(21.5 \%)$ were neutral. Only 7 (9\%) came to a more positive conclusion, none of which used evidence-based guidelines as a criterion standard. The mean S-score of the positive studies was significantly lower than that of the negative studies (29.4 vs $45.0 ; P=.02$ ), as was the E-score ( 15.6 vs $37.9 ; P=.04)$, indicating that the more enthusiastic studies used a less rigorous search and evaluation strategy than did negative studies. In a logistic regression model with both scores as predictive variables and the study conclusion "positive/negative" as the dependent variable, the odds ratio (OR) for S-score is 0.929 (95\% confidence interval [CI], 0.871-0.991; $P=.02)$, ie, for each additional S-score percentage point the odds to reach a positive conclusion decreases by $7.1 \%$; the OR for E-score is 0.938 (95\% CI, 0.884$0.996 ; P=.04)$, ie, for each additional Escore percentage point the odds for a positive conclusion decreases by $6.2 \%$.

When studies evaluated accuracy, the proportions of inaccurate Web sites depended on the level of evidence used as a criterion standard: studies that didn't report the criterion standard or that used personal opinion found an average of $15.4 \%$ of Web sites inaccurate; those using literature, textbooks, or expert consensus, $35.3 \%$; and those using clinical guidelines, $38.3 \%$. In an ordinal logistic regression model, the reported proportions of inaccurate Web sites were significantly associated with the $3 \mathrm{lev}$ els of evidence used by authors as criterion standard $(P<.001)$.

Even if authors had similar results, they sometimes interpreted these differently. For example, 3 studies found that about $5 \%$ of cancer Web sites provided inaccurate information, but these results were interpreted as being "of concern," 16 "encouraging," 76 or even "reassuring." 46 In at least 1 case investigators reviewed the same topic area, but arrived at opposite conclusions. ${ }^{28,75}$

\section{COMMENT}

We reviewed 79 studies in which authors evaluated a total of 5941 Web sites and 1329 Web pages, and reported 408 evaluation results for 86 distinct quality criteria (Online Table B).

\section{Content Quality}

In our review, most authors who evaluated content found significant problems, criticizing lack of completeness, difficulty in finding high-quality sites, and lack of accuracy, in particular if "accuracy" also implied "completeness."

Five of eight studies reporting results on completeness found that around $90 \%$ of Web sites were "incomplete" (Online Table B). However, completeness as a requirement has questionable validity from the perspective of the user or the public health researcher. First, too much information may overburden users. Web sites may deliberately and with good reason focus on a single topic in-depth rather than aiming for comprehensiveness. Second, in contrast to printed educational material, a single Web page or Web site is part of a universe of information: a topic not covered by one Web page or site may be covered by another (perhaps linked) Web page. Consumers will usually search across different Web sites when looking for specific health information. ${ }^{98} \mathrm{Me}$ chanical comparison of elements from a guideline with elements covered by a single Web site without taking into account the context and purpose of the site or exploring links to other sites is of limited use. Perhaps a better approach would be to evaluate whether materials cover the topics they claim to be discussing $^{96,99}$ and if they are balanced.

\section{Comparisons Across Studies}

Prevalence figures of inaccurate Web sites differ across different domains, eg, diet and nutrition sites $\left(45.5 \%{ }^{26}\right.$ and $88.9 \%{ }^{64}$ inaccurate information) vs cancer sites (4\% for prostate cancer, ${ }^{46} 5.1 \%$ for breast cancer, ${ }^{76} 9 \%$ for Englishlanguage and 4\% for Spanish-language breast cancer documents, ${ }^{14} 6 \%$ for testicular cancer ${ }^{46}$ or $6.2 \%$ for Ewing Sarcoma $\left.^{16}\right)$. While such prevalence figures may suggest that diet information on the Web is of poorer quality than cancer information, unadjusted comparisons across studies have to be made with care, as at least 3 potential confounders should be considered.

First, results heavily depend on the rigor of the methodology used: studies that used personal opinion as a criterion standard found fewer inaccurate Web sites and more often came to a positive conclusion than studies using more rigorous criteria.

Second, many studies use the terms "Web site" and "Web page" interchangeably, making comparisons difficult.

Third, different and often poorly described sampling and selection strategies were used. While in theory a truly random sample of Web sites could be identified (by choosing random Internet protocol [IP] addresses ${ }^{100}$ ), this approach is not practical for identifying Web sites for a given topic. Thus, all studies used search engines, catalogs, or lists of popular Web sites. However, the choice of the search strategy may greatly confound the results. Most studies mimicked how consumers would search (although only 3 involved actual consumers), hand-selecting popular sites. As there is no consensus and little research on how a typical consumer searches, ${ }^{98}$ studies used various strategies, mostly picking the top-ranked results from a search engine. As many search engines can rank the better sites first, the search tool could influence the results. Moreover, even the same search engine may give a different result if different sampling strategies (ie, which sites are picked) are used. For example, Suarez-Almazor et $\mathrm{al}^{83}$ showed that, in the Webcrawler search engine, the first 20 ranked hits are more relevant, have less financial interests, contain less alternative therapies, and are more often nonprofit organizations, than sites ranked lower. Moreover, the selection of search terms may critically determine which Web sites are retrieved. For example, using the term "coronary heart disease," Eachus ${ }^{31}$ found only 2 sites (among 110) provided by lay people. His conclusion that "the concern that the Internet would be a major source of lowquality health information, particularly that provided by unqualified members of the lay public, is not sup- 
ported by [our] findings" may be confounded by the choice of search terms, as lay people might not necessarily use terms such as "coronary heart disease." Who devises the search strategy and conducts the search can also affect the quality of the retrieved sites. For example, in a comparison of results of a search devised by doctors with a search devised by information experts, Groot et $\mathrm{al}^{43} \mathrm{ob}-$ served differences in the credibility and accuracy scores of the retrieved samples.

\section{Comparison With Other Media}

The quality of Web sites should be interpreted in the larger context of information in other media to determine whether the Web is "the beginning of an epidemic of misinformation or nothing more than a variation of what is endemic." Many of the shortcomings detected likely are not specific to the Web and are also present in other media. For example, 2 of the 4 "erroneous information" elements found on 65 Web pages identified by Biermann et $\mathrm{al}^{16}$ were found in the online version of the Encyclopaedia Britannica, which probably has the same inaccuracies in the printed edition. This issue, and the relatively low prevalence $(6.2 \%)$ of inaccurate information, was generally ignored when this study was widely quoted in the lay media as evidence that the "Internet can be a quick link to bad health information." 101

Studies assessing information in traditional media also frequently report high prevalences of inaccurate or incomplete information. In an early study, authors found $70 \%$ of health information broadcast on television to be inaccurate, misleading, or both. ${ }^{102}$ In another study, authors rated as inaccurate $76 \%$ of the information about oral hygiene from television, 53\% from magazines, and $12 \%$ from newspapers. ${ }^{103}$ Another study of the popular press found $20 \%$ of the information on oral cancer to be a "mix of accurate and inaccurate information." 104 The proportion of inaccurate press reports on healthy eating was found to be $55 \%$ in free advertising newspapers, $28.9 \%$ in lifestyle magazines, $29.9 \%$ in general interest magazines,
$17.5 \%$ in health magazines, and $14.1 \%$ in newspapers. ${ }^{105}$ In another study, $50 \%$ of the advice in newspaper advice columns was rated inappropriate, with critical issues only partially covered or not covered at all in $76 \%$ of the articles, and $58 \%$ were rated unsafe or potentially dangerous. ${ }^{106}$ Inquiries by telephone to libraries yielded a $3.6 \%$ rate of inaccurate information. ${ }^{107}$

The perceived quality problem on the Internet is not restricted to the health sector: a study investigating the quality of general scientific information found that $10 \%$ to $34 \%$ was inaccurate, $20 \%$ to $35 \%$ was misleading, and $48 \%$ to $90 \%$ was unreferenced. ${ }^{108}$

Very few studies in our sample directly compared Internet information with information found elsewhere. One study ${ }^{35}$ evaluated both printed and Webbased patient education materials, concluding that "there was no significant difference between the ranges of scores [incorporating content, writing style, design, and readability] for Internet and non-Internet leaflets"; however, subjectively authors felt that "the overall quality of the Internet leaflets was more variable and the information less comprehensive." Two studies compared the readability of Internet information with the readability of printed information. One study ${ }^{33}$ concluded that SMOG readability levels of Internet information were significantly higher compared with other (printed) patient information materials; the other study ${ }^{65}$ observed no differences in the proportion of patient information written above the 9th grade level, but $87.5 \%$ of Web information materials vs only $14.3 \%$ of printed patient information, were deemed unsuitable based on the Suitability Assessment of Materials score (however, as the $8 \mathrm{Web}-$ based patient education materials came from only 2 different Web sites, this result may not be representative). We identified only 1 study that compared the accuracy of advice obtained on the Internet (in a pharmacy newsgroup, hence this study was excluded from this review) with advice obtained in the real world (from drug information centers). ${ }^{109}$
In summary, the prevalence figures of inaccurate or incomplete Web information reported by the studies in this review are difficult to interpret or compare, are unlikely to be representative or generalizable, and must also be considered against the background of imperfect consumer health information in other media.

\section{Presentation Quality}

The presentation criteria evaluated by most investigators are considered to be quality criteria because: (1) their presence is deemed ethical according to several codes of conduct for Web publishing ${ }^{110-114}$ (eg, transparency and accountability criteria, such as disclosure of authorship); (2) they help to create context and to avoid misunderstandings (eg, disclosure of sponsorship, purpose); (3) they empower users to select the information that is best for them in their individual situation (eg, disclosure of target audience); (4) they empower users to validate the information themselves (eg, references, contact addresses); or (5) they may influence the accessibility of information or effectiveness of communication (eg, search capabilities, speed, design). In addition, several authors have attempted to establish whether technical criteria or other site characteristics may be used as predictors for content quality, ${ }^{11,42,47,58,87,91}$ but the results have been conflicting and inconclusive. A number of studies found, perhaps unsurprisingly, that the length of a document is correlated with better content scores. ${ }^{42,58,87} \mathrm{~A}$ few studies suggest that the source may be a predictor for content quality, with commercial sites often scoring lower than academic sites ${ }^{59,74,75}$ but the way in which content is evaluated may also influence this relationship. Other technical criteria influenced by the source include references, which are more often found on Web sites targeting medical professionals, ${ }^{23}$ on academic ${ }^{46,79}$ or educational ${ }^{89}$ sites, or on sites owned by organizations. ${ }^{42}$ Individual authors often are not disclosed on government sites ${ }^{14}$ or sites of organizations and drug companies. ${ }^{42}$ Given these complex relation- 
ships, it seems unlikely that a simple scoring system could be developed that predicts content quality across domains and site populations.

As with content criteria, the ability to compare or pool results across studies is impeded by wide variations in sampling strategies, methods, and operational definitions even for the same quality criteria (eg, what constitutes "attribution"). Moreover, there is no consensus on the unit of evaluation (eg, should the update cycle be published on each Web page, or is a site-specific disclosure sufficient) or granularity with which information should be provided (eg, is it sufficient to post the year of last update, or should the exact date be given).

Despite this lack of consensus, some quality criteria are consistently given (eg, "ownership disclosure," with 99\% of sites providing information) or not given (eg, "credentials of physicians not disclosed," with $97.5 \%$ not complying) (Table 2).

As with content criteria, presentation criteria should be put into context by comparison with non-Web-based information. While in our study $64 \%$ of Web sites failed to provide a date of update, investigators evaluating printed patient leaflets have found that $53 \%,{ }^{35}$ or, in another study, one-third, ${ }^{115}$ did not include publication dates.

\section{Omissions}

Since most authors used criteria derived from the print world, ${ }^{7}$ we noted important omissions concerning Webspecific criteria. For example, very few studies evaluated the privacy policy or the possibility to encrypt confidential information, and few studies checked whether the target audience or the target country (which is important in a global medium ${ }^{116}$ ) were clearly disclosed. None of the studies tested usability $^{117}$ or accessibility (eg, compliance with guidelines of the Web Accessibility Initiative, ascertaining that the site is available to people with disabilities or with low-end technology), and only 1 study checked whether metadata were provided, ${ }^{76}$ which could greatly enhance the consumer's ability to select and filter information. ${ }^{6}$

\section{Measuring Progress of Health Communication on the Web}

Among the public health objectives of the US Department of Health and Human Services is to "increase the proportion of health-related World Wide Web sites that disclose information that can be used to assess the quality of the site." ${ }^{118}$ How progress in this area might be achieved or evaluated is an open question. A metaanalysis of cross-sectional studies is one possible way, but one must take into account the different methods used (or the methods must be standardized) before meaningful conclusions can be drawn. Longitudinal studies could be used to assess changes over time, using a consistent methodology either to identify and assess Web sites for a given topic (with the caveat that observed changes may be changes in the ability of users to find better sites, ie, improvements in search engine technology to rank better sites first) or to follow up a cohort of Web sites. Two studies have attempted a longitudinal approach, with conflicting results; one observed an improvement, and the other a deterioration, in quality. ${ }^{36,57,90}$ The third possibility is to promote among site developers the use of machine-processable disclosure statements as Web site labels (meta-data) ,${ }^{6,119}$ which would allow automatic tracking and analysis of the proportion and characteristics of Web sites making such disclosure statements. This would also facilitate the development of intelligent systems able to guide users to trustworthy Web sites. ${ }^{120}$

\section{Conclusion}

The epidemiology of consumer health information on the Web is an emerging research discipline at the intersection of medical informatics and public health. Many descriptive, crosssectional studies have attempted to draw attention to perceived "outbreaks" of misinformation on the Web by estimating the proportion or prevalence of inadequate health informa- tion. However, the individual's risk ( $\mathrm{R}$ ) of encountering an inadequate site on the Web is a function of both the proportion of inadequate information on the Web (P) and the inability (I) of the individual (or his tools) to filter the inadequate sites. Since studies usually report R, but not I, we cannot infer $\mathrm{P}$, or adjust study results to make them comparable across domains or time. Even if we could know $\mathrm{P}$, we would still not know how this measurement of "true" misinformation on the Web translates into health outcomes or critical incidents in a population. On an individual level, $\mathrm{R}$ can be reduced by improving the ability of the user to locate trustworthy sites or to filter the inadequate ones. Public e-health interventions such as MedCERTAIN ${ }^{121}$ therefore strive to reduce $\mathrm{P}$ and I by increasing, for example, the proportion of health information providers making disclosure statements ${ }^{119}$ and by empowering consumers to identify trusted sites through educational and technological innovations, including the possibilities of the semantic Web. ${ }^{120}$

Given the difficulty in interpreting descriptive studies without control or comparison groups, future studies should use analytic rather than descriptive approaches to investigate the relationship between quality markers and other variables, including outcomes, or to compare different Web site populations or media. Such studies are urgently needed to help in the ongoing process to develop methods and instruments to guide consumers to quality information and to identify factors that can be assessed to predict favorable patient outcomes.

Finally, studies evaluating content should also harness the potential of the Web as a source for qualitative data ${ }^{122}$ : rather than getting bogged down by the question of how much information is inaccurate, one could analyze where and why gaps exist between evidencebased medicine and health information on the Internet, which may elicit a wealth of valuable data that may inform priorities for research, health communication, and education. 
Author Contributions: Study concept and design: Eysenbach, Powell.

Acquisition of data: Eysenbach, Powell, Sa. Analysis and interpretation of data: Eysenbach, Powell, Kuss.

Drafting of the manuscript: Eysenbach.

Critical revision of the manuscript for important intellectual content: Eysenbach, Powell, Kuss, Sa.

Statistical expertise: Eysenbach, Kuss.

Obtained funding: Eysenbach.

Administrative, technical, or material support: Sa.

Study supervision: Eysenbach.

Related Information: Online tables available at http:/ jama.com.

Funding/Support: Dr Eysenbach was partly funded by the European Union under the Action Plan for Safer Use of the Internet (http://www.saferinternet.org) MedCERTAIN Project (http://www.medcertain.org). Mr Powell is funded by the NHS (South East) Research and Knowledge Management program.

\section{REFERENCES}

1. Eysenbach G. Consumer health informatics. BMJ. 2000;320:1713-1716.

2. Coiera E. Information epidemics, economics, and immunity on the Internet. BMJ. 1998;317:1469-1470.

3. Jadad AR, Gagliardi A. Rating health information on the Internet. JAMA. 1998;279:611-614.

4. Kim P, Eng TR, Deering MJ, Maxfield A. Published criteria for evaluating health related web sites: review. BMJ. 1999;318:647-649.

5. Wyatt JC. Commentary: measuring quality and impact of the World Wide Web. BMJ. 1997:314:1879. 1881.

6. Eysenbach G, Diepgen TL. Towards quality management of medical information on the internet. BMJ. 1998;317:1496-1500.

7. Silberg WM, Lundberg GD, Musacchio RA. Assessing, controlling, and assuring the quality of medical information on the Internet. JAMA. 1997;277:12441245.

8. Landis RJ, Koch GG. The measurement of observer agreement for categorical data. Biometrics. 1977;33: 159-174.

9. Bohning D, Dammann UP. The application of methods of meta-analysis for heterogeneity modeling in quality control and assurance. In: Schulze R, Holling $\mathrm{H}$, Bohning D, eds. Meta-analysis: New Developments and Applications in Medical and Social Sciences. Seattle, Wash: Hogrefe \& Huber. In press.

10. Oxman AD, Guyatt GH. Validation of an index of the quality of review articles. J Clin Epidemiol. 1991; 44:1271-1278

11. Abbott VP. Web page quality: can we measure it and what do we find? J Public Health Med. 2000;22: 191-197.

12. Armstrong K, Schwartz JS, Asch DA. Direct sale of sildenafil (Viagra) to consumers over the Internet. NEng/ J Med. 1999;341:1389-1392.

13. Beredjiklian PK, Bozentka DJ, Steinberg DR, Bernstein J. Evaluating the source and content of orthopaedic information on the Internet. J Bone Joint Surg Am. 2000;82:1540-1543.

14. Berland GK, Elliott MN, Morales LS, et al. Health information on the Internet: accessibility, quality, and readability in English and Spanish. JAMA. 2001;285: 2612-2621

15. Berland GK, Morales LS, Elliott MN, et al. Evaluation of English and Spanish Health Information on the Internet. Santa Monica: RAND/California HealthCare Foundation; 2001. Available at: http://www.rand.org /publications/documents/interneteval/. Accessibility verified April 25, 2002.

16. Biermann JS, Golladay GJ, Greenfield ML, Baker $\mathrm{LH}$. Evaluation of cancer information on the Internet. Cancer. 1999:86:381-390.

17. Bloom BS, Iannacone RC. Internet availability of prescription pharmaceuticals to the public. Ann Intern Med. 1999:131:830-833.

18. Bogenschutz MP. Drug information libraries on the Internet. J Psychoactive Drugs. 2000;32:249-258.

19. Boyer EW, Shannon M, Hibberd PL. Web sites with misinformation about illicit drugs. N Eng/ J Med. 2001; 345:469-471.

20. Breul H, Boue L, Martin A. Panorama des ressources documentaires hospitaliéres françaises sur Internet [Overview of Internet information resources of interest to French hospitals]. Semaine des Hopitaux. 1999;75:257-262.

21. Butzke I, Kramer KL. Orthopadie im World Wide Web: Universitats-Homepages der G7-Staaten. Z Orthop Ihre Grenzgeb. 2000;138:413-418.

22. Bykowski JL, Alora MB, Dover JS, Arndt KA. Accessibility and reliability of cutaneous laser surgery information on the World Wide Web. J Am Acad Dermatol. 2000;42:784-786.

23. Chen LE, Minkes RK, Langer JC. Pediatric surgery on the Internet. J Pediatr Surg. 2000;35:11791182

24. Corpron CA, Lelli JL Jr. Evaluation of pediatric surgery information on the Internet. J Pediatr Surg. 2001; 36:1187-1189.

25. D'Alessandro DM, Kingsley $P$, Johnson-West J. The readability of pediatric patient education materials on the World Wide Web. Arch Pediatr Adolesc Med. 2001:155:807-812.

26. Davison $\mathrm{K}$. The quality of dietary information on the World Wide Web. J Can Dietetic Assoc. 1996; 57:137-141.

27. Davison $\mathrm{K}$. The quality of dietary information on the World Wide Web. Clin Perform Qual Health Care. 1997:5:64-66.

28. Diering $\mathrm{CL}$, Palmer $\mathrm{MH}$. Professional information about urinary incontinence on the World Wide Web. J Wound Ostomy Continence Nurs. 2001;28: 55-62.

29. Doupi $P$, van der Lei J. Rx medication information for the public and the WWW: quality issues. Med Inform Internet Med. 1999:24:171-179.

30. Dracos $A$, Seta $M$. Egeszsegugyi informaciok az Interneten laikusoknak: olaszorszagi tapasztalatok. Health information for the lay person on the Internet: a survey of the Italian experience]. Tudomanyos es Muszaki Tajekoztatas. 1998;45:118-120.

31. Eachus P. Health information on the Internet. Int Health Prom Educ. 1999:37:30-33.

32. Ellamushi $H$, Narenthiran $G$, Kitchen ND. Is current information available useful for patients and their families? Ann R Coll Surg Engl. 2001;83:292-294.

33. Estrada CA, Hryniewicz MM, Higgs VB, Collins $C$, Byrd JC. Anticoagulant patient information material is written at high readability levels. Stroke. 2000; 31:2966-2970.

34. Eysenbach G. Online prescribing of sildanefil (Viagra) on the World Wide Web. J Med Internet Res. 1999;1:e10. Available at: http://www.jmir.org/1999 /2/index.htm. Accessibility verified March 25, 2002. 35. Fitzmaurice DA, Adams JL. A systematic review of patient information leaflets for hypertension. J Hum Hypertens. 2000;14:259-262.

36. Frasca D, Malezieux R, Mertens P, Neidhardt JPH, Voiglio EJ. Review and evaluation of anatomy sites on the Internet (updated 1999). Surg Radiol Anat. 2000; 22:107-110.

37. Galimberti A, Jain S. Gynaecology on the Net. J Obstet Gynaecol. 2000;20:297-299.

38. Gillies $M$. Access to the information should be made easier. BMJ. 2000;321:47-48.

39. Gillois $\mathrm{P}$, Colombet I, Dreau H, Degoulet $\mathrm{P}$, Chatellier G. A critical appraisal of the use of Internet for calculating cardiovascular risk. Proc AMIA Symp. 1999: 775-779.

40. Gordon JB, Barot LR, Fahey AL, Matthews MS. The Internet as a source of information on breast augmentation. Plast Reconstr Surg. 2001;107:171-176.
41. Graber MA, Roller CM, Kaeble B. Readability levels of patient education material on the World Wide Web. J Fam Pract. 1999;48:58-61.

42. Griffiths KM, Christensen H. Quality of web based information on treatment of depression: cross sectional survey. BMJ. 2000;321:1511-1515.

43. Groot D, Riet G, Khan KS, Misso K. Comparison of search strategies and quality of medical information of the Internet: a study relating to ankle sprain Injury. 2001;32:473-476.

44. Harmon D, Duggan M, Flynn N. Anaesthesia on the World Wide Web. Anaesthesia. 2000:55:728 729.

45. Hatfield CL, May SK, Markoff JS. Quality of consumer drug information provided by four Web sites. Am J Health Syst Pharm. 1999:56:2308-2311.

46. Hellawell GO, Turner KJ, Le Monnier KJ, Brewster SF. Urology and the Internet: an evaluation of Internet use by urology patients and of information available on urological topics. BJU Int. 2000;86:191-194. 47. Hernández-Borges AA, Macías-Cervi $P$, GasparGuardado MA, Torres-Álvarez de Arcaya ML, RuizRabaza A, Jiménez-Sosa A. Can examination of WWW usage statistics and other indirect quality indicators help to distinguish the relative quality of medical web sites? J Med Internet Res. 1999;1:e1. Available at: http://www.jmir.org/1999/1/e1/index.htm. Accessibility verified March 25, 2002.

48. Hersh WR, Gorman PN, Sacherek LS. Applicability and quality of information for answering clinical ques tions on the Web. JAMA. 1998;280:1307-1308.

49. Hoffman-Goetz L, Clarke JN. Quality of breast cancer sites on the World Wide Web. Can J Public Health 2000;91:281-284.

50. Impicciatore $P$, Pandolfini $C$, Casella $N$, Bonati $M$. Possiamo fidarci delle informazioni sanitarie al pubblico che viaggiano su Internet? I'esempio della ges tione domiciliare della febbre nel bambino. [Reliability of public-oriented health care resources in the World Wide Web: the case of the home management of fever in children]. Ricerca e Pratica. 1997;13:67-75. 51. Impicciatore $P$, Pandolfini $C$, Casella N, Bonati $M$. Reliability of health information for the public on the World Wide Web. BMJ. 1997;314:1875-1879.

52. Jiang YL. Quality evaluation of orthodontic information on the World Wide Web. Am J Orthod Dentofacial Orthop. 2000;118:4-9.

53. Kihlstrom LC. Evaluating pharmacy benefit management information on the Internet. Manag Care Interface. 2001:14:64-68.

54. Latthe PM, Latthe M, Khan KS. Quality of medical information about menorrhagia on the worldwide web. BJOG 2000:107:39-43.

55. Latthe M, Latthe PM, Charlton R. Quality of information on emergency contraception on the internet. Br J Fam Plann. 2000:26:39-43.

56. Latthe PM, Latthe M, Khan KS. Quality of information on female sterilisation on the Internet. $J \mathrm{Ob}$ stet Gynaecol. 2000;20:167-170.

57. Li L, Irvin E, Guzman J, Bombardier A. Surfing for back pain patients. Spine. 2001;26:545-557

58. Libertiny G, Perkins JM, Magee TR, Galland RB. Varicose veins on the internet. Eur J Vasc Endovasc Surg. 2000;20:386-389.

59. Lissman TL, Boehnlein JK. A critical review of internet information about depression. Psychiatr Serv. 2001;52:1046-1050

60. Mallory C. What's on the Internet? services for women affected by HIV and AIDS. Health Care Women Int 1997:18:315-322.

61. Martinez-Lopez JF, Ruiz-Crespo EJ. Internet: calidad de la informacion sobre cirugia [Internet: quality of information available on orthopaedic surgery and traumatology]. Revista de Ortopedia y Traumatologia. 1998;42:469-473.

62. Maugans TA, McComb JG, Levy ML. The internet as a pediatric neurosurgery information resource. Pediatr Neurosurg. 1998;28:186-190. 
63. McClung HJ, Murray RD, Heitlinger LA. The Internet as a source for current patient information. Pediatrics. 1998;101:e2

64. Miles J, Petrie C, Steel M. Slimming on the Internet. J R Soc Med. 2000;93:254-257.

65. Murphy PW, Chesson AL, Berman SA, Arnold CL, Galloway G. Neurology patient education materials. J Neurosci Nurs. 2001;33:99-104

66. Oermann $M H$, Wilson FL. Quality of care information for consumers on the Internet. J Nurs Care Qual. 2000;14:45-54.

67. O'Mahony B. Irish health care Web sites: a review. Ir Med J. 1999:92:334-337.

68. Ogushi Y, Tatsumi H. Research on the Analysis of the Current State of the Provision and Use of Health Information Provided Through a New Technology Medium [in Japanese]. Tokyo, Japan: Health \& Welfare Ministry Research Group; 2000.

69. Tatsumi $\mathrm{H}$, Mitani $\mathrm{H}$, Haruki $\mathrm{Y}$, Ogushi $\mathrm{Y}$ Internet medical usage in Japan. J Med Internet Res. 2001; 3:e12. Available at: http://www.jmir.org/2001/1 /e12. Accessibility verified April 24, 2002.

70. Pandolfini $C$, Impicciatore $P$, Bonati $M$. Parents on the web. Pediatrics. 2000;105:e1.

71. Payne C, Miller K. The quality of footcare information on the Internet. Australas J Podiatr Med. 2000; $34: 63$

72. Peroutka SJ. Analysis of Internet sites for headache. Cephalalgia. 2001;21:20-24.

73. Roberts JR, Spooner SA. Pediatric Internet resources. Arch Pediatr Adolesc Med. 1997;151:592597.

74. Sacchetti $P$, Zvara $P$, Plante MK. The Internet and patient education-resources and their reliability. Urology. 1999;53:1117-1120.

75. Sandvik H. Health information and interaction on the Internet. BMJ. 1999:319:29-32.

76. Shon J, Musen MA. The low availability of metadata elements for evaluating the quality of medical information on the World Wide Web. Proc AMIA Symp. 1999:945-949.

77. Sing A, Salzman JR, Sing D. Problems and risks of unsolicited e-mails in patient-physician encounters in travel medicine settings. J Trav Med. 2001;8: 109.

78. Smith M, Gertz E, Alvarez S, Lurie P. The content and accessibility of sex education information on the Internet. Health Educ Behav. 2000;27:684-694. 79. Soot LC, Moneta GL, Edwards JM. Vascular surgery and the Internet. J Vasc Surg. 1999;30:84-91. 80. Stausberg J, Fuchs J. Die chirurgische Fachabteilung im World Wide Web: Tribut an den Zeitgeist oder Informationsdrehscheibe? [Surgical specialty department in the World Wide Web: tribute to contemporary life style or information network?]. Chirurg. 2000;71:472-477.

81. Stausberg J, Fuchs J, Husing J, Hirche H. Health care providers on the World Wide Web. Med Inform Internet Med. 2001;26:17-24.

82. Stone TW, Jumper JM. Information about agerelated macular degeneration on the Internet. South Med J. 2001:94:22-25.

83. Suarez-Almazor ME, Kendall CJ, Dorgan M. Surfing the Net-information on the World Wide Web for persons with arthritis. J Rheumatol. 2001;28:185191.

84. Tamm EP, Raval BK, Huynh PT. Evaluation of the quality of self-education mammography material available for patients on the Internet. Acad Radiol. 2000; 7:137-141

85. Thompson JM, Howard JE. HMO Web sites. Manag Care Q. 2000;8:33-41.
86. Tu F, Zimmerman NP. It is not just a matter of thics: a survey of the provision of health disclaimers, caveats, and other health-related alerts in consumer health information on eating disorders on the Internet. Int Inf Libr Rev. 2001;32:325-339.

87. Türp JC, Gerds T, Neugebauer S. Myoarthorpathien des Kausystems: Beurteilung der Qualität von Patienteninformationen im Weltweiten Netz. Z Arztl Fortbild Qualitatssich. 2001:95:539-547.

88. Neugebauer S, Türp JC. Vorsicht Internet! Webseiten uber myoarthropathien des kausystems [Attention Internet! Web sites on myoarthropathies of the mastication system]. Schweiz Monatsschr Zahnmed. 2001;111:298-311.

89. Veronin MA, Ramirez $G$. The validity of health claims on the World Wide Web. Am J Health Promot. 2000;15:21-28.

90. Voiglio E, Frasca D, Malezieux R, Moreau S, Ro$\operatorname{dier} M \mathrm{~N}$, Neidhardt JPH. Prospecting and evaluation of the anatomy sites on the internet. Surg Radiol Anat. $1999 ; 21: 65-68$

91. von Danwitz F, Baehring T, Scherbaum W. Verbreitung, Gestaltung und Qualität von Deutschsprachigen World Wide Web Seiten zum Diabetes Mellitus. Düsseldorf, Germany: Deutsches Diabetes Forschungsinstitut; 1999.

92. Willems M, Bouvy ML. Gezondheidsinformatie op Internet: ze adviseren gewoon de spullen die op voorraad zijn. Pharmaceutisch Weekblad. 2001;136:607609.

93. Willems M, Bouvy ML. Gezondheidsinformatie op het internet: de kwaliteit van websites vergeleken. Medisch Contact. 2001;56:673-676.

94. Wilson FL, Baker LM, Brown-Syed C, Gollop C. An analysis of the readability and cultural sensitivity of information on the National Cancer Institute's Web site: CancerNet. Oncol Nurs Forum. 2000:27:14031409.

95. Wright B, Williams C, Partridge I. Management advice for children with chronic fatigue syndrome: a systematic study of information from the Internet. Ir Psychol Med. 1999;16:67-71.

96. Charnock D, Shepperd S, Needham G, Gann R. DISCERN: an instrument for judging the quality of written consumer health information on treatment choices. J Epidemiol Community Health. 1999;53:105-111. 97. Delamothe T. Quality of websites: kitemarking the west wind. BMJ. 2000;321:843-844.

98. Eysenbach G, Köhler $C$. How do consumers search for and appraise health information on the WorldWide-Web? BMJ. 2002;324:573-577.

9. Dalton L, Gartenfeld E. Evaluating printed health information for consumers. Bull Med Libr Assoc. 1981; 69:322-324.

100. Lawrence S, Giles CL. Accessibility of information on the web. Nature. 1999:400:107-109.

101. Internet can be quick link to bad health information. CNN. July 29, 1999. Available at: http://www cnn.com/HEALTH/9907/29/internet.health. Accessibility verified April 25, 2002

102. Smith FA, Trivax G, Zuehlke DA, Lowinger P, Nghiem TL. Health information during a week of television. N Engl J Med. 1972;286:516-520.

103. Frazier PJ, Jenny J, Ostman R, Frenick C. Quality of information in mass media: a barrier to the dental health education of the public. J Public Health Dent. 1974:34:244-257

104. Canto MT, Kawaguchi Y, Horowitz AM. Coverage and quality of oral cancer information in the popular press: 1987-98. J Public Health Dent. 1998; 58:241-247.

105. Institut für Ernährungswissenschaften der Uni- versität Wien. Öterreichischer Ernährungsbericht. Vienna, Austria: Bundesministerium für Arbeit, Gesundheit und Soziales und der Bundesministerin für Frauenangelegenheiten und Verbraucherschutz; 1998 106. Molnar FJ, Man-Son-Hing M, Dalziel WB, et al. Assessing the quality of newspaper medical advice columns for elderly readers. CMAJ. 1999;161:393-395 107. Paskoff BM. Accuracy of telephone reference service in health sciences libraries. Bull Med Libr Assoc. 1991;79:182-188.

108. Allen ES, Burke JM, Welch ME, Rieseberg LH How reliable is science information on the web? $\mathrm{Na}$ ture. 1999:402:722.

109. Seaboldt JA, Kuiper R. Comparison of information obtained from a Usenet newsgroup and from drug information centers. Am J Health Syst Pharm. 1997 54:1732-1735.

110. Risk A, Dzenowagis J. Review of Internet health information quality initiatives. J Med Internet Res. 2001; 3:e28. Available at: http://www.jmir.org/2001/4 /e28

111. Boyer C, Selby M, Scherrer JR, Appel RD. The Health on the Net Code of Conduct for medical and health Websites. Comput Biol Med. 1998;28:603610.

112. Hi-Ethics Group. Health Internet Ethics: Ethical Principles For Offering Internet Health Services to Consumers. 2000. Available at: http://www.hiethics.org /Principles/. Accessibility verified March 25, 2002.

113. e-Health Ethics Initiative. e-Health Code of Ethics. J Med Internet Res. 2000;2:e9. Available at: http:// www.jmir.org/2000/2/e9/. Accessibility verified March 25, 2002

114. Winker MA, Flanagin A, Chi-Lum B, et al. Guidelines for medical and health information sites on the Internet. JAMA. 2000;283:1600-1606

115. Coulter A, Entwistle V, Gilbert D. Sharing decisions with patients: is the information good enough? BMJ. 1999;318:318-322.

116. Eysenbach G, Diepgen TL. Labeling and filtering of medical information on the Internet. Methods Inf Med. 1999:38:80-88.

117. Nielsen J. Usability Engineering. San Diego, Calif Morgan Kaufmann; 1993.

118. US Department of Health and Human Services. Healthy People 2010: Understanding and Improving Health. 2nd ed. Washington, DC: Office of Disease Prevention and Health Promotion, US Dept of Health and Human Services; 2000. Publication 017-00100547-9. Available at: http://www.health.gov /healthypeople/document/. Accessibility verified March 25,2002

119. Eysenbach G, Köhler C, Yihune G, Lampe K, Cross $P$, Brickley D. A metadata vocabulary for self- and thirdparty labeling of health web-sites. Proc AMIA Annu Fall Symp. 2001:169-173.

120. Eysenbach G. An ontology of quality initiatives and a model for decentralized, collaborative quality management on the (semantic) World-Wide-Web Med Internet Res. 2001;3:e34. Available at: http:// www.jmir.org/2001/4/e34. Accessibility verified April 24, 2002

121. Eysenbach $G$, Köhler $C$, Yihune $G$, Lampe $K$, Cross $P$, Brickley D. A framework for improving the quality of health information on the world-wide-web and bettering public (e-)health. Medinfo2001, Proceedings of the Tenth World Congress on Medical Informat ics, London, England, September 2001. Amsterdam, Holland: IOS Press; 2001:1450-1454.

122. Eysenbach G, Till JE. Ethical issues in qualitative research on Internet communities. BMJ. 2001;323: 1103-1105 
Online Table A. Included Studies Assessing Quality of Health Information on Web Sites or Web Pages*

\begin{tabular}{|c|c|c|c|c|c|c|c|c|}
\hline Study, Year & $\begin{array}{l}\text { Period } \\
\text { Conducted }\end{array}$ & $\begin{array}{l}\text { Study Domain, } \\
\text { Population }\end{array}$ & $\begin{array}{c}\text { Evaluation Method and } \\
\text { Criteria }\end{array}$ & $\begin{array}{l}\text { No. of } \\
\text { Raters }\end{array}$ & $\begin{array}{c}\text { Interrater } \\
\text { Reliability } \\
\text { Determined? }\end{array}$ & S-score & E-score & $\begin{array}{c}\text { Authors' } \\
\text { Conclusion }\end{array}$ \\
\hline Abbott, ${ }^{11} 2000$ & $\begin{array}{l}\text { NR (accepted } \\
\text { October 1999) }\end{array}$ & $\begin{array}{c}40 \text { Sites providing } \\
\text { information on } \\
\text { MMR vaccine }\end{array}$ & $\begin{array}{l}\text { A (a posteriori, "reflects the } \\
\text { most current research," } \\
\text { based on MEDLINE } \\
\text { searches, textbooks, and } \\
\text { an expert consultation) } \\
\text { C ("balance: stating side } \\
\text { effects and } \\
\text { contraindications along } \\
\text { with advantages") } \\
\text { T (16 items, partly referring to } \\
\text { "page aesthetics") } \\
\text { R (Flesch Reading Ease } \\
\text { Score, calculated using } \\
\text { WordPerfect v8) } \\
\text { D (use of relevant graphics; } \\
\text { overall aesthetics rating) } \\
\text { S (author is "recognized } \\
\text { authority" and "cualified to } \\
\text { publish the document") }\end{array}$ & 1 & No & 38 & 30 & Negative \\
\hline $\begin{array}{c}\text { Armstrong } \\
\text { et al, }{ }^{12} \\
1999\end{array}$ & $\begin{array}{l}\text { April 14-May 7, } \\
1999\end{array}$ & $\begin{array}{l}77 \text { Sites selling } \\
\text { sildanefil } \\
\text { without } \\
\text { requiring a } \\
\text { prescription or } \\
\text { a visit to a } \\
\text { physician }\end{array}$ & $\begin{array}{l}\text { C (a priori, checked for } \\
\text { example whether sites } \\
\text { required or offered medical } \\
\text { evaluation, what } \\
\text { information was required } \\
\text { from consumers' medical } \\
\text { history [5 items], what } \\
\text { information was provided } \\
\text { about sildanefil [5 items]) } \\
\text { T (eg, disclaimers and } \\
\text { warnings present, } \\
\text { qualification of physician } \\
\text { provided) }\end{array}$ & $1 ?$ & No & 50 & 14 & Negative \\
\hline $\begin{array}{l}\text { Beredjiklian } \\
\text { et al, }{ }^{13} \\
2000\end{array}$ & $\begin{array}{l}\text { NR (published } \\
\text { November } \\
\text { 2000) }\end{array}$ & $\begin{array}{l}175 \text { Sites } \\
\text { providing } \\
\text { information on } \\
\text { carpal tunnel } \\
\text { syndrome }\end{array}$ & $\begin{array}{l}\text { "Soot score": } \\
\text { A (therapy classified as } \\
\text { "conventional, } \\
\text { unconventional, or } \\
\text { misleading," a posteriori, } \\
\text { compared against } \\
\text { "textbooks and literature") } \\
\text { C (31 items with different } \\
\text { weights, leading to an } \\
\text { "information score" with } \\
100 \text { points maximum) } \\
\text { T (authorship identifiable) }\end{array}$ & 2 & Yes & 38 & 50 & Negative \\
\hline $\begin{array}{l}\text { Berland } \\
\quad \text { et al, }{ }^{14,15} \\
2001\end{array}$ & $\begin{array}{c}\text { October 18-30, } \\
2000+ \\
\text { November } \\
6-13,2000\end{array}$ & $\begin{array}{l}18 \text { English and } 7 \\
\text { Spanish sites } \\
\text { covering } \\
\text { breast cancer, } \\
\text { childhood } \\
\text { asthma, } \\
\text { depression, } \\
\text { obesity }\end{array}$ & $\begin{array}{l}\text { A (100 a priori elements on } \\
\text { 3-point scale ["mostly } \\
\text { incorrect," "mostly } \\
\text { correct,"'"completely } \\
\text { correct"]) } \\
\text { C (100 a priori elements rated } \\
\text { on 3-point scale [“not } \\
\text { covered," "'minimally } \\
\text { covered," "more than } \\
\text { minimally covered") } \\
\text { T (2 items: authors and } \\
\text { affiliations and credentials } \\
\text { disclosed, date material } \\
\text { created or updated) } \\
\text { R (Fry Readability Graph } \\
\text { (FRG), SMOG grading } \\
\text { formula (English only), } \\
\text { Lexile Framework, } \\
\text { Flesch-Kincaid) }\end{array}$ & $\begin{array}{r}\text { 3-4 (AC) per } \\
\text { condition }\end{array}$ & Yes & 62 & 95 & Neutral \\
\hline
\end{tabular}


Online Table A. Included Studies Assessing Quality of Health Information on Web Sites or Web Pages* (cont)

\begin{tabular}{|c|c|c|c|c|c|c|c|c|}
\hline Study, Year & $\begin{array}{l}\text { Period } \\
\text { Conducted }\end{array}$ & $\begin{array}{l}\text { Study Domain, } \\
\text { Population }\end{array}$ & $\begin{array}{l}\text { Evaluation Method and } \\
\text { Criteria }\end{array}$ & $\begin{array}{l}\text { No. of } \\
\text { Raters }\end{array}$ & $\begin{array}{c}\text { Interrater } \\
\text { Reliability } \\
\text { Determined? }\end{array}$ & S-score & E-score & $\begin{array}{l}\text { Authors' } \\
\text { Conclusion }\end{array}$ \\
\hline $\begin{array}{l}\text { Biermann et } \\
\quad \mathrm{al}^{1{ }^{16}} 1999\end{array}$ & $\begin{array}{l}\text { NR (submitted } \\
\text { December } \\
\text { 1998) }\end{array}$ & $\begin{array}{c}371 \text { (170 relevant) } \\
\text { pages about } \\
\text { Ewing } \\
\text { Sarcoma, } 65 \\
\text { (or } 70) \\
\text { evaluated for } \\
\text { accuracy }\end{array}$ & $\begin{array}{l}\text { A (a posteriori, compared } \\
\text { against textbook) } \\
\text { T (reference source listed) }\end{array}$ & 2 & No & 50 & 43 & Negative \\
\hline $\begin{array}{l}\text { Bloom and } \\
\text { lanna- } \\
\text { cone, }^{17} \\
1999\end{array}$ & $\begin{array}{l}\text { February-March } \\
\quad 1999\end{array}$ & $\begin{array}{l}46 \text { Web sites } \\
\text { offering } \\
\text { prescription } \\
\text { drugs to } \\
\text { consumers }\end{array}$ & $\begin{array}{l}\mathrm{T} \text { (eg, whether sites reveal } \\
\text { their geographic location } \\
\text { or specific address of } \\
\text { consulting physicans) }\end{array}$ & $1 ?$ & No & 38 & 0 & Negative \\
\hline $\begin{array}{l}\text { Bogen- } \\
\text { Schutz, }{ }^{18} \\
2000\end{array}$ & $\begin{array}{l}\text { NR (October } \\
\text { 1998?) }\end{array}$ & $\begin{array}{l}3 \text { Sites providing } \\
\text { information on } \\
\text { psychoactive } \\
\text { drugs }\end{array}$ & $\begin{array}{l}\text { AC (a posteriori, based on } \\
\text { comparison with literature) }\end{array}$ & 1 & No & 25 & 25 & Positive \\
\hline $\begin{array}{l}\text { Boyer et al, }{ }^{19} \\
2001\end{array}$ & May 24, 2001 & $\begin{array}{l}7 \text { Partisan Web } \\
\text { sites } \\
\text { promulgating } \\
\text { information } \\
\text { about illicit } \\
\text { drugs }\end{array}$ & $\begin{array}{l}\text { A (a posteriori evaluation } \\
\text { against personal opinion of } \\
\text { experts whether sites } \\
\text { make potentially harmful } \\
\text { recommendations for the } \\
\text { management of the } \\
\text { adverse effects of illicit } \\
\text { drugs) }\end{array}$ & $>1$ & Yes & 12 & 57 & Negative \\
\hline $\begin{array}{l}\text { Breul et al, }{ }^{20} \\
1999\end{array}$ & 1998 & $\begin{array}{l}68 \text { Sites of French } \\
\text { health care } \\
\text { facilities }\end{array}$ & $\mathrm{T}$ (20 a priori items) & $1 ?$ & No & 31 & 0 & Neutral \\
\hline $\begin{array}{l}\text { Butzke and } \\
\text { Kramer, } \\
2000\end{array}$ & $\begin{array}{l}\text { August 3, } 1998 \\
\text {-May 15, } \\
1999\end{array}$ & $\begin{array}{l}136 \text { Sites of } \\
\text { university } \\
\text { departments of } \\
\text { orthopedics, } \\
\text { traumatology, } \\
\text { and } \\
\text { rheumatology } \\
\text { from G7 } \\
\text { countries } \\
\end{array}$ & $\begin{array}{l}\text { T (18 a priori items) } \\
\text { D (part of "qualitative criteria," } \\
\text { but no results reported) }\end{array}$ & $1 ?$ & No & 62 & 0 & Negative \\
\hline $\begin{array}{l}\text { Bykowski et } \\
\text { al, },^{22} 2000\end{array}$ & August 1997 & $\begin{array}{l}40 \text { Sites containing } \\
\text { information } \\
\text { about } \\
\text { cutaneous } \\
\text { laser surgery } \\
\end{array}$ & $\begin{array}{l}\text { C (8 a priori items) } \\
\text { T (disclaimer, references) }\end{array}$ & $1 ?$ & No & 62 & 14 & Negative \\
\hline $\begin{array}{c}\text { Chen et al, }{ }^{23} \\
2000\end{array}$ & $\begin{array}{l}\text { NR (published } \\
\text { August 2000) }\end{array}$ & $\begin{array}{l}141 \text { Sites } \\
\text { providing } \\
\text { information on } \\
4 \text { pediatric } \\
\text { surgery topics } \\
\end{array}$ & $\begin{array}{l}\text { A (a posteriori, based on } \\
\text { personal judgement of } 2 \\
\text { surgeons, score system) } \\
\text { C (a posteriori, based on } \\
\text { personal judgement of } 2 \\
\text { surgeons, score system) } \\
\text { T (2 a priori items: } \\
\text { "accountability criteria," } \\
\text { references) }\end{array}$ & 2 & No & 38 & 20 & Negative \\
\hline $\begin{array}{l}\text { Corpron and } \\
\text { Lelli, }{ }^{24} \\
2001\end{array}$ & $\begin{array}{l}\text { NR (presented Oct } \\
28,2000)\end{array}$ & $\begin{array}{l}8 \text { Sites about } \\
\text { intersex } \\
\text { anomalies }\end{array}$ & $\begin{array}{l}\text { A (a posteriori, based on } 2 \\
\text { textbooks) } \\
\mathrm{T} \text { (references to source of } \\
\text { information) }\end{array}$ & $1 ?$ & No & 31 & 14 & Negative \\
\hline
\end{tabular}

(continued) 
Online Table A. Included Studies Assessing Quality of Health Information on Web Sites or Web Pages* (cont)

\begin{tabular}{|c|c|c|c|c|c|c|c|c|}
\hline Study, Year & $\begin{array}{l}\text { Period } \\
\text { Conducted }\end{array}$ & $\begin{array}{l}\text { Study Domain, } \\
\text { Population }\end{array}$ & $\begin{array}{c}\text { Evaluation Method and } \\
\text { Criteria }\end{array}$ & $\begin{array}{l}\text { No. of } \\
\text { Raters }\end{array}$ & $\begin{array}{c}\text { Interrater } \\
\text { Reliability } \\
\text { Determined? }\end{array}$ & S-score & E-score & $\begin{array}{l}\text { Authors' } \\
\text { Conclusion }\end{array}$ \\
\hline $\begin{array}{l}\text { D'Alessandro } \\
\text { et al, }{ }^{25} \\
2001\end{array}$ & March 2000 & $\begin{array}{l}100 \text { (Final sample: } \\
\text { 89) documents } \\
\text { from pediatric } \\
\text { patient } \\
\text { education sites }\end{array}$ & $\begin{array}{l}\text { R (Flesch Reading Ease score } \\
\text { and Flesch-Kincaid } \\
\text { reading level with MS } \\
\text { Word 98; Fry formula and } \\
\text { SMOG handcalculated) }\end{array}$ & $1-2$ & Partially & 50 & 50 & Negative \\
\hline $\begin{array}{l}\text { Davison, }{ }^{26} \\
1996 \\
\text { Davison, } \\
1997\end{array}$ & February 1996 & $\begin{array}{l}167 \text { "Sites" (pages?) } \\
\text { containing } \\
\text { information } \\
\text { about nutrition, } \\
\text { food, and diet }\end{array}$ & $\begin{array}{l}\text { A (11 a priori items, from } \\
\text { guideline) }\end{array}$ & 2 & Yes & 56 & 86 & Negative \\
\hline $\begin{array}{l}\text { Diering and } \\
\text { Palmer, } \\
2001\end{array}$ & June-July 1999 & $\begin{array}{l}15 \text { Sites on urinary } \\
\text { incontinence } \\
\text { from } \\
\text { professional } \\
\text { organizations } \\
\text { targeted for } \\
\text { health care } \\
\text { providers }\end{array}$ & $\begin{array}{l}\text { T (10 a priori items, including } \\
\text { author/organization } \\
\text { credentials, currency, } \\
\text { references) } \\
\text { A (a posteriori, evaluated by } 2 \\
\text { reviewers, unclear whether } \\
\text { determined by consensus) } \\
\text { R (Flesch-Kincaid Grade Level) }\end{array}$ & 2 & No & 56 & 29 & Neutral \\
\hline $\begin{array}{l}\text { Doupi and van } \\
\text { der Lei, }{ }^{29} \\
1999\end{array}$ & $\begin{array}{l}\text { February-June } \\
1998\end{array}$ & $\begin{array}{l}14 \text { Sites offering } \\
\text { comprehensive } \\
\text { information on } \\
\text { prescription } \\
\text { medication; on } \\
\text { each of these } \\
\text { sites, } 6 \text { drug } \\
\text { information } \\
\text { articles } \\
\text { evaluated }\end{array}$ & $\begin{array}{l}\text { C (36 a priori items, based on } \\
\text { guidelines) } \\
\mathrm{T} \text { (15 items, eg, disclosure of } \\
\text { authorship, objectivity, } \\
\text { disclosure, and currency) }\end{array}$ & $1 ?$ & No & 12 & 43 & Negative \\
\hline $\begin{array}{l}\text { Dracos and } \\
\text { Seta, } \\
1998\end{array}$ & Summer 1997 & $\begin{array}{l}30 \text { Italian Web sites } \\
\text { with health } \\
\text { information for } \\
\text { patients }\end{array}$ & $\begin{array}{l}\text { T (4 Silberg criteria: authorship } \\
\text { disclosed, references, } \\
\text { sponsorhip disclosed, } \\
\text { dates) } \\
\text { R (subjective rating of } \\
\text { readability on a scale "very } \\
\text { good," "good," "not } \\
\text { sufficient") }\end{array}$ & $1 ?$ & No & 50 & 0 & Negative \\
\hline $\begin{array}{c}\text { Eachus, }^{31} \\
1999\end{array}$ & $\begin{array}{l}\text { NR (published } \\
\text { 1999) }\end{array}$ & $\begin{array}{l}86 \text { Coronary heart } \\
\text { disease sites }\end{array}$ & $\begin{array}{l}\text { S (1-8 points depending on } \\
\text { the "likely quality of the } \\
\text { site") }\end{array}$ & $1 ?$ & No & 50 & 0 & Positive \\
\hline $\begin{array}{l}\text { Ellamushi et } \\
\text { al, },^{32} 2001\end{array}$ & $\begin{array}{l}\text { NR (published July } \\
\text { 2001) }\end{array}$ & $\begin{array}{l}150 \text { Sites about } 5 \\
\text { different } \\
\text { neurosurgery } \\
\text { conditions and } \\
\text { procedures }\end{array}$ & $\begin{array}{l}\text { A ("usefulness: structured } \\
\text { treatment of a disease or } \\
\text { procedure aimed towards } \\
\text { patients and their families, } \\
\text { accurate") }\end{array}$ & $1 ?$ & No & 25 & 0 & Positive \\
\hline $\begin{array}{l}\text { Estrada et al, }{ }^{33} \\
\quad 2000\end{array}$ & $\begin{array}{l}\text { NR (submitted } \\
\quad \text { May 25, 2000) }\end{array}$ & $\begin{array}{l}9 \text { Patient } \\
\text { information } \\
\text { documents } \\
\text { about atrial } \\
\text { fibrillation and } \\
\text { warfarin from } 6 \\
\text { different sites }\end{array}$ & $\begin{array}{l}\text { R (SMOG, Flesch-Kincaid } \\
\text { Grade Level) }\end{array}$ & $\mathrm{N} / \mathrm{A}$ & Partially & 0 & 50 & Negative \\
\hline $\begin{array}{l}\text { Eysenbach, }{ }^{34} \\
1999\end{array}$ & March 1999 & $\begin{array}{c}10 \text { cyberpharmacies } \\
\text { selling sildanefil }\end{array}$ & $\begin{array}{l}\text { C (5 a posteriori items, } \\
\text { checking contraindications } \\
\text { on the prescribing form } \\
\text { asked) } \\
\text { R (consumer terms used) }\end{array}$ & $1 ?$ & No & 62 & 0 & Negative \\
\hline
\end{tabular}


Online Table A. Included Studies Assessing Quality of Health Information on Web Sites or Web Pages* (cont)

\begin{tabular}{|c|c|c|c|c|c|c|c|c|}
\hline Study, Year & $\begin{array}{c}\text { Period } \\
\text { Conducted }\end{array}$ & $\begin{array}{l}\text { Study Domain, } \\
\text { Population }\end{array}$ & $\begin{array}{c}\text { Evaluation Method and } \\
\text { Criteria }\end{array}$ & $\begin{array}{l}\text { No. of } \\
\text { Raters }\end{array}$ & $\begin{array}{c}\text { Interrater } \\
\text { Reliability } \\
\text { Determined? }\end{array}$ & S-score & E-score & $\begin{array}{l}\text { Authors' } \\
\text { Conclusion }\end{array}$ \\
\hline $\begin{array}{l}\text { Fitzmaurice } \\
\text { and } \\
\text { Adams, }{ }^{35} \\
2000\end{array}$ & $\begin{array}{l}\text { NR (submitted July } \\
\text { 1999) }\end{array}$ & $\begin{array}{l}42 \text { Sites and } 19 \\
\text { printed patient } \\
\text { information } \\
\text { leaflets on } \\
\text { hypertension }\end{array}$ & $\begin{array}{l}\text { AC (“marks were allocated for } \\
\text { content," } 8 \text { a priori criteria, } \\
\text { from consensus; listed for } \\
\text { non-Internet leaflets } \\
\text { only-unclear whether } \\
\text { Web pages were } \\
\text { evaluated using the same } \\
\text { criteria) } \\
\text { T (date provided, table of } \\
\text { contents) } \\
\text { R (Gunning Fog Index, } \\
\text { subjective marks for } \\
\text { writing style) } \\
\text { D (section headings present, } \\
\text { at least 12-point font) }\end{array}$ & $\begin{array}{l}2 \text { (or } 3 \text {, if } \\
\text { disagree- } \\
\text { ment } \\
>10 \% \text { in } \\
\text { score) }\end{array}$ & No & 25 & 60 & Neutral \\
\hline $\begin{array}{l}\text { Frasca et al, }{ }^{36} \\
\quad 2000\end{array}$ & $\begin{array}{l}\text { June 20, } 1999 \\
\text {-September } \\
15,1999\end{array}$ & 48 Anatomy sites & $\begin{array}{l}\text { CTD (same method as in } \\
\text { Voiglio et al90: raters } \\
\text { graded sites on a 0-5 } \\
\text { scale in the categories } \\
\text { navigability, illustration, } \\
\text { presentation, and text; the } \\
\text { latter being defined as } \\
\text { "value and amount of text" } \\
\text { without further criteria, } \\
\text { giving a maximum total } \\
\text { score of 20) }\end{array}$ & $1 ?$ & No & 50 & 0 & Neutral \\
\hline $\begin{array}{l}\text { Galimberti and } \\
\text { Jain, }{ }^{37} \\
2000\end{array}$ & $\begin{array}{l}\text { May 20-June 1, } \\
1999\end{array}$ & $\begin{array}{l}26 \text { Sites about } \\
\text { hysterectomy }\end{array}$ & $\begin{array}{l}\text { AC (5 broad a priori items } \\
\text { from information leaflet } \\
\text { produced by Royal } \\
\text { College of Obstetricians } \\
\text { and Gynaecologists) } \\
\text { T ( } 7 \text { technical criteria based on } \\
\text { HON principles) } \\
\text { R (subjective rating whether "it } \\
\text { was felt to be clearly } \\
\text { presented in a legible way } \\
\text { and in plain English") }\end{array}$ & $1 ?$ & No & 50 & 40 & Neutral \\
\hline Gillies, $^{38} 2000$ & $\begin{array}{l}\text { NR (published July } \\
\text { 2000) }\end{array}$ & $\begin{array}{l}292 \text { Pages from } \\
126 \text { unique } \\
\text { sites providing } \\
\text { information on } \\
\text { cancer }\end{array}$ & $\begin{array}{l}\text { A (NR) } \\
\text { C (NR) } \\
\text { T (authority, scope, } \\
\text { completeness, disclosure, } \\
\text { accuracy, validity, } \\
\text { objectivity, uniqueness, } \\
\text { currency, audience, } \\
\text { accessibility, navigation, } \\
\text { functionality, links, } \\
\text { interactivity) } \\
\text { D ("aesthetic features") }\end{array}$ & 1 & No & 25 & 10 & Neutral \\
\hline $\begin{array}{l}\text { Gillois et al, }{ }^{39} \\
1999\end{array}$ & $\begin{array}{l}\text { NR (published } \\
\text { 1999) }\end{array}$ & $\begin{array}{l}8 \text { Sites providing } \\
\text { cardiovascular } \\
\text { risk prediction } \\
\text { tools }\end{array}$ & $\begin{array}{l}\text { A (a posteriori, "information } \\
\text { was based on some } \\
\text { explicit evidence") } \\
\text { T (42 a priori items) } \\
\text { D (Visual Analog Scale) }\end{array}$ & $3-4$ & Yes & 38 & 57 & Negative \\
\hline $\begin{array}{l}\text { Gordon et al, }{ }^{40} \\
2001\end{array}$ & $\begin{array}{l}\text { November 21, } \\
1999\end{array}$ & $\begin{array}{l}41 \text { Sites providing } \\
\text { information } \\
\text { about breast } \\
\text { augmentation }\end{array}$ & $\begin{array}{l}\text { AC (3 surgeons evaluated } \\
\text { accuracy of descriptions } \\
\text { of procedural details and } \\
\text { whether they are "limited } \\
\text { in quantity," as well as } \\
\text { description of } \\
\text { complications, against } \\
\text { personal opinion) } \\
\text { T (provision of interactivity) }\end{array}$ & 3 & No & 50 & 15 & Negative \\
\hline $\begin{array}{l}\text { Graber et al, }{ }^{41} \\
\quad 1999\end{array}$ & $\begin{array}{l}\text { NR (submitted } \\
\text { November } \\
\text { 1998) }\end{array}$ & $\begin{array}{l}50 \text { Sites relevant } \\
\text { for patient } \\
\text { education (32 } \\
\text { topics) } \\
\end{array}$ & $\begin{array}{l}\text { R (Flesch reading score, } \\
\text { Flesch-Kinkaid reading } \\
\text { level) }\end{array}$ & N/A & $\mathrm{N} / \mathrm{A}$ & 25 & $\mathrm{~N} / \mathrm{A}$ & Negative \\
\hline $\begin{array}{l}\text { Griffiths and } \\
\text { Christen- } \\
\text { son, }{ }^{42} \\
2000\end{array}$ & March 1999 & $\begin{array}{l}21 \text { Sites providing } \\
\text { information } \\
\text { about } \\
\text { depression }\end{array}$ & $\begin{array}{l}\text { AC (43 a priori items from } \\
\text { guideline, including } 5 \text { core } \\
\text { items, plus } 17 \text { further } \\
\text { "issues," also a global } \\
\text { score on a } 10 \text {-point scale) } \\
\text { T (9 a priori criteria according } \\
\text { to Silberg et } \mathrm{al}^{7} \text { ) }\end{array}$ & 2 & Yes & 50 & 90 & Negative \\
\hline
\end{tabular}


Online Table A. Included Studies Assessing Quality of Health Information on Web Sites or Web Pages* (cont)

\begin{tabular}{|c|c|c|c|c|c|c|c|c|}
\hline Study, Year & $\begin{array}{c}\text { Period } \\
\text { Conducted }\end{array}$ & $\begin{array}{c}\text { Study Domain, } \\
\text { Population }\end{array}$ & $\begin{array}{c}\text { Evaluation Method and } \\
\text { Criteria }\end{array}$ & $\begin{array}{l}\text { No. of } \\
\text { Raters }\end{array}$ & $\begin{array}{c}\text { Interrater } \\
\text { Reliability } \\
\text { Determined? }\end{array}$ & S-score & E-score & $\begin{array}{l}\text { Authors' } \\
\text { Conclusion }\end{array}$ \\
\hline $\begin{array}{l}\text { Groot et al, } \\
2001\end{array}$ & $\begin{array}{l}\text { NR (accepted } \\
\text { February } 8, \\
\text { 2001) }\end{array}$ & $\begin{array}{l}36 \text { Sites with } \\
\text { information } \\
\text { about } \\
\text { diagnosis and } \\
\text { treatment of } \\
\text { ankle sprain }\end{array}$ & $\begin{array}{l}\text { A (10 a priori items, based on } \\
\text { guideline and systematic } \\
\text { reviews, each item scored } \\
\text { 0-2 points) } \\
\text { T/“Credibility score” (9 items: } \\
\text { source disclosed, context, } \\
\text { currency, utility, editorial } \\
\text { review process, hierarchy } \\
\text { of evidence, statement of } \\
\text { original source, disclaimer, } \\
\text { omissions noted) [no } \\
\text { details provided on how } \\
\text { currency or utility, for } \\
\text { example, were evaluated] }\end{array}$ & 1 & No & 50 & 57 & Negative \\
\hline $\begin{array}{l}\text { Harmon et al, }{ }^{44} \\
2000\end{array}$ & $\begin{array}{l}\text { NR (published July } \\
\text { 2000) }\end{array}$ & $\begin{array}{l}120 \text { Anesthesia } \\
\text { sites }\end{array}$ & $\begin{array}{l}\text { AC (34 a priori items in } 5 \\
\text { categories, each scored } \\
\text { as complete, inadequate, } \\
\text { not mentioned, or } \\
\text { incorrect) }\end{array}$ & $1 ?$ & No & 50 & 20 & Negative \\
\hline $\begin{array}{l}\text { Hatfield et al, }{ }^{45} \\
1999\end{array}$ & $\begin{array}{l}\text { October } 1997 \\
\text {-November } \\
1997\end{array}$ & $\begin{array}{l}4 \text { Sites offering } \\
\text { comprehensive } \\
\text { information on } \\
\text { prescription } \\
\text { medication, on } \\
\text { each of these } \\
\text { sites } 30 \text { drug } \\
\text { information } \\
\text { articles } \\
\text { evaluated } \\
\end{array}$ & $\begin{array}{l}\text { A (3 a priori items, from } \\
\text { textbooks) } \\
\text { C (22 a priori items) } \\
\text { T (site sponsorship, authors } \\
\text { and contributors, } \\
\text { references, dates of most } \\
\text { recent updates, ease of } \\
\text { use) }\end{array}$ & $1-3 ?$ & No & 38 & 40 & Neutral \\
\hline $\begin{array}{l}\text { Hellawell et } \\
\text { al, }{ }^{46} 2000\end{array}$ & $\begin{array}{l}\text { NR (accepted } \\
\quad \text { June 12, 2000) }\end{array}$ & $\begin{array}{l}50 \text { Sites providing } \\
\text { information } \\
\text { about prostate } \\
\text { cancer and } 50 \\
\text { sites about } \\
\text { testicular } \\
\text { cancer }\end{array}$ & $\begin{array}{l}\text { A (a posteriori, rated } \\
\text { "unconventional" or } \\
\text { "conventional" compared } \\
\text { with textbooks and } \\
\text { literature) } \\
\text { C (Soot-score, } 5 \text { broad } \\
\text { weighted items rated on a } \\
\text { scale 0-10) } \\
\text { T (references) }\end{array}$ & 2 & No & 25 & 40 & Positive \\
\hline $\begin{array}{l}\text { Hernández- } \\
\text { Borges et } \\
\text { al, }{ }^{47} 1999\end{array}$ & $\begin{array}{l}\text { March-April 15, } \\
1998\end{array}$ & $\begin{array}{c}363 \text { Sites related } \\
\text { to pediatrics }\end{array}$ & $\begin{array}{l}\mathrm{T} \text { (time since last update, } \\
\text { counter present, author } \\
\text { provided) } \\
\mathrm{S} \text { (impact factor of Web site } \\
\text { author) }\end{array}$ & $1 ?$ & No & 50 & 0 & Negative \\
\hline $\begin{array}{l}\text { Hersh et al, }{ }^{48} \\
1998\end{array}$ & $\begin{array}{l}\text { NR (published } \\
\text { October 1998) }\end{array}$ & $\begin{array}{l}639 \text { Pages } \\
\text { retrieved in an } \\
\text { attempt to } \\
\text { answer } 50 \\
\text { clinical } \\
\text { questions }\end{array}$ & $\begin{array}{l}\text { T (9 items, eg, disclosure of } \\
\text { authorship, credentials, } \\
\text { affiliation, funding, date } \\
\text { posted, attribution) }\end{array}$ & 1 & No & 19 & 25 & Negative \\
\hline $\begin{array}{l}\text { Hoffman- } \\
\text { Goetz and } \\
\text { Clarke, } \\
2000\end{array}$ & $\begin{array}{r}\text { November } 1998 \\
\text {-June } 1999\end{array}$ & $\begin{array}{l}136 \text { Sites } \\
\text { providing } \\
\text { information } \\
\text { about breast } \\
\text { cancer }\end{array}$ & $\begin{array}{l}\mathrm{T} \text { (Silberg criteria, privacy } \\
\text { disclaimer) }\end{array}$ & 2 & Partially & 50 & 50 & Negative \\
\hline $\begin{array}{l}\text { Impicciatore } \\
\text { et al, }{ }^{00,51} \\
1997\end{array}$ & December 1996 & $\begin{array}{l}41 \text { Pages } \\
\text { containing } \\
\text { information } \\
\text { about home } \\
\text { management } \\
\text { of children with } \\
\text { fever }\end{array}$ & $\begin{array}{l}\text { AC (5 a priori items, from } \\
\text { guideline/textbook) }\end{array}$ & $1 ?$ & No & 75 & 60 & Negative \\
\hline Jiang, ${ }^{52} 2000$ & March 20, 1998 & $\begin{array}{l}70 \text { Sites providing } \\
\text { information } \\
\text { about } \\
\text { orthodontics }\end{array}$ & $\begin{array}{l}\text { A (a posteriori, personal } \\
\text { opinion on whether } \\
\text { information correct, } \\
\text { questionable or incorrect) } \\
\text { T (Silberg criteria: authorship, } \\
\text { attribution, currency, } \\
\text { disclosure) }\end{array}$ & $1 ?$ & No & 62 & 0 & Neutral \\
\hline
\end{tabular}

(continued) 
Online Table A. Included Studies Assessing Quality of Health Information on Web Sites or Web Pages* (cont)

\begin{tabular}{|c|c|c|c|c|c|c|c|c|}
\hline Study, Year & $\begin{array}{c}\text { Period } \\
\text { Conducted }\end{array}$ & $\begin{array}{c}\text { Study Domain, } \\
\text { Population }\end{array}$ & $\begin{array}{c}\text { Evaluation Method and } \\
\text { Criteria }\end{array}$ & $\begin{array}{l}\text { No. of } \\
\text { Raters }\end{array}$ & $\begin{array}{c}\text { Interrater } \\
\text { Reliability } \\
\text { Determined? }\end{array}$ & S-score & E-score & $\begin{array}{l}\text { Authors' } \\
\text { Conclusion }\end{array}$ \\
\hline $\begin{array}{l}\text { Kihlstrom, } \\
\quad 2001\end{array}$ & "Late 1999" & $\begin{array}{l}71 \text { US pharmacy } \\
\text { benefit } \\
\text { management } \\
\text { sites }\end{array}$ & $\begin{array}{l}\text { T (18 technical criteria, } \\
\text { including "information } \\
\text { gathering with cookies," } \\
\text { feedback mechanisms, } \\
\text { "visitor-friendly print-size," } \\
\text { currency disclosure, } \\
\text { copyright notice, site map, } \\
\text { search function, plug-in } \\
\text { required, more than } 2 \\
\text { levels beyond home page, } \\
\text { site purpose evident, } \\
\text { credentials of author, } \\
\text { disclaimer for medical } \\
\text { advice, confidentiality } \\
\text { statement, advertising } \\
\text { policy, separation of } \\
\text { advertising from content, } \\
\text { HON logo present) }\end{array}$ & $1 ?$ & No & 36 & 0 & Neutral \\
\hline $\begin{array}{l}\text { Latthe et al, }{ }^{54} \\
\quad 2000\end{array}$ & $\begin{array}{l}\text { December 22, } \\
1998\end{array}$ & $\begin{array}{l}9 \text { Pages providing } \\
\text { patient } \\
\text { information on } \\
\text { menorrhagia }\end{array}$ & $\begin{array}{l}\text { AC (9 a priori items relating to } \\
\text { the treatment, from } \\
\text { guidelines) } \\
\mathrm{T} \text { (disclosure of author/source, } \\
\text { date, editorial review } \\
\text { process, indication of the } \\
\text { strength of the evidence) }\end{array}$ & 2 & Yes & 88 & 90 & Negative \\
\hline $\begin{array}{l}\text { Latthe et al, }{ }^{55} \\
\quad 2000\end{array}$ & March 19, 1999 & $\begin{array}{l}32 \text { Sites (pages?) } \\
\text { providing } \\
\text { patient } \\
\text { information on } \\
\text { emergency } \\
\text { contraception }\end{array}$ & $\begin{array}{l}\text { AC }(12,5 \text {, and } 5 \text { a priori items } \\
\text { relating to the } 3 \text { different } \\
\text { methods of emergency } \\
\text { contraception, from } \\
\text { guidelines) } \\
\mathrm{T} \text { (disclosure of author/source, } \\
\text { date, editorial review } \\
\text { process, indication of the } \\
\text { strength of the evidence) }\end{array}$ & 2 & Yes & 75 & 90 & Negative \\
\hline $\begin{array}{l}\text { Latthe et al, }{ }^{56} \\
\quad 2000\end{array}$ & June 24, 1999 & $\begin{array}{l}12 \text { Sites on female } \\
\text { sterilization }\end{array}$ & $\begin{array}{l}\text { AC (10 a priori items from } \\
\text { "evidence-based clinical } \\
\text { guidelines" of the Royal } \\
\text { College of Obstetricians } \\
\text { and Gynaecologists) } \\
\mathrm{T} \text { (disclosure of author/source, } \\
\text { date, review process ["seal } \\
\text { of approval"], indication of } \\
\text { the strength of the } \\
\text { evidence) }\end{array}$ & 2 & Yes & 88 & 90 & Negative \\
\hline Li et al, ${ }^{57} 2001$ & $\begin{array}{l}\text { September } \\
\text { 1996/January } \\
\text { 1998/February } \\
1999\end{array}$ & $\begin{array}{l}\text { Time series of } \\
74 / 63 / 54 \text { sites } \\
\text { providing } \\
\text { information on } \\
\text { back pain }\end{array}$ & $\begin{array}{l}\text { A ("evidence-based," a } \\
\text { posteriori against } \\
\text { guidelines, literature, } \\
\text { personal opinion) } \\
\text { AC (overall rating } \\
\text { "poor/fair/good" } \\
\text { concerning accuracy and } \\
\text { comprehensiveness) } \\
\text { T (references) }\end{array}$ & $2 / 1 / 2$ & Yes & 50 & 65 & Negative \\
\hline $\begin{array}{l}\text { Libertiny et al, }{ }^{58} \\
2000\end{array}$ & $\begin{array}{l}\text { September 10-21, } \\
1999\end{array}$ & $\begin{array}{l}41 \text { Sites providing } \\
\text { information on } \\
\text { varicose vein } \\
\text { surgery }\end{array}$ & $\begin{array}{l}\text { "Soot score": } \\
\text { C (6 broad items with different } \\
\text { weights, leading to an } \\
\text { "information score" with } \\
100 \text { maximum points) } \\
\text { T (date, authors, references } \\
\text { provided) }\end{array}$ & 2 & Yes & 62 & 57 & Negative \\
\hline $\begin{array}{l}\text { Lissman and } \\
\text { Boehn- } \\
\text { line, }{ }^{59} 2001\end{array}$ & April 2000 & $\begin{array}{l}176 \text { Sites } \\
\text { (including } \\
\text { duplicates?) } \\
\text { about } \\
\text { depression } \\
\text { treatment }\end{array}$ & $\begin{array}{l}\text { AC (3 broad a priori items for } \\
\text { therapy [sites had to } \\
\text { mention consultation, } \\
\text { medication, } \\
\text { psychotherapy, without } \\
\text { specifying which } \\
\text { medications], and } 14 \text { a } \\
\text { priori diagnostic criteria } \\
\text { from DSM-N leading to a } \\
\text { score of } 0-14 \text { points with } 1 \\
\text { point deducted for each } \\
\text { erroneous statement) }\end{array}$ & 1? & No & 50 & 55 & Negative \\
\hline
\end{tabular}


Online Table A. Included Studies Assessing Quality of Health Information on Web Sites or Web Pages* (cont)

\begin{tabular}{|c|c|c|c|c|c|c|c|c|}
\hline Study, Year & $\begin{array}{l}\text { Period } \\
\text { Conducted }\end{array}$ & $\begin{array}{l}\text { Study Domain, } \\
\text { Population }\end{array}$ & $\begin{array}{c}\text { Evaluation Method and } \\
\text { Criteria }\end{array}$ & $\begin{array}{l}\text { No. of } \\
\text { Raters }\end{array}$ & $\begin{array}{c}\text { Interrater } \\
\text { Reliability } \\
\text { Determined? }\end{array}$ & S-score & E-score & $\begin{array}{l}\text { Authors' } \\
\text { Conclusion }\end{array}$ \\
\hline Mallory, ${ }^{60} 1997$ & November 1996 & $\begin{array}{c}69 \text { Sites related to } \\
\text { HIV and AIDS }\end{array}$ & $\begin{array}{l}\text { AC (a posteriori, rated on a } \\
\text { 4-point scale from "poor" } \\
\text { to "excellent," no explicit } \\
\text { criteria) }\end{array}$ & 1 & No & 50 & 10 & Neutral \\
\hline $\begin{array}{l}\text { Martinez- } \\
\text { Lopez and } \\
\text { Ruiz- } \\
\text { Crespo, } \\
1998 \\
191\end{array}$ & April 1, 1997 & $\begin{array}{l}57 \text { sites about } \\
\text { rotator cuff } \\
\text { rupture }\end{array}$ & $\begin{array}{l}\text { A (2 a posteriori items } \\
\text { assessing whether "the } \\
\text { presented theory or } \\
\text { technique is usually } \\
\text { considered appropiate" } \\
\text { and whether treatment } \\
\text { limitations are discussed, } \\
\text { against personal opinion) } \\
\text { T (6 items, including authority } \\
\text { of authors, updates, } \\
\text { references, loading time) } \\
\text { R (subjective assessment, } \\
\text { whether style is easily } \\
\text { readable) } \\
\text { D (legibility: appropriate } \\
\text { background, layout) }\end{array}$ & $1 ?$ & No & 62 & 0 & Neutral \\
\hline $\begin{array}{l}\text { Maugans et } \\
\text { al, }^{62} 1998\end{array}$ & $\begin{array}{l}\text { NR (paper } \\
\quad \text { received } \\
\quad \text { February 1998) }\end{array}$ & $\begin{array}{l}\text { Unclear number of } \\
\text { sites } \\
\text { containing } \\
\text { information } \\
\text { about } 10 \\
\text { different } \\
\text { pediatric } \\
\text { neurosurgery } \\
\text { topics }\end{array}$ & $\begin{array}{l}\text { A (a posteriori, compared } \\
\text { against personal opinion) }\end{array}$ & $1 ?$ & No & 25 & 14 & Positive \\
\hline $\begin{array}{l}\text { McClung et } \\
\quad \mathrm{al}^{6,}{ }^{63} 1998\end{array}$ & $\begin{array}{l}\text { NR (paper } \\
\text { submitted } \\
\text { June 1997) }\end{array}$ & $\begin{array}{l}70 \text { Pages } \\
\text { containing } \\
\text { information on } \\
\text { treatment of } \\
\text { acute diarrhea } \\
\text { in childhood } \\
\text { (60 traditional } \\
\quad+10 \\
\text { alternative) }\end{array}$ & $\begin{array}{l}\text { A (unspecified number of a } \\
\text { priori items, from guideline) }\end{array}$ & $1 ?$ & No & 50 & 43 & Negative \\
\hline $\begin{array}{l}\text { Miles et al, }{ }^{64} \\
2000\end{array}$ & $\begin{array}{l}\text { NR (published May } \\
\text { 2000) }\end{array}$ & $\begin{array}{l}45 \text { Sites providing } \\
\text { information on } \\
\text { weight-loss } \\
\text { diets }\end{array}$ & $\begin{array}{l}\text { A (a posteriori, based on } \\
\text { guidelines) }\end{array}$ & $1 ?$ & No & 38 & 36 & Negative \\
\hline $\begin{array}{l}\text { Murphy et al, }{ }^{65} \\
2001\end{array}$ & $\begin{array}{l}\text { NR (published April } \\
\text { 2001) }\end{array}$ & $\begin{array}{l}43 \text { Neurology } \\
\text { patient } \\
\text { education } \\
\text { brochures, } \\
\text { among them } 8 \\
\text { from the } \\
\text { WWW (2 } \\
\text { different Web } \\
\text { sites) }\end{array}$ & $\begin{array}{l}\text { R (Fog Index) } \\
\mathrm{D} \text { (part of SAM) } \\
\text { Suitability Assessment of } \\
\quad \text { Materials (SAM) score }\end{array}$ & 1 & No & 0 & 25 & Negative \\
\hline $\begin{array}{l}\text { Oermann and } \\
\text { Wilson, } 66 \\
2000\end{array}$ & $\begin{array}{l}\text { NR (published July } \\
\text { 2000) }\end{array}$ & $\begin{array}{l}10 \text { Sites containing } \\
\text { quality-of-care } \\
\text { information }\end{array}$ & $\begin{array}{l}\text { R (Flesch-Kincaid of } 10 \\
\text { documents, three } \\
\text { 100-word paragraphs } \\
\text { from each) }\end{array}$ & $\mathrm{N} / \mathrm{A}$ & $\mathrm{N} / \mathrm{A}$ & 0 & N/A & Neutral \\
\hline $\begin{array}{l}\text { O'Mahony, }{ }^{67} \\
1999\end{array}$ & $\begin{array}{l}\text { October- } \\
\text { December } \\
1998\end{array}$ & $\begin{array}{l}60 \text { Sites from } \\
\text { Ireland hosted } \\
\text { by health care } \\
\text { providers, } \\
\text { educational or } \\
\text { professional } \\
\text { bodies }\end{array}$ & $\begin{array}{l}\text { T (Silberg criteria: disclosure of } \\
\text { authorship, affiliation and } \\
\text { credentials, references } \\
\text { and sources, disclosure of } \\
\text { site ownership, } \\
\text { sponsorship, etc; date } \\
\text { posted, email posted) } \\
\text { R (Flesch-Kincaid reading } \\
\text { level) [done only for the } 47 \\
\text { service information } \\
\text { provides] }\end{array}$ & $1 ?$ & No & 31 & 0 & Negative \\
\hline
\end{tabular}


Online Table A. Included Studies Assessing Quality of Health Information on Web Sites or Web Pages* (cont)

\begin{tabular}{|c|c|c|c|c|c|c|c|c|}
\hline Study, Year & $\begin{array}{c}\text { Period } \\
\text { Conducted }\end{array}$ & $\begin{array}{l}\text { Study Domain, } \\
\text { Population }\end{array}$ & $\begin{array}{c}\text { Evaluation Method and } \\
\text { Criteria }\end{array}$ & $\begin{array}{l}\text { No. of } \\
\text { Raters }\end{array}$ & $\begin{array}{c}\text { Interrater } \\
\text { Reliability } \\
\text { Determined? }\end{array}$ & S-score & E-score & $\begin{array}{l}\text { Authors' } \\
\text { Conclusion }\end{array}$ \\
\hline $\begin{array}{l}\text { Ogushi and } \\
\text { Tatsumi, }{ }^{68} \\
2000 \\
\text { Tatsumi et al, }{ }^{69} \\
2001\end{array}$ & $\begin{array}{l}\text { November } 21 \\
\text {-December 5, } \\
1999\end{array}$ & $\begin{array}{l}1147 \text { Sites of } \\
\text { Japanese } \\
\text { medical } \\
\text { institutions } \\
\text { (hospitals and } \\
\text { clinics), } 516 \text { of } \\
\text { which } \\
\text { contained } \\
\text { medical } \\
\text { information } \\
\text { that was } \\
\text { evaluated for } \\
\text { accuracy and } \\
\text { design }\end{array}$ & $\begin{array}{l}\text { A (a posteriori evaluation } \\
\text { against personal opinion of } \\
\text { specialists, rated as "no } \\
\text { problem in the content," } \\
\text { "minor problem," or } \\
\text { "serious problem") } \\
\text { T (statement of information } \\
\text { providers' name, address, } \\
\text { telephone, fax, privacy } \\
\text { policy, unencrypted } \\
\text { transmission for personal } \\
\text { information, third-party } \\
\text { seal) } \\
\text { D (3-point scale } \\
\text { ["good"-"difficult to see") }\end{array}$ & 1 or more & No & 29 & 15 & Negative \\
\hline $\begin{array}{l}\text { Pandolfini et } \\
\quad \mathrm{al}^{70} 2000\end{array}$ & $\begin{array}{l}\text { June } 1997 \\
\text {-January } 1998\end{array}$ & $\begin{array}{l}19 \text { Pages } \\
\text { containing } \\
\text { information } \\
\text { about cough in } \\
\text { children }\end{array}$ & $\begin{array}{l}\text { A (6 a priori items, from } \\
\text { guidelines) } \\
\text { C (4 a priori items, from } \\
\text { MEDLINE search) } \\
\text { T (6-item checklist: lists } \\
\text { authors, authors } \\
\text { credentials, lists } \\
\text { references, relevant links, } \\
\text { statement of "not } \\
\text { substitute for professional } \\
\text { care," currency) }\end{array}$ & $1 ?$ & No & 62 & 50 & Negative \\
\hline $\begin{array}{l}\text { Payne and } \\
\text { Miller, }^{71} \\
2000\end{array}$ & $\begin{array}{l}\text { NR (published } \\
\text { 2000) }\end{array}$ & $\begin{array}{l}75 \text { Sites about } \\
\text { podiatrics (flat } \\
\text { feet, corns, } \\
\text { heel spurs, } \\
\text { bunions) }\end{array}$ & $\begin{array}{l}\text { T (aggregate rating score 1-6 } \\
\text { incorporating author and } \\
\text { qualification disclosure, } \\
\text { references, date provided, } \\
\text { links available, information } \\
\text { not biased) }\end{array}$ & $1 ?$ & No & 38 & 0 & Negative \\
\hline $\begin{array}{l}\text { Peroutka, }{ }^{72} \\
2001\end{array}$ & January 2000 & $\begin{array}{l}51 \text { Headache } \\
\text { pages }\end{array}$ & $\begin{array}{l}\text { Aggregate score (maximum, } \\
\text { 100), containing } \\
\text { A (a posteriori, no clear } \\
\text { criteria, maximum } 20 \\
\text { points), } \\
\text { C (a posteriori, } 20 \text { points } \\
\text { maximum for "clinical } \\
\text { content," "positively } \\
\text { associated with amount of } \\
\text { information") } \\
\text { T (20 points maximum for } \\
\text { references, } 20 \text { points } \\
\text { maximum for author, date } \\
\text { of creation or last edit, } \\
\text { sponsor, disclaimer) } \\
\text { D (maximum } 20 \text { points, } \\
\text { incorporating ease of use, } \\
\text { presence of an overview } \\
\text { etc) }\end{array}$ & $1 ?$ & No & 71 & 0 & Negative \\
\hline $\begin{array}{l}\text { Roberts and } \\
\text { Spooner, } \\
1997\end{array}$ & December 1996 & $\begin{array}{l}300 \text { Sites and } \\
\text { mailing lists } \\
\text { related to } \\
\text { podiatry }\end{array}$ & $\begin{array}{l}\text { S (Web sites rated for } \\
\text { "reliability of the author" on } \\
\text { a 5-point scale) }\end{array}$ & 1 & No & 33 & 25 & Neutral \\
\hline $\begin{array}{l}\text { Sacchetti et } \\
\text { all, }^{74} 1999\end{array}$ & $\begin{array}{l}\text { January 1, } 1998 \\
\text {-August 31, } \\
98\end{array}$ & $\begin{array}{l}\text { 61 Sites containing } \\
\text { patient } \\
\text { education on } \\
\text { sildanefil }\end{array}$ & $\begin{array}{l}\text { Self-developed composite } \\
\text { score system, } \\
\text { incorporating accuracy, } \\
\text { comprehensiveness, and } \\
\text { objectivity, each scored } \\
\text { from 1-4. } \\
\text { A (a posteriori, compared } \\
\text { against literature/rater } \\
\text { consensus, 4-point scale } \\
\text { "statement incorrect," } \\
\text { "some incorrect," } \\
\text { "correct," "correct, } \\
\text { referenced") } \\
\text { C (4-point scale: "discusses } \\
\text { isolated/several/most/all } \\
\text { issues," no explicit items } \\
\text { specified, a posteriori) }\end{array}$ & 2 & No & 62 & 30 & Negative \\
\hline
\end{tabular}


Online Table A. Included Studies Assessing Quality of Health Information on Web Sites or Web Pages* (cont)

\begin{tabular}{|c|c|c|c|c|c|c|c|c|}
\hline Study, Year & $\begin{array}{l}\text { Period } \\
\text { Conducted }\end{array}$ & $\begin{array}{l}\text { Study Domain, } \\
\text { Population }\end{array}$ & $\begin{array}{l}\text { Evaluation Method and } \\
\text { Criteria }\end{array}$ & $\begin{array}{l}\text { No. of } \\
\text { Raters }\end{array}$ & $\begin{array}{c}\text { Interrater } \\
\text { Reliability } \\
\text { Determined? }\end{array}$ & S-score & E-score & $\begin{array}{c}\text { Authors' } \\
\text { Conclusion }\end{array}$ \\
\hline $\begin{array}{c}\text { Sandvik, } \\
1999\end{array}$ & Spring 1998 & $\begin{array}{l}75 \text { Sites, } \\
\text { cyberdoctors } \\
\text { and } \\
\text { newsgroups } \\
\text { providing } \\
\text { advice on } \\
\text { female urinary } \\
\text { incontinence }\end{array}$ & $\begin{array}{l}\text { Self-developed composite } \\
\text { score system, } \\
\text { incorporating technical } \\
\text { criteria and completeness: } \\
\text { T (ownership, navigability, } \\
\text { interactivity, balance, } \\
\text { currency, source, } \\
\text { authorship) } \\
\text { AC (14 a priori broad topic } \\
\text { items, each rated whether } \\
\text { they are comprehensively } \\
\text { explained, briefly } \\
\text { explained, mentioned, or } \\
\text { not mentioned. Unclear } \\
\text { whether the } \\
\text { comprehensiveness scale } \\
\text { implies accuracy. Criterion } \\
\text { standard unclear) }\end{array}$ & 1 & No & 12 & 30 & Positive \\
\hline $\begin{array}{l}\text { Shon and } \\
\text { Musen, }{ }^{76} \\
1999\end{array}$ & $\begin{array}{l}\text { NR (published } \\
\text { 1999) }\end{array}$ & $\begin{array}{l}97 \text { Sites containing } \\
\text { information on } \\
\text { breast cancer } \\
\text { treatment }\end{array}$ & $\begin{array}{l}\text { A (a posteriori, based on } \\
\text { personal opinion) } \\
\text { T (authorship, attribution, } \\
\text { currency, and disclosure) }\end{array}$ & $1 ?$ & No & 44 & 0 & Positive \\
\hline $\begin{array}{c}\text { Sing et al, }{ }^{77} \\
2001\end{array}$ & July 1999 & 73 Sites of airlines & $\begin{array}{l}\text { T (e-mail addresses present, } \\
\text { feedback tested) }\end{array}$ & $1 ?$ & No & 33 & 0 & Negative \\
\hline $\begin{array}{l}\text { Smith et al, }{ }^{78} \\
2000\end{array}$ & November 1997 & $\begin{array}{c}41 \text { Sites providing } \\
\text { information on } \\
\text { sex education }\end{array}$ & C (10 items) & 3 or 1 & No & 62 & 36 & Neutral \\
\hline $\begin{array}{c}\text { Soot et al, }{ }^{79} \\
1999\end{array}$ & $\begin{array}{l}\text { NR (submitted } \\
\text { September 15, } \\
\text { 1998) }\end{array}$ & $\begin{array}{l}146 \text { Sites } \\
\text { containing } \\
\text { information on } \\
\text { vascular } \\
\text { surgery (aortic } \\
\text { aneurysm, } \\
\text { carotid } \\
\text { surgery, leg } \\
\text { ischemia) }\end{array}$ & $\begin{array}{l}\text { A (therapy classified as } \\
\text { "conventional, } \\
\text { unconventional, or } \\
\text { misleading," a posteriori, } \\
\text { compared against } \\
\text { personal opinion and FDA } \\
\text { approval) } \\
\text { C (6 broad topic items, no } \\
\text { specific content } \\
\text { requirements. Each item } \\
\text { scored with up to } 10 \\
\text { points and weighted with } \\
\text { a item-specific factor from } \\
1 \text { to } 3, \text { leading to an } \\
\text { "information score" with } \\
\text { maximum } 100 \text { points) } \\
\text { T (references given) }\end{array}$ & C: $2 \mathrm{~A}: 1$ & Yes & 38 & 40 & Negative \\
\hline $\begin{array}{l}\text { Stausberg and } \\
\text { Fuchs, }^{80} \\
2000\end{array}$ & September 1999 & $\begin{array}{l}184 \text { Presentations } \\
\text { of German } \\
\text { surgical } \\
\text { departments }\end{array}$ & $\begin{array}{l}\text { T (11 items, including "last } \\
\text { update," "navigation," and } \\
9 \text { further items deemed to } \\
\text { be important on home } \\
\text { pages of surgical } \\
\text { departments, eg, calendar } \\
\text { of events, research } \\
\text { publications, job offers) } \\
\text { C (a posteriori, } \\
\text { comprehensiveness of } \\
\text { medical information rated } \\
\text { "very good: diseases and } \\
\text { therapeutic interventions } \\
\text { explained in } \\
\text { detail"-"sufficient: } \\
\text { described } \\
\text { shortly"-"insufficient") } \\
\text { D (layout, on scale very good, } \\
\text { sufficient, insufficient) }\end{array}$ & $1-2$ & Yes & 29 & 36 & Negative \\
\hline
\end{tabular}


Online Table A. Included Studies Assessing Quality of Health Information on Web Sites or Web Pages* (cont)

\begin{tabular}{|c|c|c|c|c|c|c|c|c|}
\hline Study, Year & $\begin{array}{c}\text { Period } \\
\text { Conducted }\end{array}$ & $\begin{array}{l}\text { Study Domain, } \\
\text { Population }\end{array}$ & $\begin{array}{c}\text { Evaluation Method and } \\
\text { Criteria }\end{array}$ & $\begin{array}{l}\text { No. of } \\
\text { Raters }\end{array}$ & $\begin{array}{c}\text { Interrater } \\
\text { Reliability } \\
\text { Determined? }\end{array}$ & S-score & E-score & $\begin{array}{l}\text { Authors' } \\
\text { Conclusion }\end{array}$ \\
\hline $\begin{array}{r}\text { Stausberg et } \\
\quad \text { al, }{ }^{81} 2001\end{array}$ & $\begin{array}{l}\text { Unclear (either } \\
\text { March 29, } \\
\text { 2000, or May } \\
\text { 29, } 2000\end{array}$ & $\begin{array}{l}171 \text { Presentations } \\
\text { of German } \\
\text { surgical } \\
\text { departments }\end{array}$ & $\begin{array}{l}\text { T (11 items, including "last } \\
\text { update," "navigation," and } \\
9 \text { further items deemed to } \\
\text { be important on home } \\
\text { pages of surgical } \\
\text { departments, eg, calendar } \\
\text { of events, research } \\
\text { publications, job offers) } \\
\text { C (a posteriori, } \\
\text { comprehensiveness of } \\
\text { medical information rated } \\
\text { "very good: diseases and } \\
\text { therapeutic interventions } \\
\text { explained in } \\
\text { detail"-"sufficient: } \\
\text { described } \\
\text { shortly"-"insufficient") } \\
\text { D (layout, on scale very good, } \\
\text { sufficient, insufficient) }\end{array}$ & 6 & Yes & 29 & 43 & Negative \\
\hline $\begin{array}{l}\text { Stone and } \\
\text { Jumper, } \\
2001\end{array}$ & December 1998 & $\begin{array}{l}80 \text { Sites providing } \\
\text { information on } \\
\text { age-related } \\
\text { macular } \\
\text { degeneration }\end{array}$ & $\begin{array}{l}\text { A (a posteriori, against } \\
\text { literature, classified as } \\
\text { "conventional, } \\
\text { experimental, alternative") }\end{array}$ & $1 ?$ & No & 50 & 14 & Negative \\
\hline $\begin{array}{l}\text { Suarez- } \\
\text { Almazor et } \\
\text { al, }{ }^{83} 2001\end{array}$ & May 1998 & $\begin{array}{l}286 \text { Web pages } \\
\text { on } 205 \text { sites } \\
\text { about } \\
\text { rheumatoid } \\
\text { arthritis }\end{array}$ & $\begin{array}{l}\text { A (a posteriori, against } \\
\text { personal opinion } \\
\text { "alternative = not taught } \\
\text { widely at US medical } \\
\text { schools or generally } \\
\text { available at US hospitals") }\end{array}$ & $1-2$ & No & 50 & 21 & Negative \\
\hline $\begin{array}{l}\text { Tamm et al, }{ }^{84} \\
2000\end{array}$ & 16 March 1998 & $\begin{array}{l}38 \text { Sites providing } \\
\text { advice on } \\
\text { screening } \\
\text { mammography }\end{array}$ & $\begin{array}{l}\text { A (1 a priori item, from } \\
\text { guideline) } \\
\text { T (Silberg criteria: disclosure of } \\
\text { authorship, ownership, } \\
\text { date of publication, or } \\
\text { update provided, } \\
\text { attribution) }\end{array}$ & 3 & No & 62 & 71 & Negative \\
\hline $\begin{array}{l}\text { Thompson and } \\
\text { Howard, }{ }^{85} \\
2000\end{array}$ & March 2000 & $\begin{array}{l}21 \text { HMO Web sites } \\
\text { (of the 25 } \\
\text { largest HMOs) }\end{array}$ & $\begin{array}{l}\text { C (5 a priori items, "shown in } \\
\text { the literature to be most } \\
\text { important to consumers") }\end{array}$ & $1 ?$ & No & 29 & 29 & Neutral \\
\hline $\begin{array}{l}\text { Tu and } \\
\text { Zimmer- } \\
\text { man,86 } \\
2001\end{array}$ & $\begin{array}{l}\text { NR (covers } \\
\text { information } \\
\text { published in } \\
\text { 1998) }\end{array}$ & $\begin{array}{l}97 \text { Sites providing } \\
\text { information on } \\
\text { eating } \\
\text { disorders, } \\
\text { anorexia, } \\
\text { bulimia } \\
\end{array}$ & $\begin{array}{l}\mathrm{T} \text { (8 items, mainly disclaimers } \\
\text { and caveats) }\end{array}$ & $1-3$ & Partially & 38 & 50 & Negative \\
\hline $\begin{array}{l}\text { Türp et al, }, 87 \\
2001 \\
\text { Neugebauer } \\
\text { and Türp, } \\
2001 \\
2001 \\
\end{array}$ & $\begin{array}{l}\text { May 30-June 9, } \\
2000\end{array}$ & $\begin{array}{l}47 \text { Web pages on } \\
\text { myoarthropa- } \\
\text { thies of the } \\
\text { mastication } \\
\text { system }\end{array}$ & $\begin{array}{l}\text { A (a posteriori, 5-point score } \\
\text { system) } \\
\text { T (DISCERN) (partly C: } 1 \text { item } \\
\text { of DISCERN refers to } \\
\text { balance) }\end{array}$ & $1 ?$ & No & 50 & 14 & Negative \\
\hline $\begin{array}{l}\text { Veronin and } \\
\text { Ramirez, } \\
2000 \\
\quad\end{array}$ & $\begin{array}{c}\text { December } 1998 \\
\text {-May } 1999\end{array}$ & $\begin{array}{l}184 \text { Sites (98 } \\
\text { claims) about } \\
\text { the herbal } \\
\text { remedy } \\
\text { Opuntia }\end{array}$ & $\begin{array}{l}\text { A (a posteriori comparison } \\
\text { against primary literature, } \\
\text { including extensive } \\
\text { database searches and } \\
\text { quality assessment of } 51 \\
\text { scientific reports) } \\
\text { T (references listed, disclaimer } \\
\text { present) }\end{array}$ & $1 ?$ & No & 62 & 14 & Negative \\
\hline $\begin{array}{l}\text { Voiglio et al, }{ }^{90} \\
1999\end{array}$ & $\begin{array}{l}\text { February } 2 \\
\text {-June 10, } \\
1998\end{array}$ & 52 Anatomy sites & $\begin{array}{l}\text { ACTD (raters graded sites on } \\
\text { a 0-5 scale in the } \\
\text { categories navigability, } \\
\text { illustration, presentation, } \\
\text { and text; the latter being } \\
\text { defined as "value and } \\
\text { amount of text" without } \\
\text { further criteria, giving a } \\
\text { total score of maximum } \\
\text { 20) }\end{array}$ & $1(-4 ?)$ & No & 62 & 0 & Neutral \\
\hline $\begin{array}{l}\text { von Danwitz et } \\
\text { al, }{ }^{91} 1999\end{array}$ & October 1999 & $\begin{array}{l}39 \text { Sites about } \\
\text { diabetes } \\
\text { (German) }\end{array}$ & $\begin{array}{l}\text { T (13 a priori "objective" and } \\
12 \text { a priori "subjective" } \\
\text { items) } \\
\text { D (visual design, as part of } \\
\text { subjective evaluation) }\end{array}$ & 5 & Yes & 50 & 75 & Negative \\
\hline
\end{tabular}

(continued) 
Online Table A. Included Studies Assessing Quality of Health Information on Web Sites or Web Pages* (cont)

\begin{tabular}{|c|c|c|c|c|c|c|c|c|}
\hline Study, Year & $\begin{array}{c}\text { Period } \\
\text { Conducted }\end{array}$ & $\begin{array}{l}\text { Study Domain, } \\
\text { Population }\end{array}$ & $\begin{array}{c}\text { Evaluation Method and } \\
\text { Criteria }\end{array}$ & $\begin{array}{l}\text { No. of } \\
\text { Raters }\end{array}$ & $\begin{array}{c}\text { Interrater } \\
\text { Reliability } \\
\text { Determined? }\end{array}$ & S-score & E-score & $\begin{array}{l}\text { Authors' } \\
\text { Conclusion } \\
\end{array}$ \\
\hline $\begin{array}{l}\text { Willems and } \\
\text { Bouvy, }{ }^{92,93} \\
2001\end{array}$ & $\begin{array}{l}\text { January-February } \\
2001\end{array}$ & $\begin{array}{l}23 \text { Dutch health } \\
\text { portals, } \\
\text { including } 6 \\
\text { cyberpharma- } \\
\text { cies }\end{array}$ & $\begin{array}{l}\text { AC (a priori? accuracy and } \\
\text { completeness were } \\
\text { evaluated by } 3 \text { raters: } \\
\text { "with a standard } \\
\text { questionnaire the quality of } \\
8 \text { medical topics were } \\
\text { tested against Dutch } \\
\text { standards"-no further } \\
\text { information given) } \\
\text { T (technical criteria, including } \\
\text { source of information } \\
\text { clear, target audience } \\
\text { clear, search functionality, } \\
\text { all rated on 5-point scale } \\
\text { ["very good"-"good"- } \\
\text { "satisfactory"-"moderate"- } \\
\text { "bad") } \\
\text { R (subjective rating on "use of } \\
\text { language") } \\
\text { D ("clarity of design") }\end{array}$ & $\begin{array}{l}\text { T:2 } \\
\text { A:3 } \\
\text { R,D:9-66 }\end{array}$ & No & 12 & 80 & Negative \\
\hline $\begin{array}{l}\text { Wilson et al, }{ }^{94} \\
\quad 2000\end{array}$ & $\begin{array}{l}\text { October 1997-July } \\
\quad 1998\end{array}$ & $\begin{array}{l}49 \text { Documents } \\
\text { from NCl's } \\
\text { CancerNet } \\
\text { Web site }\end{array}$ & $\begin{array}{l}\text { R (Flesch-Kincaid reading } \\
\text { level, measured with } \\
\text { WinWord } 95 \text { v7.0); cultural } \\
\text { sensitivity (5 yes/no } \\
\text { questions) }\end{array}$ & 2 & Yes & 20 & 75 & Negative \\
\hline $\begin{array}{l}\text { Wright et al, }{ }^{95} \\
1999\end{array}$ & June 1997 & $\begin{array}{l}13 \text { Sites containing } \\
\text { treatment } \\
\text { information on } \\
\text { chronic fatigue } \\
\text { syndrome } \\
\text { (CFS) in } \\
\text { children }\end{array}$ & $\begin{array}{l}\text { AC (accuracy rated a } \\
\text { posteriori, compared } \\
\text { against literature; } \\
\text { completeness rating } \\
\text { against } 7 \text { broad a priori } \\
\text { criteria) }\end{array}$ & $1 ?$ & No & 50 & 20 & Negative \\
\hline
\end{tabular}


Online Table B. Overview of Quality Criteria Used by Studies and Their Evaluation Results*

\begin{tabular}{|c|c|c|c|c|c|}
\hline Study, Year & Description & $\begin{array}{l}\text { Not } \\
\text { Complying }\end{array}$ & Total & $\begin{array}{c}\text { Not } \\
\text { Complying, \% }\end{array}$ & MA† \\
\hline $\begin{array}{l}\text { Content of Site: Accuracy } \\
\quad \text { Abbott, }{ }^{11} 2000\end{array}$ & $\begin{array}{l}\text { Sites on MMR vaccine containing inaccurate or unbalanced } \\
\text { information }\end{array}$ & 24 & 40 & 60.0 & \\
\hline Beredjiklian et $\mathrm{al},{ }^{13} 2000$ & $\begin{array}{l}\text { Sites on carpal tunnel syndrome classified as misleading (14\%) } \\
\text { or unconventional (9\%) }\end{array}$ & 41 & 175 & 23.0 & \\
\hline \multirow[t]{8}{*}{ Berland et al, ${ }^{15} 2001$} & $\begin{array}{l}\text { English-language breast cancer sites rated not "completely } \\
\text { correct" (average for several clinical elements) }\end{array}$ & $\mathrm{N} / \mathrm{A}$ & 10 & 9 & \\
\hline & $\begin{array}{l}\text { English-language childhood asthma sites rated not } \\
\text { "completely correct" (average for several clinical elements) }\end{array}$ & $\mathrm{N} / \mathrm{A}$ & 9 & 16 & \\
\hline & $\begin{array}{l}\text { English-language depression sites rated not "completely } \\
\text { correct" (average for several clinical elements) }\end{array}$ & $N / A$ & 10 & 25 & \\
\hline & $\begin{array}{l}\text { English-language obesity sites rated not "completely correct" } \\
\text { (average for several clinical elements) }\end{array}$ & $N / A$ & 10 & 14 & \\
\hline & $\begin{array}{l}\text { Spanish-language breast cancer sites rated not "completely } \\
\text { correct" (average for several clinical elements) }\end{array}$ & $N / A$ & 4 & 4 & \\
\hline & $\begin{array}{l}\text { Spanish-language childhood asthma sites rated not } \\
\text { "completely correct" (average for several clinical elements) }\end{array}$ & $\mathrm{N} / \mathrm{A}$ & 4 & 47 & \\
\hline & $\begin{array}{l}\text { Spanish-language depression sites rated not "completely } \\
\text { correct" (average for several clinical elements) }\end{array}$ & $\mathrm{N} / \mathrm{A}$ & 4 & 37 & \\
\hline & $\begin{array}{l}\text { Spanish-language obesity sites rated not "completely correct" } \\
\text { (average for several clinical elements) }\end{array}$ & $N / A$ & 4 & 32 & \\
\hline Biermann et al, ${ }^{16} 1999$ & $\begin{array}{l}\text { Web pages with clearly erroneous information about Ewing } \\
\text { sarcoma }\end{array}$ & 4 & $65 \ddagger$ & 6.2 & \\
\hline Bogenschutz, ${ }^{18} 2000$ & $\begin{array}{l}\text { Inaccurate information on } 3 \text { drug sites concerning biological } \\
\text { sources of psychoactive chemicals }\end{array}$ & 0 & 13 & 0.0 & \\
\hline Boyer et al, ${ }^{19} 2001$ & $\begin{array}{l}\text { Partisan sites about illicit drugs making potentially harmful } \\
\text { recommendations for the management of the adverse } \\
\text { effects of illicit drugs }\end{array}$ & 7 & 7 & 100 & \\
\hline Chen et al, ${ }^{23} 2000$ & $\begin{array}{l}\text { Pediatric surgery sites judged inaccurate ( } 2 \text { surgeons giving } \\
\text { each } 0-2 \text { points for accuracy, composite score < }<\text { ) }\end{array}$ & 29 & 119 & 24 & \\
\hline Corpron and Lelli, ${ }^{24} 2001$ & $\begin{array}{l}\text { Sites about ambiguous genitalia offering misleading } \\
\text { information or information not conforming to standard } \\
\text { recommendations }\end{array}$ & 3 & 8 & 37.5 & \\
\hline $\begin{array}{l}\text { Davison, }{ }^{26} 1996 \\
\text { Davison, }{ }^{27} 1997 \\
\end{array}$ & Noncompliance with Canadian nutritional guideline & 76 & 167 & 45.5 & \\
\hline Diering and Palmer, ${ }^{28} 2001$ & $\begin{array}{l}\text { Sites on urinary incontinence from professional organizations } \\
\text { where "accuracy could not be determined" }\end{array}$ & 3 & 15 & 20 & \\
\hline $\begin{array}{l}\text { Galimberti and Jain, }^{37} \\
2000\end{array}$ & $\begin{array}{l}\text { Grossly incorrect or misleading statements made on sites } \\
\text { about hysterectomy }\end{array}$ & 3 & 26 & 11.5 & \\
\hline Gillois et al, ${ }^{39} 1999$ & $\begin{array}{l}\text { Cardiovascular risk prediction sites with "no valid use of } \\
\text { information" }\end{array}$ & 4 & 8 & 50.0 & \\
\hline \multirow[t]{3}{*}{ Gordon et al, ${ }^{40} 2001$} & $\begin{array}{l}\text { Procedural details provided on breast augmentation sites } \\
\text { inaccurate }\end{array}$ & 3 & 28 & 11 & \\
\hline & $\begin{array}{l}\text { Complications provided on breast augmentation sites } \\
\text { inaccurate }\end{array}$ & 2 & 19 & 11 & \\
\hline & $\begin{array}{l}\text { Chat transcripts from } 3 \text { sites providing information on breast } \\
\text { augmentation judged inaccurate }\end{array}$ & 0 & 14 & 0 & \\
\hline $\begin{array}{l}\text { Griffiths and Christensen, }{ }^{42} \\
2000\end{array}$ & $\begin{array}{l}\text { Sites about depression contradicting or providing material } \\
\text { inconsistent with } 5 \text { core items from guideline }\end{array}$ & 12 & 21 & 58 & \\
\hline Hatfield et al, ${ }^{45} 1999$ & $\begin{array}{l}\text { Drug information sites with not } 100 \% \text { accurate drug } \\
\text { information }\end{array}$ & 1 & 4 & 25.0 & \\
\hline \multirow[t]{2}{*}{ Hellawell et al, ${ }^{46} 2000$} & $\begin{array}{l}\text { Sites about prostate cancer providing "unconventional" } \\
\text { information }\end{array}$ & 2 & 50 & 4 & \\
\hline & $\begin{array}{l}\text { Sites about testicular cancer providing "unconventional" } \\
\text { information }\end{array}$ & 3 & 50 & 6 & \\
\hline Jiang, ${ }^{52} 2000$ & Sites about orthodontics rated incorrect & 0 & 70 & 0 & \\
\hline \multirow[t]{2}{*}{ Li et $a l,{ }^{57} 2001$} & $\begin{array}{l}\text { Sites about back pain rated "not evidence-based" (September } \\
\text { 1996) }\end{array}$ & 45 & 73 & 61.6 & \\
\hline & $\begin{array}{l}\text { Sites about back pain rated "not evidence-based" (February } \\
\text { 1999) }\end{array}$ & 40 & 54 & 74.1 & \\
\hline
\end{tabular}


Online Table B. Overview of Quality Criteria Used by Studies and Their Evaluation Results* (cont)

\begin{tabular}{|c|c|c|c|c|c|}
\hline Study, Year & Description & $\begin{array}{c}\text { Not } \\
\text { complying }\end{array}$ & Total & $\begin{array}{c}\text { Not } \\
\text { Complying, \% }\end{array}$ & MA† \\
\hline $\begin{array}{l}\text { Content of Site: Accuracy (cont) } \\
\text { Martinez-Lopez and } \\
\text { Ruiz-Crespo, }{ }^{61} 1998\end{array}$ & $\begin{array}{l}\text { Theories or techniques on pages about rotator cuff rupture } \\
\text { rated inappropriate }\end{array}$ & 11 & 57 & 19.3 & \\
\hline McClung et al, ${ }^{63} 1998$ & $\begin{array}{l}\text { Noncompliance with AAP guidelines about childhood diarrhea } \\
\text { (A) }\end{array}$ & 48 & 70 & 68.6 & \\
\hline Miles et al, ${ }^{64} 2000$ & Sites about weight loss and diet giving unsound advice & 40 & 45 & 88.9 & \\
\hline Ogushi and Tatsumi, 682000 & $\begin{array}{l}\text { "Serious problem" on Japanese Web sites (additional } 40 \\
{[7.8 \%] \text { had a minor problem) }}\end{array}$ & 5 & 516 & 1 & \\
\hline Pandolfini et al, ${ }^{70} 2000$ & $\begin{array}{l}\text { Sites about cough in children giving more incorrect advice } \\
\text { than correct advice }\end{array}$ & 10 & 19 & 52.6 & \\
\hline Shon and Musen, ${ }^{76} 1999$ & Pages about breast cancer judged misleading & 5 & 97 & 5.1 & \\
\hline Soot et al, ${ }^{79} 1999$ & $\begin{array}{l}\text { Sites about vascular surgery classified as misleading (28\%) or } \\
\text { unconventional (4\%) }\end{array}$ & 16 & 50 & 32.0 & \\
\hline Stone and Jumper, ${ }^{82} 2001$ & $\begin{array}{l}\text { Sites about age-related macular degeneration providing } \\
\text { "unconventional" information (14\% alternative, } 7 \% \\
\text { experimental) }\end{array}$ & 17 & 80 & 21 & \\
\hline Suarez-Almazor et al, ${ }^{83} 2001$ & $\begin{array}{l}\text { Alternative therapy information ("not taught widely at US } \\
\text { medical schools or generally available at US hospitals") on } \\
\text { Web pages about rheumatoid arthritis }\end{array}$ & 131 & 286 & 45.8 & \\
\hline Tamm et al, ${ }^{84} 2000$ & Sites not reflecting US guidelines on mammography frequency & 5 & 38 & 13.0 & \\
\hline Türp et al, ${ }^{87} 2001$ & $\begin{array}{l}\text { Pages about temporomandibular disorders where medical } \\
\text { quality was rated "weak" (score MWQ }<3 \text { ) }\end{array}$ & 40 & 47 & 85.1 & \\
\hline \multirow[t]{2}{*}{ Veronin and Ramirez, ${ }^{89} 2000$} & $\begin{array}{l}\text { Claims about Opuntia found to have conflicting or } \\
\text { contradictory reports about effects in the literature }\end{array}$ & 3 & 33 & 9.1 & \\
\hline & $\begin{array}{l}\text { Claims about Opuntia not supported by any reports in the } \\
\text { literature }\end{array}$ & 65 & 98 & 66.3 & \\
\hline Willems and Bouvy, ${ }^{93} 2001$ & Accuracy on Dutch sites rated "bad" on 5-point scale & 1 & 23 & 4.3 & \\
\hline \multirow[t]{3}{*}{ Wright et al, ${ }^{95} 1999$} & $\begin{array}{l}\text { Sites on CFS in children giving unsupported etiologic } \\
\text { explanations }\end{array}$ & 4 & 13 & 30.8 & \\
\hline & $\begin{array}{l}\text { Sites on CFS in children erroneously suggesting large amount } \\
\text { of rest }\end{array}$ & 11 & 13 & 15.4 & \\
\hline & $\begin{array}{l}\text { Not reflecting treatment advice of a study about CFS in } \\
\text { children }\end{array}$ & 11 & 13 & 84.6 & \\
\hline $\begin{array}{l}\text { Content of Site: Completeness } \\
\text { Chen et al, }{ }^{23} 2000\end{array}$ & $\begin{array}{l}\text { Pediatric surgery sites judged incomplete ( } 2 \text { surgeons giving } \\
\text { each } 0-2 \text { points for completeness, composite score }<3 \text { ) }\end{array}$ & 122 & 131 & 93 & \\
\hline Latthe et al, ${ }^{54} 2000$ & $\begin{array}{l}\text { Pages that did not mention all } 9 \text { information items deemed } \\
\text { essential for treatment of menorrhagia }\end{array}$ & 8 & 9 & 88.9 & \\
\hline Latthe et al, ${ }^{55} 2000$ & $\begin{array}{l}\text { Sites that did not mention all } 22 \text { information items deemed } \\
\text { essential for emergency contraception }\end{array}$ & 32 & 32 & 100.0 & \\
\hline Latthe et al, ${ }^{56} 2000$ & $\begin{array}{l}\text { Sites that did not mention all } 10 \text { information items deemed } \\
\text { essential for female sterilization }\end{array}$ & 11 & 12 & 91.6 & \\
\hline $\begin{array}{l}\text { Lissman and Boehnlein, } \\
2001\end{array}$ & $\begin{array}{l}\text { Site about depression not containing information on all } 3 \\
\text { treatment items regarded important by the investigator } \\
\text { (consulting, medications, psychotherapy) }\end{array}$ & 103 & $178 \S$ & 57.9 & \\
\hline Pandolfini et al, ${ }^{70} 2000$ & $\begin{array}{l}\text { Sites which did not mention all } 4 \text { information items deemed } \\
\text { essential about childhood cough }\end{array}$ & 16 & 19 & 84.2 & \\
\hline Smith et al, ${ }^{78} 2000$ & $\begin{array}{l}\text { Sites about sex education not mentioning all } 10 \text { educational } \\
\text { items }\end{array}$ & 38 & 41 & 92.7 & \\
\hline Willems and Bouvy, ${ }^{93} 2001$ & $\begin{array}{l}\text { Completeness on Dutch sites rated "bad" (lowest rating on } \\
5 \text {-point scale) }\end{array}$ & 2 & 23 & 8.7 & \\
\hline $\begin{array}{l}\text { Content of Site: Standard of Care } \\
\text { Armstrong et al, }{ }^{12} 1999\end{array}$ & $\begin{array}{l}\text { Sites selling sildanefil without offering or requiring an online } \\
\text { medical evaluation }\end{array}$ & 31 & 77 & 40 & \\
\hline Bloom and lannacone, ${ }^{17} 1999$ & $\begin{array}{l}\text { Sites selling prescription drugs to consumers without requiring } \\
\text { a prescription or online medical evaluation }\end{array}$ & 9 & 46 & 19.6 & \\
\hline
\end{tabular}




\begin{tabular}{|c|c|c|c|c|c|}
\hline Study, Year & Description & $\begin{array}{l}\text { Not } \\
\text { complying }\end{array}$ & Total & $\begin{array}{l}\text { Not } \\
\text { Complying, \% }\end{array}$ & MA† \\
\hline \multirow[t]{8}{*}{$\begin{array}{l}\text { Content of Site: Completeness } \\
\text { and Accuracy } \\
\text { Berland et al, }{ }^{15} 2001\end{array}$} & $\begin{array}{l}\text { English-language breast cancer sites with minimal or no } \\
\text { coverage or incorrect (average across elements) }\end{array}$ & $\mathrm{N} / \mathrm{A}$ & 10 & 47 & \\
\hline & $\begin{array}{l}\text { English-language childhood asthma sites with minimal or no } \\
\text { coverage or incorrect (range across elements) }\end{array}$ & $\mathrm{N} / \mathrm{A}$ & 9 & 64 & \\
\hline & $\begin{array}{l}\text { English-language depression sites with minimal or no } \\
\text { coverage or incorrect (range across elements) }\end{array}$ & $\mathrm{N} / \mathrm{A}$ & 10 & 56 & \\
\hline & $\begin{array}{l}\text { English language obesity sites with minimal or no coverage or } \\
\text { incorrect (range across elements) }\end{array}$ & $\mathrm{N} / \mathrm{A}$ & 10 & 63 & \\
\hline & $\begin{array}{l}\text { Spanish language breast cancer sites with minimal or no } \\
\text { coverage or incorrect (average across elements) }\end{array}$ & $\mathrm{N} / \mathrm{A}$ & 4 & 61 & \\
\hline & $\begin{array}{l}\text { Spanish language childhood asthma sites with minimal or no } \\
\text { coverage or incorrect (range across elements) }\end{array}$ & N/A & 4 & 77 & \\
\hline & $\begin{array}{l}\text { Spanish language depression sites with minimal or no } \\
\text { coverage or incorrect (range across elements) }\end{array}$ & $\mathrm{N} / \mathrm{A}$ & 4 & 88 & \\
\hline & $\begin{array}{l}\text { Spanish language obesity sites with minimal or no coverage or } \\
\text { incorrect (range across elements) }\end{array}$ & $\mathrm{N} / \mathrm{A}$ & 4 & 85 & \\
\hline $\begin{array}{l}\text { Galimberti and Jain, } \\
2000\end{array}$ & $\begin{array}{l}\text { Sites about hysterectomy not containing accurately all } 5 \text { items } \\
\text { considered important }\end{array}$ & 16 & 26 & 61.5 & \\
\hline Impicciatore et al, ${ }^{51} 1997$ & Noncompliance with guideline about childhood fever $(A+C)$ & 37 & 41 & 90.2 & \\
\hline \multirow[t]{2}{*}{ Li et al, ${ }^{57} 2001$} & $\begin{array}{l}\text { Sites about back pain rated "poor" ("very limited and/or } \\
\text { inaccurate information") overall (September 1996) }\end{array}$ & 15 & 73 & 20.5 & \\
\hline & $\begin{array}{l}\text { Sites about back pain rated "poor" ("very limited and/or } \\
\text { inaccurate information") overall (February 1999) }\end{array}$ & 20 & 54 & 37.0 & \\
\hline Voiglio et al, ${ }^{90} 1999$ & $\begin{array}{l}\text { Anatomy sites where text ("value and amount of text") was } \\
\text { rated } 0 \text { (on a scale 0-5) (unclear whether accuracy was } \\
\text { evaluated as well, no clear criteria for "value" and "amount" } \\
\text { given) }\end{array}$ & 5 & 52 & 9.6 & \\
\hline \multicolumn{6}{|l|}{ Design and Aesthetics } \\
\hline Stausberg and Fuchs, ${ }^{80} 2000$ & $\begin{array}{l}\text { "Extremely insufficient layout" on Web sites of German surgical } \\
\text { departments }\end{array}$ & 21 & 184 & 11.4 & \\
\hline Voiglio et al, ${ }^{90} 1999$ & $\begin{array}{l}\text { Anatomy sites where presentation ("visual aspect and legibility } \\
\text { of the sites") was rated } 0 \text { (on a scale 0-5) }\end{array}$ & 0 & 52 & 0 & \\
\hline Willems and Bouvy, ${ }^{93} 2001$ & Clarity of design: sites rated "bad" on 5-point scale & 0 & 23 & 0 & \\
\hline \multicolumn{6}{|l|}{$\begin{array}{l}\text { Design and Aesthetics: Images } \\
\text { and Illustrations }\end{array}$} \\
\hline Voiglio et al, ${ }^{90} 1999$ & $\begin{array}{l}\text { Anatomy sites where illustration ("quality of the different } \\
\text { pictures, diagrams and photographs contained in the site") } \\
\text { was rated } 0 \text { (on a scale 0-5) }\end{array}$ & 3 & 52 & 5.8 & \\
\hline $\begin{array}{l}\text { Disclosure: Authorship } \\
\text { Breul et al, }{ }^{20} 1999\end{array}$ & No identity of editor/author disclosed on French hospital sites & 41 & 68 & 60 & a \\
\hline Doupi and van der Lei, ${ }^{29} 1999$ & No name of an individual author & 11 & 14 & 78.6 & $\mathrm{a}$ \\
\hline Dracos and Seta, ${ }^{30} 1998$ & Author not provided on Italian sites & 2 & 30 & 6.7 & $\mathrm{a}$ \\
\hline $\begin{array}{l}\text { Griffiths and Christensen, }{ }^{42} \\
2000\end{array}$ & Authorship not disclosed on depression sites & 8 & 21 & 38.1 & a \\
\hline Hatfield et al, ${ }^{45} 1999$ & No authors given & 1 & 4 & 25.0 & a \\
\hline $\begin{array}{l}\text { Hernández-Borges et al, }{ }^{47} \\
1999\end{array}$ & No editor/author's name was given & 226 & 363 & 62.3 & a \\
\hline Hersh et al, ${ }^{48} 1998$ & No author indicated & 435 & 629 & 69.2 & a \\
\hline Jiang, ${ }^{52} 2000$ & Authorship not revealed on orthodontics sites & 12 & 70 & 17.1 & a \\
\hline Latthe et al, ${ }^{54} 2000$ & $\begin{array}{l}\text { No name of the author or institutions name given on pages on } \\
\text { menorrhagia }\end{array}$ & 2 & 9 & 22.2 & $\mathrm{a}$ \\
\hline Latthe et $a l,{ }^{55} 2000$ & $\begin{array}{l}\text { No clear mentioning of author on emergency contraception } \\
\text { sites }\end{array}$ & 4 & 32 & 12.5 & a \\
\hline Latthe et al, ${ }^{56} 2000$ & $\begin{array}{l}\text { No clear display of the author or institutions name given on } \\
\text { sites on female sterilization }\end{array}$ & 3 & 12 & 25 & a \\
\hline
\end{tabular}

(continued) 
Online Table B. Overview of Quality Criteria Used by Studies and Their Evaluation Results* (cont)

\begin{tabular}{|c|c|c|c|c|c|}
\hline Study, Year & Description & $\begin{array}{c}\text { Not } \\
\text { complying }\end{array}$ & Total & $\begin{array}{c}\text { Not } \\
\text { Complying, \% }\end{array}$ & MA† \\
\hline $\begin{array}{l}\text { Disclosure: Authorship (cont) } \\
\quad \text { Libertiny et al, }{ }^{58} 2000\end{array}$ & $\begin{array}{l}\text { Sites about varicose veins surgery where authors were } \\
\text { unidentifiable }\end{array}$ & 3 & 41 & 7.3 & a \\
\hline $\begin{array}{l}\text { Martinez-Lopez and } \\
\text { Ruiz-Crespo, }{ }^{61} 1998\end{array}$ & $\begin{array}{l}\text { Author can not be identified, including first and last name, on } \\
\text { pages about rotator cuff rupture }\end{array}$ & 11 & 57 & 19.3 & a \\
\hline O’Mahony, ${ }^{67} 1999$ & $\begin{array}{l}\text { No details of the authors of the content on Irish health } \\
\text { information providers }\end{array}$ & 12 & 18 & 66.7 & a \\
\hline Pandolfini et al, ${ }^{70} 2000$ & No authors listed & 5 & 19 & 26.3 & a \\
\hline Sandvik, ${ }^{75} 1999$ & Authors not given & 54 & 75 & 72 & a \\
\hline Shon and Musen, ${ }^{76} 1999$ & No author name on page & 78 & 97 & 80 & a \\
\hline Tamm et al, ${ }^{84} 2000$ & Authors not given & 28 & 38 & 73.7 & a \\
\hline von Danwitz et al, ${ }^{91} 1999$ & No identity of editor/author disclosed & 10 & 39 & 26 & a \\
\hline $\begin{array}{l}\text { Disclosure: Ownership } \\
\quad \text { Galimberti and Jain, }{ }^{37} 2000\end{array}$ & $\begin{array}{l}\text { Sites about hysterectomy not disclosing the "nature of the } \\
\text { organization behind it" }\end{array}$ & 1 & 26 & 3.8 & b \\
\hline $\begin{array}{l}\text { Griffiths and Christensen, }{ }^{42} \\
2000\end{array}$ & Ownership not disclosed on depression sites & 1 & 21 & 4.8 & b \\
\hline Groot et al, ${ }^{43} 2001$ & Source not disclosed & 0 & 36 & 0 & $\mathrm{~b}$ \\
\hline Sandvik, ${ }^{75} 1999$ & Ownership not disclosed & 0 & 75 & 0 & $\mathrm{~b}$ \\
\hline Tamm et al, ${ }^{84} 2000$ & Ownership not disclosed & 0 & 38 & 0 & $\mathrm{~b}$ \\
\hline $\begin{array}{l}\text { Disclosure: Location } \\
\quad \text { Bloom and lannacone, }{ }^{17} 1999\end{array}$ & $\begin{array}{l}\text { Sites selling prescription drugs to consumers without revealing } \\
\text { geographical location (city and country) }\end{array}$ & 41 & 46 & 89.1 & \\
\hline $\begin{array}{l}\text { Disclosure: Person Responsible } \\
\text { Ogushi and Tatsumi, }{ }^{68} 2000\end{array}$ & $\begin{array}{l}\text { Information providers name, including person who manages or } \\
\text { is responsible for the Web site, not stated clearly on } \\
\text { Japanese sites }\end{array}$ & 298 & 1147 & 26.1 & \\
\hline $\begin{array}{l}\text { Disclosure: Source } \\
\text { Groot et al, }{ }^{43} 2001\end{array}$ & Original source not disclosed & 11 & 36 & 30.6 & c \\
\hline Hatfield et al, ${ }^{45} 1999$ & No source of drug information given & 2 & 4 & 50.0 & c \\
\hline Türp et $a l,{ }^{87} 2001$ & $\begin{array}{l}\text { DISCERN item 4: Not clear what sources of information were } \\
\text { used to compile the publication (other than the author or } \\
\text { producer) (Web pages on myoarthropathies of the } \\
\text { mastication system) }\end{array}$ & 36 & 47 & 76.6 & c \\
\hline Willems and Bouvy, ${ }^{93} 2001$ & Origin of information clear: sites rated "bad" on 5-point scale & 0 & 23 & 0 & $\mathrm{c}$ \\
\hline \multirow[t]{2}{*}{$\begin{array}{l}\text { Disclosure: Sponsorship/ } \\
\text { Funding Source } \\
\text { Doupi and van der Lei, }{ }^{29} \\
1999\end{array}$} & No sponsorship disclosure on drug information sites & 8 & 14 & 57.1 & $d$ \\
\hline & No source of funding disclosed on drug information sites & 6 & 14 & 42.9 & d \\
\hline Dracos and Seta, ${ }^{30} 1998$ & $\begin{array}{l}\text { Sponsorship and conflict of interest not disclosed on Italian } \\
\text { sites }\end{array}$ & 17 & 30 & 56.7 & $d$ \\
\hline $\begin{array}{l}\text { Galimberti and Jain, }{ }^{37} \\
2000\end{array}$ & $\begin{array}{l}\text { Sites about hysterectomy where source of funding, form of } \\
\text { sponsorship, financial support, or publicity could not be } \\
\text { clearly identified }\end{array}$ & 16 & 26 & 61.5 & $d$ \\
\hline $\begin{array}{l}\text { Griffiths and } \\
\text { Christensen, }{ }^{42} 2000\end{array}$ & Sponsorship not disclosed on depression sites & 18 & 21 & 86 & $d$ \\
\hline Hatfield et $\mathrm{al}^{45} 1999$ & No sponsorship disclosure on drug information sites & 1 & 4 & 25.0 & $d$ \\
\hline Hersh et al, ${ }^{48} 1998$ & No financial and other support clearly indicated & 623 & 629 & 99.0 & $d$ \\
\hline \multicolumn{5}{|l|}{$\begin{array}{l}\text { Disclosure: Advertising Distinct } \\
\text { From Contents }\end{array}$} & e \\
\hline Kihlstrom, ${ }^{53} 2001$ & $\begin{array}{l}\text { Pharmacy benefit management sites with advertising where "it } \\
\text { was difficult to clearly differentiate the PBM site from the } \\
\text { outside advertising" }\end{array}$ & 8 & 8 & 100 & e \\
\hline $\begin{array}{l}\text { Tu and Zimmerman, }{ }^{86} \\
2001\end{array}$ & $\begin{array}{l}\text { Advertisements not distinct from content on eating disorder } \\
\text { sites }\end{array}$ & 27 & 97 & 27.8 & e \\
\hline $\begin{array}{l}\text { Disclosure: Partnership } \\
\quad \text { Gillois et al, }{ }^{39} 1999\end{array}$ & $\begin{array}{l}\text { Cardiovascular risk prediction sites with "no partnerships } \\
\text { identified" }\end{array}$ & 1 & 8 & 12.5 & \\
\hline
\end{tabular}


Online Table B. Overview of Quality Criteria Used by Studies and Their Evaluation Results* (cont)

\begin{tabular}{|c|c|c|c|c|c|}
\hline Study, Year & Description & $\begin{array}{l}\text { Not } \\
\text { complying }\end{array}$ & Total & $\begin{array}{c}\text { Not } \\
\text { Complying, \% }\end{array}$ & MA† \\
\hline $\begin{array}{l}\text { Disclosure: Conflict of Interest } \\
\text { Hersh et al, }{ }^{48} 1998\end{array}$ & No disclosure of potential conflicts of interest & 559 & 629 & 88.9 & \\
\hline $\begin{array}{l}\text { Disclosure: Statement of } \\
\text { Purpose } \\
\text { Diering and Palmer, }{ }^{28} 2001\end{array}$ & $\begin{array}{l}\text { Sites on urinary incontinence from professional organizations } \\
\text { with "purpose not stated" }\end{array}$ & 1 & 15 & 7 & $f$ \\
\hline Kihlstrom, ${ }^{53} 2001$ & $\begin{array}{l}\text { Pharmacy benefit management sites where "it was not } \\
\text { possible to determine the sites purpose within two clicks } \\
\text { of the mouse" }\end{array}$ & 7 & 71 & 10 & f \\
\hline Tu and Zimmerman, ${ }^{86} 2001$ & Sites on eating disorders not providing disclaimer on purpose & 85 & 97 & 87.6 & $f$ \\
\hline Türp et al, ${ }^{87} 2001$ & $\begin{array}{l}\text { DISCERN item 1: Aims not clear (Web pages on } \\
\text { myoarthropathies of the mastication system) }\end{array}$ & 26 & 47 & 55.3 & f \\
\hline $\begin{array}{l}\text { General Disclosures } \\
\text { Chen et } a l,{ }^{23} 2000\end{array}$ & $\begin{array}{l}\text { "Accountability criteria (disclosure of author's name, author's } \\
\text { credentials, evidence for claims or copyright, Web site } \\
\text { owner and the date the content was posted) not satisfied" }\end{array}$ & 59 & 141 & 42 & g \\
\hline O’Mahony, ${ }^{67} 1999$ & $\begin{array}{l}\text { No disclosure of site ownership, sponsorship, advertising, } \\
\text { commercial funding arrangements, or support on Irish } \\
\text { health care Web sites. }\end{array}$ & 49 & 60 & 81.7 & g \\
\hline Shon and Musen, ${ }^{76} 1999$ & No disclosure on site & 40 & 97 & 41 & g \\
\hline \multicolumn{6}{|l|}{$\begin{array}{l}\text { Currency of Information: Date } \\
\text { of Creation Disclosed }\end{array}$} \\
\hline $\begin{array}{l}\text { Doupi and van der Lei, }{ }^{29} \\
1999\end{array}$ & $\begin{array}{l}\text { No date on when information was written on drug information } \\
\text { sites }\end{array}$ & 14 & 14 & 100 & $\mathrm{~h}$ \\
\hline $\begin{array}{l}\text { Hoffman-Goetz and } \\
\text { Clarke, }{ }^{49} 2000\end{array}$ & $\begin{array}{l}\text { Breast cancer sites that did not disclose when page was } \\
\text { created }\end{array}$ & 117 & 136 & 86 & $\mathrm{~h}$ \\
\hline Pandolfini et al, ${ }^{70} 2000$ & Did not supply year of creation (range 93-97) & 7 & 19 & 36.8 & $\mathrm{~h}$ \\
\hline Türp et al, ${ }^{87} 2001$ & $\begin{array}{l}\text { DISCERN item 5: not clear when the information used or } \\
\text { reported in the publication was produced (Web pages on } \\
\text { myoarthropathies of the mastication system) }\end{array}$ & 43 & 47 & 91.5 & $\mathrm{~h}$ \\
\hline \multicolumn{5}{|l|}{$\begin{array}{l}\text { Currency of Information: First } \\
\text { Posted Disclosed }\end{array}$} & \\
\hline von Danwitz et al, ${ }^{91} 1999$ & "Date of publication" not clear & 19 & 39 & 49 & \\
\hline \multicolumn{6}{|l|}{$\begin{array}{l}\text { Currency of Information: Any of } \\
\text { Creation/First Posted } \\
\text { Disclosed }\end{array}$} \\
\hline \multicolumn{6}{|l|}{$\begin{array}{l}\text { Currency of Information: Last } \\
\text { Update Disclosed }\end{array}$} \\
\hline $\begin{array}{l}\text { Doupi and van der Lei, }{ }^{29} \\
1999\end{array}$ & No revision date on drug information sites & 9 & 14 & 64.2 & i \\
\hline Dracos and Seta, ${ }^{30} 1998$ & No dates disclosed on Italian sites & 17 & 30 & 56.7 & $\mathrm{i}$ \\
\hline $\begin{array}{l}\text { Hernández-Borges et al, }{ }^{47} \\
1999\end{array}$ & $\begin{array}{l}\text { No information on last update given [of those which gave the } \\
\text { information, they had been updated } 47.5 \text { weeks before } \\
\text { (range, 0-395)] }\end{array}$ & 189 & 363 & 52 & $\mathrm{i}$ \\
\hline $\begin{array}{l}\text { Hoffman-Goetz and } \\
\text { Clarke, }{ }^{49} 2000\end{array}$ & $\begin{array}{l}\text { Breast cancer sites which did not disclose when page was } \\
\text { updated }\end{array}$ & 91 & 136 & 66.9 & $\mathrm{i}$ \\
\hline Pandolfini et $\mathrm{al}^{70} 2000$ & Did not supply date modified & 15 & 19 & 78.9 & $\mathrm{i}$ \\
\hline Stausberg et al, ${ }^{81} 2001$ & $\begin{array}{l}\text { Web presentations of German surgical departments with no } \\
\text { indication of last update }\end{array}$ & 106 & 171 & 62 & $\mathrm{i}$ \\
\hline
\end{tabular}


Online Table B. Overview of Quality Criteria Used by Studies and Their Evaluation Results* (cont)

\begin{tabular}{|c|c|c|c|c|c|}
\hline Study, Year & Description & $\begin{array}{c}\text { Not } \\
\text { complying }\end{array}$ & Total & $\begin{array}{c}\text { Not } \\
\text { Complying, } \%\end{array}$ & MA† \\
\hline $\begin{array}{l}\text { Currency of Information: Any of } \\
\text { Creation/Update Disclosed } \\
\text { Hersh et al, }{ }^{48} 1998\end{array}$ & No date of posting/update given & 517 & 629 & 82.9 & j \\
\hline Jiang, ${ }^{52} 2000$ & Orthodontics sites without date posted or last updated & 56 & 70 & 80 & j \\
\hline Kihlstrom, ${ }^{53} 2001$ & $\begin{array}{l}\text { Pharmacy benefit management sites where "it was impossible } \\
\text { to tell if the information was current" }\end{array}$ & 61 & 71 & 85.9 & j \\
\hline Latthe et $a l,{ }^{55} 2000$ & No date of creation, posting, update or revision & 15 & 32 & 46.9 & j \\
\hline Latthe et al, ${ }^{56} 2000$ & $\begin{array}{l}\text { No date of the original document or date when content was } \\
\text { posted }\end{array}$ & 7 & 12 & 58 & j \\
\hline Libertiny et al, ${ }^{58} 2000$ & $\begin{array}{l}\text { Sites about varicose veins surgery bearing no date (1 } \\
\text { published in 1995, } 2 \text { in 1996, } 2 \text { in 1997, } 2 \text { in 1998, } 9 \text { in } \\
\text { 1999) }\end{array}$ & 25 & 41 & 61.0 & j \\
\hline $\begin{array}{l}\text { Martinez-Lopez and } \\
\quad \text { Ruiz-Crespo, }{ }^{61} 1998\end{array}$ & $\begin{array}{l}\text { Date of publication not provided on pages about rotator cuff } \\
\text { rupture }\end{array}$ & 9 & 57 & 15.8 & j \\
\hline O’Mahony, ${ }^{67} 1999$ & $\begin{array}{l}\text { No details of the date content was posted or updated on Irish } \\
\text { health care Web sites [of the } 25 \text { sites which gave this } \\
\text { information, } 10 \text { sites (17\%) had not been updated in the } \\
\text { last } 6 \text { months] }\end{array}$ & 35 & 60 & 58.3 & j \\
\hline Sandvik, ${ }^{75} 1999$ & Date of publication or last update not provided & 32 & 75 & 42.7 & j \\
\hline Shon and Musen, ${ }^{76} 1999$ & Neither date nor copyright with date listed & 61 & 97 & 36 & j \\
\hline $\begin{array}{l}\text { Stausberg and Fuchs, } \\
2000\end{array}$ & $\begin{array}{l}\text { Web presentations of German surgical departments with no } \\
\text { indication of creation or last update }\end{array}$ & 43 & 184 & 23.3 & j \\
\hline Tamm et $\mathrm{al},{ }^{84} 2000$ & Date of publication or last update not provided & 9 & 38 & 23.7 & j \\
\hline \multirow[t]{2}{*}{$\begin{array}{l}\text { Currency of Information: Sites } \\
\text { Modified in the Past } 6 \text { mo } \\
\text { Berland et al, }{ }^{15} 2001\end{array}$} & English dated Web sites not created or updated in past year & ? & ? & 54 & \\
\hline & Spanish dated Web sites not created or updated in past year & $?$ & $?$ & 83 & \\
\hline $\begin{array}{l}\text { Griffiths and } \\
\text { Christensen, }{ }^{42} 2000\end{array}$ & Depression sites not modified in the past month & 12 & 21 & 57 & \\
\hline Stausberg et al, ${ }^{81} 2001$ & $\begin{array}{l}\text { Web presentations of German surgical departments with } \\
\text { update more than } 6 \text { months ago (of those sites disclosing } \\
\text { update date) }\end{array}$ & 14 & 65 & 21.5 & \\
\hline $\begin{array}{l}\text { Stausberg and Fuchs, } \\
2000\end{array}$ & $\begin{array}{l}\text { Web presentations of German surgical departments not } \\
\text { updated in } 1999 \text { (as of September 1999) (of those sites } \\
\text { disclosing update date) }\end{array}$ & 31 & 141 & 22 & \\
\hline $\begin{array}{l}\text { Currency of Information: } \\
\text { Technical Maintenance } \\
\text { Date Disclosed } \\
\text { von Danwitz et al, },^{91} 1999 \\
\end{array}$ & No date of technical maintenance disclosed & 21 & 39 & 54 & \\
\hline $\begin{array}{l}\text { Currency of Information: Other } \\
\text { Butzke and Kramer, }{ }^{21} 2000\end{array}$ & $\begin{array}{l}\text { Orthopedic department homepages "not updated sufficiently" } \\
\text { (definition unclear) }\end{array}$ & $?$ & $\begin{array}{l}42 \text { (or } \\
125 ?)\end{array}$ & 54 & \\
\hline Diering and Palmer, ${ }^{28} 2001$ & $\begin{array}{l}\text { Sites on urinary incontinence from professional organizations } \\
\text { with "date not listed or information that was evaluated as } \\
\text { out of date" }\end{array}$ & 6 & 15 & 40 & \\
\hline Groot et al, ${ }^{43} 2001$ & $\begin{array}{l}\text { Sites not fulfilling the "currency" criterion [unclear how this was } \\
\text { evaluated] }\end{array}$ & 27 & 36 & 75 & \\
\hline $\begin{array}{l}\text { Martinez-Lopez and } \\
\quad \text { Ruiz-Crespo, }{ }^{61} 1998\end{array}$ & $\begin{array}{l}\text { Information on pages about rotator cuff rupture is "static," ie, } \\
\text { not periodically updated (unclear, how this was determined } \\
\text { by raters) }\end{array}$ & 30 & 57 & 52.6 & \\
\hline $\begin{array}{l}\text { Authority of Source: Credibility } \\
\text { of Source (Source Rating) } \\
\text { Eachus, }{ }^{31} 1999\end{array}$ & "Less credible sources" among coronary heart disease sites & 36 & 86 & 41.9 & \\
\hline $\begin{array}{l}\text { Roberts and Spooner, }{ }^{73} \\
1997\end{array}$ & Reliability of author (no one responsible, suspicious) & 45 & 300 & 15.0 & \\
\hline
\end{tabular}


Online Table B. Overview of Quality Criteria Used by Studies and Their Evaluation Results* (cont)

\begin{tabular}{|c|c|c|c|c|c|}
\hline Study, Year & Description & $\begin{array}{l}\text { Not } \\
\text { complying }\end{array}$ & Total & $\begin{array}{c}\text { Not } \\
\text { Complying, \% }\end{array}$ & MA† \\
\hline \multicolumn{6}{|l|}{$\begin{array}{l}\text { Authority of Source: Author } \\
\text { Credentials }\end{array}$} \\
\hline $\begin{array}{l}\text { Butzke and Kramer, }{ }^{21} \\
2000\end{array}$ & $\begin{array}{l}\text { No information on "authority and qualification of author" on } \\
\text { orthopedic department home pages with medical } \\
\text { information }\end{array}$ & 31 & 42 & 73.8 & k \\
\hline $\begin{array}{l}\text { Diering and Palmer, }{ }^{28} \\
2001\end{array}$ & $\begin{array}{l}\text { Sites on urinary incontinence from professional organizations } \\
\text { with "no author/organization credentials listed" }\end{array}$ & 1 & 15 & 7 & k \\
\hline $\begin{array}{l}\text { Doupi and van der Lei, }{ }^{29} \\
1999\end{array}$ & No/insufficient provision of authors' credentials & 6 & 14 & 42.9 & k \\
\hline $\begin{array}{l}\text { Griffiths and } \\
\quad \text { Christensen, }{ }^{42} 2000\end{array}$ & Authors' credentials not disclosed on depression sites & 10 & 21 & 48.6 & k \\
\hline Hersh et al, ${ }^{48} 1998$ & No credentials of authors indicated & 509 & 629 & 80.9 & k \\
\hline $\begin{array}{l}\text { Hoffman-Goetz and } \\
\text { Clarke, }{ }^{49} 2000\end{array}$ & $\begin{array}{l}\text { Breast cancer sites where credentials of site owner could not } \\
\text { be identified }\end{array}$ & 93 & 136 & 68.4 & k \\
\hline $\begin{array}{l}\text { Martinez-Lopez and } \\
\quad \text { Ruiz-Crespo, }{ }^{61} 1998 \\
\end{array}$ & $\begin{array}{l}\text { No information on qualification or workplace of the author } \\
\text { given on pages about rotator cuff rupture }\end{array}$ & 10 & 57 & 17.5 & k \\
\hline Pandolfini et al, ${ }^{70} 2000$ & No credentials of authors listed & 7 & 19 & 36.8 & k \\
\hline Shon and Musen, ${ }^{76} 1999$ & No credentials of authors listed & 60 & 97 & 62 & k \\
\hline \multicolumn{6}{|l|}{$\begin{array}{l}\text { Authority of Source: } \\
\text { Credentials of Consulting } \\
\text { Physicians }\end{array}$} \\
\hline Armstrong et al, ${ }^{12} 1999$ & $\begin{array}{l}\text { Sites selling sildanefil offering online medical evaluation by a } \\
\text { physician without providing specific information about the } \\
\text { qualifications of the physician }\end{array}$ & 27 & 27 & 100 & 1 \\
\hline $\begin{array}{l}\text { Bloom and lannacone, }{ }^{17} \\
1999\end{array}$ & $\begin{array}{l}\text { Sites selling prescription drugs without revealing address, } \\
\text { name, specialty, location, or qualification of consulting } \\
\text { physician doing online medical evaluation }\end{array}$ & 37 & 37 & 100 & I \\
\hline Kihlstrom, ${ }^{53} 2001$ & $\begin{array}{l}\text { Pharmacy benefit management sites that offer medical advice } \\
\text { without clearly identifying the credentials of the individuals } \\
\text { offering such advice }\end{array}$ & 15 & 17 & 88.2 & 1 \\
\hline \multicolumn{6}{|l|}{$\begin{array}{l}\text { Authority of Source: Not } \\
\text { Provided by Health } \\
\text { Professional/Specialists }\end{array}$} \\
\hline $\begin{array}{l}\text { Galimberti and Jain, } \\
2000 \\
\end{array}$ & $\begin{array}{l}\text { Sites about hysterectomy not provided by health professional, } \\
\text { or no disclosure of this fact }\end{array}$ & 10 & 26 & 38.5 & \\
\hline $\begin{array}{l}\text { Martinez-Lopez and } \\
\quad \text { Ruiz-Crespo, }{ }^{61} 1998\end{array}$ & $\begin{array}{l}\text { Pages about rotator cuff tear where raters had an "objection" } \\
\text { against the qualification of the author, ie, they are not } \\
\text { physician specialists }\end{array}$ & 10 & 57 & 17.5 & \\
\hline \multicolumn{6}{|l|}{$\begin{array}{l}\text { Authority of Source: Authors' } \\
\text { Affiliations }\end{array}$} \\
\hline $\begin{array}{l}\text { Doupi and van der Lei, }{ }^{29} \\
1999\end{array}$ & No/insufficient provision of authors' affiliations & 4 & 14 & 28.6 & $\mathrm{~m}$ \\
\hline $\begin{array}{l}\text { Griffiths and } \\
\quad \text { Christensen, }{ }^{42} 2000 \\
\end{array}$ & Authors' affiliations not disclosed on depression sites & 10 & 21 & 48.6 & $\mathrm{~m}$ \\
\hline Hersh et al, ${ }^{48} 1998$ & No affiliation of site clearly indicated & 293 & 629 & 46.6 & $\mathrm{~m}$ \\
\hline O’Mahony, ${ }^{67} 1999$ & $\begin{array}{l}\text { No authors' affiliations and credentials on Irish health } \\
\text { information providers }\end{array}$ & 14 & 18 & 77.8 & $\mathrm{~m}$ \\
\hline $\begin{array}{c}\text { Shon and Musen, }{ }^{76} 1999 \\
\end{array}$ & No affiliation on page & 10 & 97 & 10 & $\mathrm{~m}$ \\
\hline $\begin{array}{l}\text { Ease of Use: Navigation } \\
\quad \text { Diering and Palmer, }{ }^{28} 2001\end{array}$ & $\begin{array}{l}\text { Sites on urinary incontinence from professional organizations } \\
\text { with "no easy navigation" }\end{array}$ & 1 & 15 & 7 & $\mathrm{n}$ \\
\hline Sandvik, ${ }^{75} 1999$ & Navigability insufficient (information scattered around) & 1 & 75 & 1.3 & $\mathrm{n}$ \\
\hline Stausberg and Fuchs, ${ }^{80} 2000$ & $\begin{array}{l}\text { Insufficient navigation on Web sites of German surgical } \\
\text { departments }\end{array}$ & 31 & 184 & 16.8 & $\mathrm{n}$ \\
\hline Voiglio et al, ${ }^{90} 1999$ & $\begin{array}{l}\text { Anatomy sites where navigability ("aptitude of the site to allow } \\
\text { good circulation within the site and toward other sites") } \\
\text { was rated } 0 \text { (on a scale 0-5) }\end{array}$ & 0 & 52 & 0 & $\mathrm{n}$ \\
\hline
\end{tabular}


Online Table B. Overview of Quality Criteria Used by Studies and Their Evaluation Results* (cont)

\begin{tabular}{|c|c|c|c|c|c|}
\hline Study, Year & Description & $\begin{array}{c}\text { Not } \\
\text { complying }\end{array}$ & Total & $\begin{array}{c}\text { Not } \\
\text { Complying, \% }\end{array}$ & MA† \\
\hline $\begin{array}{l}\text { Ease of Use: Navigation Depth } \\
\quad \text { Kihlstrom, }{ }^{3} 2001\end{array}$ & $\begin{array}{l}\text { Pharmacy benefit management sites which "were constructed } \\
\text { using more than two levels beyond the homepage" }\end{array}$ & 35 & 71 & 50 & \\
\hline $\begin{array}{l}\text { Ease of Use: Search Engine } \\
\text { Breul et al, }{ }^{20} 1999\end{array}$ & No search engine on French hospital sites & 60 & 68 & 88 & 0 \\
\hline Diering and Palmer, ${ }^{28} 2001$ & $\begin{array}{l}\text { Sites on urinary incontinence from professional organizations } \\
\text { with no internal search engine }\end{array}$ & 7 & 15 & 47 & 0 \\
\hline Gillois et al, ${ }^{39} 1999$ & Cardiovascular risk prediction sites with no search engine & 5 & 8 & 62.5 & o \\
\hline $\begin{array}{l}\text { Ease of Use: Search Functionality } \\
\quad \text { Gillois et al, } 1999\end{array}$ & Cardiovascular risk prediction sites with "no simple browsing" & 1 & 8 & 12.5 & \\
\hline Willems and Bouvy, ${ }^{93} 2001$ & Search functionality: sites rated "bad" on 5-point scale & 1 & 23 & 4.3 & \\
\hline $\begin{array}{l}\text { User Support: Navigation Aids } \\
\text { Breul et } \mathrm{al}^{20} 1999\end{array}$ & No navigation aids on French hospital sites & 10 & 68 & 15 & \\
\hline $\begin{array}{l}\text { Martinez-Lopez and } \\
\quad \text { Ruiz-Crespo, }{ }^{61} 1998\end{array}$ & $\begin{array}{l}\text { Pages about rotator cuff rupture with insufficient navigation } \\
\text { aids (index, table of contents, or icons for navigation) }\end{array}$ & 13 & 57 & 22.8 & \\
\hline $\begin{array}{l}\text { User Support: Site Map } \\
\text { Breul et al, }{ }^{20} 1999\end{array}$ & No site map on French hospital sites & 10 & 68 & 15 & \\
\hline Kihlstrom, ${ }^{53} 2001$ & Pharmacy benefit management sites not offering a site map & 4 & 71 & 5.6 & \\
\hline $\begin{array}{l}\text { User Support: Documentation } \\
\text { Breul et al, }{ }^{20} 1999\end{array}$ & No help files on French hospital sites & 68 & 68 & 100 & \\
\hline $\begin{array}{l}\text { User Support: What's New } \\
\text { Breul et al }{ }^{20} 1999\end{array}$ & No "What's New" section on French hospital sites & 44 & 68 & 84 & \\
\hline $\begin{array}{l}\text { Accessibility and Availability: } \\
\text { Speed } \\
\text { von Danwitz et al, }{ }^{91} 1999\end{array}$ & Speed: takes more than 10 sec to build up & 5 & 39 & 95 & \\
\hline $\begin{array}{l}\text { Accessibility and Availability: } \\
\text { Browser Compatibility } \\
\text { von Danwitz et al, }{ }^{91} 1999\end{array}$ & Sites not browser compatible & 3 & 39 & 8 & \\
\hline $\begin{array}{l}\text { Accessibility and Availability: } \\
\text { Language } \\
\text { Breul et al, }{ }^{20} 1999\end{array}$ & French hospital sites not available in more than 1 language & 56 & 68 & 82 & \\
\hline $\begin{array}{c}\text { Accessibility and Availability: } \\
\text { Cited in Search Engines } \\
\text { Breul et al, }{ }^{20} 1999 \\
\end{array}$ & French hospital sites not cited in a search engine & 0 & 68 & 0 & \\
\hline $\begin{array}{l}\text { Accessibility and Availability: } \\
\text { Cited on Other Sites } \\
\text { Breul et al, }{ }^{20} 1999\end{array}$ & French hospital sites not cited on other sites & 0 & 68 & 0 & \\
\hline $\begin{array}{l}\text { Links: Links Present } \\
\text { Breul et } \mathrm{al}^{20} 1999\end{array}$ & No "pertinent links" on French hospital sites & 22 & 68 & 33 & $\mathrm{p}$ \\
\hline Diering and Palmer, ${ }^{28} 2001$ & $\begin{array}{l}\text { Sites on urinary incontinence from professional organizations } \\
\text { with "no links or dead links" }\end{array}$ & 0 & 15 & 0 & $\mathrm{p}$ \\
\hline $\begin{array}{l}\text { Hoffman-Goetz and Clarke, }{ }^{49} \\
2000\end{array}$ & Breast cancer sites that did not provide links & 29 & 136 & 21 & $\mathrm{p}$ \\
\hline Pandolfini et $\mathrm{al}_{1}{ }^{70} 2000$ & Did not provide links relevant to cough & 15 & 19 & 78.9 & $\mathrm{p}$ \\
\hline $\begin{array}{l}\text { Links: Broken Links } \\
\text { Martinez-Lopez and } \\
\text { Ruiz-Crespo, }{ }^{61} 1998\end{array}$ & $\begin{array}{l}\text { Pages about rotator cuff rupture with incorrect URLs (broken } \\
\text { links) }\end{array}$ & 11 & 57 & 19.3 & \\
\hline
\end{tabular}


Online Table B. Overview of Quality Criteria Used by Studies and Their Evaluation Results* (cont)

\begin{tabular}{|c|c|c|c|c|c|}
\hline Study, Year & Description & $\begin{array}{c}\text { Not } \\
\text { complying }\end{array}$ & Total & $\begin{array}{c}\text { Not } \\
\text { Complying, \% }\end{array}$ & MA† \\
\hline \multicolumn{6}{|l|}{$\begin{array}{l}\text { Attribution and Documentation: } \\
\text { References }\end{array}$} \\
\hline Abbott, ${ }^{11} 2000$ & No references on pages about MMR vaccine & 34 & 40 & 85.0 & q \\
\hline Biermann et al, ${ }^{16} 1999$ & $\begin{array}{l}\text { No reference source (including no reference to peer-review) } \\
\text { listed on Web pages about Ewing Sarcoma }\end{array}$ & 57 & 165 & 34.5 & q \\
\hline $\begin{array}{l}\text { Butzke and Kramer, }{ }^{21} \\
2000\end{array}$ & $\begin{array}{l}\text { No information about the source of medical information on } \\
\text { orthopedic department homepages }\end{array}$ & 14 & 42 & 33.3 & q \\
\hline Bykowski et al, 222000 & $\begin{array}{l}\text { Cutaneous laser surgery Web sites without references to } \\
\text { peer-reviewed publications or research }\end{array}$ & 40 & 40 & 100 & q \\
\hline Chen et $\mathrm{al}_{,}{ }^{23} 2000$ & No "referral to a reliable source of information" & 103 & 131 & 79 & q \\
\hline Corpron and Lelli, ${ }^{24} 2001$ & $\begin{array}{l}\text { Sites about ambiguous genitalia not "referencing their source } \\
\text { of information" }\end{array}$ & 8 & 8 & 100 & q \\
\hline $\begin{array}{l}\text { Diering and Palmer, }{ }^{28} \\
2001\end{array}$ & $\begin{array}{l}\text { Sites on urinary incontinence from professional organizations } \\
\text { with "references not cited" }\end{array}$ & 3 & 15 & 20 & q \\
\hline $\begin{array}{l}\text { Doupi and van der Lei, }{ }^{29} \\
1999\end{array}$ & No/insufficient references on drug information sites & 12 & 14 & 85.7 & q \\
\hline Dracos and Seta, ${ }^{30} 1998$ & No references on Italian sites & 17 & 30 & 56.7 & q \\
\hline $\begin{array}{l}\text { Galimberti and Jain, }{ }^{37} \\
2000\end{array}$ & Sites about hysterectomy not "properly referenced" & 6 & 26 & 23.1 & q \\
\hline Gillois et al, ${ }^{39} 1999$ & Cardiovascular risk prediction sites with no references & 3 & 7 & 42.9 & q \\
\hline $\begin{array}{l}\text { Griffiths and } \\
\quad \text { Christensen, }{ }^{42} 2000\end{array}$ & References not given on depression sites & 12 & 21 & 57.1 & q \\
\hline Hatfield et al, ${ }^{45} 1999$ & No references on drug information sites & 1 & 4 & 25.0 & $\mathrm{q}$ \\
\hline \multirow[t]{2}{*}{ Hellawell et al, ${ }^{46} 2000$} & $\begin{array}{l}\text { Sites about prostate cancer not providing conventional } \\
\text { references }\end{array}$ & 37 & 50 & 74 & q \\
\hline & $\begin{array}{l}\text { Sites about testicular cancer not providing conventional } \\
\text { references }\end{array}$ & 34 & 50 & 68 & q \\
\hline Hersh et al, ${ }^{48} 1998$ & No sources, bibliography listed & 552 & 629 & 87.8 & q \\
\hline $\begin{array}{l}\text { Hoffman-Goetz and } \\
\text { Clarke, }{ }^{49} 2000\end{array}$ & $\begin{array}{l}\text { Breast cancer sites that did not "identify sources for } \\
\text { information" (as opposed to those identifying experts with } \\
\text { credentials) }\end{array}$ & 95 & 136 & 69.9 & q \\
\hline Jiang, ${ }^{52} 2000$ & Orthodontics sites with no references related to the content & 60 & 70 & 85.7 & q \\
\hline \multirow[t]{2}{*}{ Li et al, ${ }^{57} 2001$} & $\begin{array}{l}\text { Sites about back pain rated "not providing an independent } \\
\text { way to verify info (eg, a reference list)" (September 1996) }\end{array}$ & 46 & 73 & 63.0 & q \\
\hline & $\begin{array}{l}\text { Sites about back pain rated "not providing an independent } \\
\text { way to verify info (eg, a reference list)" (February 1999) }\end{array}$ & 34 & 54 & 63.0 & q \\
\hline Libertiny et al, ${ }^{58} 2000$ & $\begin{array}{l}\text { Sites about varicose veins surgery with no "conventional } \\
\text { references" }\end{array}$ & 38 & 41 & 92.7 & q \\
\hline $\begin{array}{l}\text { Martinez-Lopez and } \\
\quad \text { Ruiz-Crespo, }{ }^{61} 1998\end{array}$ & Pages about rotator cuff rupture not providing a bibliography & 32 & 57 & 56.1 & q \\
\hline O’Mahony, ${ }^{67} 1999$ & $\begin{array}{l}\text { No references or sources given on sites of Irish health } \\
\text { information providers }\end{array}$ & 13 & 18 & 72.2 & q \\
\hline Pandolfini et $\mathrm{al}^{70} 2000$ & No references & 16 & 19 & 84.2 & q \\
\hline Sandvik, 1999 & No indication of source & 50 & 75 & 66.7 & $\mathrm{q}$ \\
\hline Shon and Musen, ${ }^{76} 1999$ & $\begin{array}{l}\text { References not listed (if references were applicable, which was } \\
\text { the case in 20\%) }\end{array}$ & 66 & 97 & 68 & q \\
\hline \multirow[t]{2}{*}{ Soot et al, ${ }^{79} 1999$} & $\begin{array}{l}\text { No conventional references on pages which are able to } \\
\text { reference }\end{array}$ & 19 & 108 & 17.6 & q \\
\hline & (No conventional references, in relation to all pages) & $(57)$ & $(146)$ & (39.0) & $\mathrm{q}$ \\
\hline Tamm et al, 2000 & No references & 11 & 38 & 28.9 & q \\
\hline $\begin{array}{l}\text { Veronin and Ramirez, } \\
2000\end{array}$ & $\begin{array}{l}\text { No references or single reference }(n=7) \text { on sites providing } \\
\text { information about Opuntia }\end{array}$ & 152 & 184 & 82.6 & q \\
\hline von Danwitz et al. ${ }^{91} 1999$ & No sources cited & 7 & 39 & 18 & q \\
\hline
\end{tabular}




\begin{tabular}{|c|c|c|c|c|c|}
\hline Study, Year & Description & $\begin{array}{l}\text { Not } \\
\text { complying }\end{array}$ & Total & $\begin{array}{c}\text { Not } \\
\text { Complying, } \%\end{array}$ & MA† \\
\hline $\begin{array}{l}\text { Attribution and Documentation: } \\
\text { Further Information or Links } \\
\text { Galimberti and Jain, } \\
2000\end{array}$ & $\begin{array}{l}\text { Sites about hysterectomy not providing "contact addresses, } \\
\text { links, or sources for further information" }\end{array}$ & 6 & 26 & 23.1 & \\
\hline $\begin{array}{l}\text { Attribution and Documentation: } \\
\text { Balanced Evidence } \\
\text { Gordon et al, }{ }^{40} 2001\end{array}$ & $\begin{array}{l}\text { Breast augmentation sites with photographs showing either } \\
\text { only good ( } 74 \% \text { ) or only bad results (11\%) (none of the } \\
\text { physician sites showed bad results) }\end{array}$ & 16 & 19 & 84 & \\
\hline & $\begin{array}{l}\text { Breast augmentation sites judged as being biased toward a } \\
\text { particular technique }\end{array}$ & 34 & 41 & 82 & r \\
\hline Sandvik, ${ }^{75} 1999$ & Sites providing unbalanced information & 15 & 75 & 20 & $r$ \\
\hline Türp et al, ${ }^{87} 2001$ & $\begin{array}{l}\text { DISCERN item 6: Unbalanced or biased (Web pages on } \\
\text { myoarthropathies of the mastication system) }\end{array}$ & 29 & 47 & 61.7 & r \\
\hline \multicolumn{6}{|l|}{$\begin{array}{l}\text { Attribution and Documentation: } \\
\text { Omissions Noted }\end{array}$} \\
\hline $\begin{array}{l}\text { Tu and Zimmerman, }{ }^{86} \\
2001 \\
\end{array}$ & Omissions not noted on eating disorder sites & 95 & 97 & 97.9 & \\
\hline $\begin{array}{l}\text { Attribution and Documentation: } \\
\text { Limitations Noted } \\
\text { Martinez-Lopez and } \\
\text { Ruiz-Crespo, }{ }^{61} 1998\end{array}$ & $\begin{array}{l}\text { Pages about new techniques or theories about rotator cuff } \\
\text { rupture where limitations were not discussed }\end{array}$ & 12 & 57 & 21.1 & \\
\hline \multicolumn{6}{|l|}{$\begin{array}{l}\text { Intended Audience: Target } \\
\text { Audience Disclosed }\end{array}$} \\
\hline $\begin{array}{l}\text { Willems and Bouvy, }{ }^{93} \\
2001 \\
\end{array}$ & Target audience clear: sites rated "bad" on 5-point scale & 0 & 23 & 0 & \\
\hline $\begin{array}{l}\text { Intended Audience: Multiple } \\
\text { Target Audiences } \\
\text { Kihlstrom, }{ }^{53} 2001\end{array}$ & $\begin{array}{l}\text { Pharmacy benefit management sites "targeting just one } \\
\text { audience" }\end{array}$ & 12 & 71 & 16.9 & \\
\hline $\begin{array}{l}\text { Readability: Readability } \\
\text { Formulas } \\
\text { Abbott, }{ }^{11} 2000\end{array}$ & $\begin{array}{l}\text { Flesch-Reading Ease Score, calculated using WordPerfect v8 } \\
\text { (no results reported) }\end{array}$ & & & & \\
\hline Berland et al, ${ }^{15} 2001$ & $\begin{array}{l}\text { English sites: Mean Fry Readability Graph (FRG) reading grade } \\
\quad \text { level } 13.2(\mathrm{SD}, 2.1) \\
\text { Mean SMOG 13.6 (SD, 0.9) } \\
\text { Lexile Framework } 11.7(\mathrm{SD}, 1.0) \\
\text { Spanish sites: } \\
\text { Mean FRG reading grade level } 9.9(\mathrm{SD}, 2.5) \\
\text { Lexile Framework } 10.0(\mathrm{SD}, 2.6)\end{array}$ & & & & \\
\hline D'Alessandro et al, ${ }^{25} 2001$ & $\begin{array}{l}89 \text { Documents:Mean Flesch Reading Ease score was } 57.0 \\
\text { Mean Fry Formula was } 12.0\left(12^{\text {th }} \text { grade, } 0 \text { months of }\right. \\
\quad \text { schooling) } \\
\text { Mean SMOG was } 12.2 \\
\text { Mean Flesch-Kincaid grade level was } 7.1\end{array}$ & & & & \\
\hline $\begin{array}{l}\text { Diering and Palmer, } \\
2001\end{array}$ & $\begin{array}{l}12 \text { Documents from } 11 \text { sites on urinary incontinence from } \\
\text { professional organizations: } \\
\text { Flesch Kinkaid Grade Level ranged from } 6.2 \text { to } 14.5 \text { years } \\
\text { (median 10.5) }\end{array}$ & & & & \\
\hline Estrada et $a l,{ }^{33} 2000$ & $\begin{array}{l}9 \text { patient information documents about atrial fibrillation and } \\
\text { warfarin from } 6 \text { different sites: } \\
\text { Flesch Kinkaid Grade Level ranged from } 8.6 \text { to } 11.8 \text { (median } \\
\text { 9.6) } \\
\text { SMOG Grade Level ranged from } 11.0 \text { to } 15.0 \text { (median 12.0) } \\
\text { Internet brochures had a significantly higher score than printed } \\
\text { brochures. }\end{array}$ & & & & \\
\hline $\begin{array}{l}\text { Fitzmaurice and Adams, } \\
2000 \\
\end{array}$ & $\begin{array}{l}\text { Gunning Fog Index, subjective marks for writing style (no } \\
\text { results reported). }\end{array}$ & & & & \\
\hline Graber et al, ${ }^{41} 1999$ & $\begin{array}{l}50 \text { patient education Web sites had a mean Flesch reading } \\
\text { score of } 47.1 \text { (median } 44.1 \text {; range } 25.7-70.3 \text { ) and a mean } \\
\text { Flesch-Kinkaid score of } 9.9 \text { (median } 10.2=10^{\text {th }} \text { grade } 2^{\text {nd }} \\
\text { month; range } 6.1-12 \text { ). Authors cite references that suggest } \\
\text { that } 70 \%-80 \% \text { of patients could not comprehend } \\
\text { information at such reading level }\end{array}$ & & & & \\
\hline
\end{tabular}


Online Table B. Overview of Quality Criteria Used by Studies and Their Evaluation Results* (cont)

\begin{tabular}{|c|c|c|c|c|c|}
\hline Study, Year & Description & $\begin{array}{c}\text { Not } \\
\text { complying }\end{array}$ & Total & $\begin{array}{c}\text { Not } \\
\text { Complying, } \%\end{array}$ & MA† \\
\hline \multicolumn{6}{|l|}{$\begin{array}{l}\text { Readability: Readability } \\
\text { Formulas (cont) }\end{array}$} \\
\hline Murphy et al, ${ }^{65} 2001$ & $\begin{array}{l}7 / 8 \text { (87.5\%) of Web information materials and } 31 / 35 \text { ( } 88.6 \%) \\
\text { of printed patient information was written above } 9^{\text {th }} \text {-grade } \\
\text { level (Fog index). The } 8 \text { patient education materials came } \\
\text { from only } 2 \text { different sites, so that it is questionable } \\
\text { whether this result is representative. }\end{array}$ & 7 & 8 & 87.5 & \\
\hline $\begin{array}{l}\text { Oermann and Wilson, }{ }^{66} \\
2000\end{array}$ & $\begin{array}{l}10 \text { documents about quality-of-care information for } \\
\text { consumers: Flesch-Kincaid Mean Grade Level Scores } \\
\text { ranged from } 7^{\text {th }}-12^{\text {th }} \text { grade (median } 8 \text { )"The overall mean } \\
\text { reading demands of four of the documents were higher } \\
\text { than the recommended } 8^{\text {th }} \text { level accepted for the public" } \\
\text { Most used active voice, minimal technical jargon, font size } \\
\text { from } 12-14 \text { points. None used illustrations or culturally } \\
\text { specific information. }\end{array}$ & 4 & 10 & 40 & \\
\hline O’Mahony, ${ }^{67} 1999$ & $\begin{array}{l}46 \text { Irish information service provider had a mean } \\
\text { Flesch-Kinkaid score of } 15.7 \text { years, (SD was } 2 \text { and the } \\
\text { median was 17). Seventy-six percent had a reading age in } \\
\text { excess of } 12 \text { to } 14 \text { years. }\end{array}$ & 35 & 46 & 76.1 & \\
\hline Wilson et al, ${ }^{94} 2000$ & $\begin{array}{l}\text { Mean Flesch-Kincaid reading level of } 49 \text { documents from PDQ } \\
\text { was } 12^{\text {th }} \text { grade }(S D, 2.91)\end{array}$ & & & & \\
\hline \multicolumn{6}{|l|}{$\begin{array}{l}\text { Readability: Subjective Ratings } \\
\text { of Writing Style }\end{array}$} \\
\hline Dracos and Seta, ${ }^{30} 1998$ & $\begin{array}{l}\text { Readability of Italian sites rated "not sufficient" (subjective } \\
\text { rating on 3-point scale) }\end{array}$ & 4 & 30 & 13 & s \\
\hline $\begin{array}{l}\text { Galimberti and Jain, }{ }^{37} \\
2000\end{array}$ & $\begin{array}{l}\text { Sites about hysterectomy rated not "to be clearly presented in } \\
\text { a legible way and in plain English with avoidance of } \\
\text { technical terminology or jargon" }\end{array}$ & 3 & 26 & 11.3 & s \\
\hline $\begin{array}{l}\text { Martinez-Lopez and } \\
\text { Ruiz-Crespo, }{ }^{61} 1998\end{array}$ & $\begin{array}{l}\text { The writing style of pages about rotator cuff rupture is not } \\
\text { "easy to read" (subjective rating yes/no) }\end{array}$ & 10 & 57 & 17.5 & $\mathrm{~s}$ \\
\hline $\begin{array}{l}\text { Willems and Bouvy, }{ }^{93} \\
2001\end{array}$ & $\begin{array}{l}\text { "Use of language": } 5 \text { Dutch sites rated "satisfactory" (worst } \\
\text { rating given) on 5-point scale (vs } 18 \text { "good") }\end{array}$ & 5 & 23 & 21.7 & $\mathrm{~s}$ \\
\hline \multicolumn{6}{|l|}{$\begin{array}{l}\text { Readability: Legibility } \\
\text { (Technical) }\end{array}$} \\
\hline Kihlstrom, ${ }^{53} 2001$ & $\begin{array}{l}\text { Pharmacy benefit management sites where "the print size was } \\
\text { too small to read easily" }\end{array}$ & 44 & 71 & 62 & \\
\hline \multirow[t]{2}{*}{$\begin{array}{l}\text { Martinez-Lopez and } \\
\quad \text { Ruiz-Crespo, }{ }^{61} 1998\end{array}$} & $\begin{array}{l}\text { Inadequate background (no sufficient contrast) on pages } \\
\text { about rotator cuff rupture }\end{array}$ & 24 & 57 & 42.1 & \\
\hline & $\begin{array}{l}\text { Document illegible due to "abuse of different fonts and } \\
\text { character sizes" or bad formatting of the text on pages } \\
\text { about rotator cuff rupture }\end{array}$ & 9 & 57 & 15.8 & \\
\hline \multicolumn{6}{|l|}{ Readability: Reading Levels } \\
\hline D’Alessandro et al, ${ }^{25} 2001$ & $\begin{array}{l}\text { Documents from pediatric patient education sites where } \\
\text { reading level was not noted on the document }\end{array}$ & 89 & 89 & 100 & \\
\hline \multicolumn{6}{|l|}{$\begin{array}{l}\text { Contact Addresses or } \\
\text { Feedback Mechanism: } \\
\text { Feedback Mechanisms } \\
\text { Provided }\end{array}$} \\
\hline Hatfield et al, ${ }^{45} 1999$ & No contact possibility for author on drug information sites & 4 & 4 & 100 & $\mathrm{t}$ \\
\hline Sandvik, ${ }^{75} 1999$ & No possibility for interactivity (e-mail or feedback form) & 0 & 75 & 0 & $\mathrm{t}$ \\
\hline \multirow[t]{2}{*}{ von Danwitz et al, ${ }^{91} 1999$} & No feedback possibility to Web master & 9 & 39 & 23 & $\mathrm{t}$ \\
\hline & No contact possibility editor/author & 9 & 39 & 23 & $\mathrm{t}$ \\
\hline \multicolumn{6}{|l|}{$\begin{array}{l}\text { Contact Addresses or } \\
\text { Feedback Mechanism: } \\
\text { Postal Address }\end{array}$} \\
\hline Breul et al, ${ }^{20} 1999$ & No mailing address on French hospital sites & 41 & 68 & 60 & \\
\hline $\begin{array}{l}\text { Ogushi and Tatsumi, }{ }^{68} \\
2000\end{array}$ & $\begin{array}{l}\text { Address of the information provider not stated clearly on } \\
\text { Japanese sites of medical institutions (hospitals, clinics) }\end{array}$ & 126 & 1147 & 11.2 & \\
\hline
\end{tabular}


Online Table B. Overview of Quality Criteria Used by Studies and Their Evaluation Results* (cont)

\begin{tabular}{|c|c|c|c|c|c|}
\hline Study, Year & Description & $\begin{array}{c}\text { Not } \\
\text { complying }\end{array}$ & Total & $\begin{array}{c}\text { Not } \\
\text { Complying, \% } \\
\end{array}$ & MA† \\
\hline \multicolumn{6}{|l|}{$\begin{array}{l}\text { Contact Addresses or } \\
\text { Feedback Mechanism: } \\
\text { Telephone }\end{array}$} \\
\hline Breul et al, ${ }^{20} 1999$ & No telephone number on French hospital sites & 46 & 68 & 67 & \\
\hline $\begin{array}{l}\text { Ogushi and Tatsumi, }{ }^{68} \\
2000\end{array}$ & $\begin{array}{l}\text { Telephone number not stated clearly on Japanese sites of } \\
\text { medical institutions (hospitals, clinics) }\end{array}$ & 145 & 1147 & 12.6 & \\
\hline \multicolumn{6}{|l|}{$\begin{array}{l}\text { Contact Addresses or } \\
\text { Feedback Mechanism: Fax } \\
\text { Breul et al, }{ }^{20} 1999\end{array}$} \\
\hline $\begin{array}{l}\text { Diering and Palmer, }{ }^{28} \\
2001\end{array}$ & $\begin{array}{l}\text { Sites on urinary incontinence from professional organizations } \\
\text { "not interactive" (meaning no e-mail address provided?) }\end{array}$ & 3 & 15 & 20 & u \\
\hline Kihlstrom, ${ }^{53} 2001$ & $\begin{array}{l}\text { Pharmacy benefit management sites not offering feedback } \\
\text { and e-mail }\end{array}$ & 9 & 71 & 12.7 & u \\
\hline $\begin{array}{l}\text { Ogushi and Tatsumi, }{ }^{68} \\
2000\end{array}$ & $\begin{array}{c}\text { Fax number of the information provider not stated clearly on } \\
\text { Japanese sites of medical institutions (hospitals, clinics) }\end{array}$ & 439 & 1147 & 38.3 & u \\
\hline $\begin{array}{l}\text { Thompson and Howard, }{ }^{85} \\
2000\end{array}$ & $\begin{array}{l}\text { HMO sites not containing "specific information and guidance } \\
\text { on a how to contact a customer service representative" }\end{array}$ & 0 & 21 & 0 & u \\
\hline \multicolumn{6}{|l|}{$\begin{array}{l}\text { Contact Addresses or } \\
\text { Feedback Mechanism: } \\
\text { E-mail }\end{array}$} \\
\hline Breul et al, ${ }^{20} 1999$ & No e-mail address on French hospital sites & 25 & 68 & 37 & $\mathrm{v}$ \\
\hline $\begin{array}{l}\text { Butzke and Kramer, }{ }^{21} \\
2000\end{array}$ & $\begin{array}{l}\text { No e-mail addresses present on orthopedic department } \\
\text { homepages }\end{array}$ & 11 & 136 & 8.1 & $\mathrm{v}$ \\
\hline $\begin{array}{l}\text { Doupi and van der Lei, }{ }^{29} \\
1999\end{array}$ & $\begin{array}{l}\text { No provision of contact address or e-mail on drug information } \\
\text { sites }\end{array}$ & 3 & 14 & 21.4 & v \\
\hline Gillois et al, ${ }^{39} 1999$ & Cardiovascular risk prediction sites with no e-mail provided & 6 & 8 & 75.0 & $\mathrm{v}$ \\
\hline $\begin{array}{l}\text { Hoffman-Goetz and } \\
\text { Clarke, }{ }^{49} 2000\end{array}$ & $\begin{array}{l}\text { Breast cancer sites that did not provide e-mail (but telephone } \\
\text { number) }\end{array}$ & 17 & 136 & 12.5 & $\mathrm{v}$ \\
\hline O’Mahony, ${ }^{67} 1999$ & Webmaster e-mail not clearly displayed throughout the site & 31 & 60 & 51.7 & $\mathrm{v}$ \\
\hline $\begin{array}{l}\text { Ogushi and Tatsumi, }{ }^{68} \\
2000\end{array}$ & $\begin{array}{l}\text { E-mail address of the information provider not stated clearly } \\
\text { on Japanese sites of medical institutions (hospitals, clinics) }\end{array}$ & 276 & 1147 & 24.1 & $v$ \\
\hline Sing et al, ${ }^{77} 2001$ & No feedback e-mail address on airlines sites & 18 & 73 & 24.7 & v \\
\hline \multicolumn{6}{|l|}{$\begin{array}{l}\text { Contact Addresses or } \\
\text { Feedback Mechanism: } \\
\text { Feedback Tested }\end{array}$} \\
\hline Sing et al, ${ }^{77} 2001$ & $\begin{array}{l}\text { No response to unsolicited e-mails asking airlines for malaria } \\
\text { prophylaxis recommendations }\end{array}$ & 30 & 55 & 54.5 & \\
\hline \multicolumn{6}{|l|}{$\begin{array}{l}\text { Miscellaneous: Disclaimers } \\
\text { (General) }\end{array}$} \\
\hline $\begin{array}{l}\text { Doupi and van der Lei, }{ }^{29} \\
1999\end{array}$ & No disclaimers on drug information sites & 0 & 14 & 0 & w \\
\hline Groot et al, ${ }^{43} 2001$ & No disclaimer & 14 & 36 & 38.8 & w \\
\hline Pandolfini et $\mathrm{al}^{70} 2000$ & No disclaimer ("not a substitute for professional care") & 15 & 19 & 78.9 & w \\
\hline $\begin{array}{l}\text { Tu and Zimmerman, }{ }^{86} \\
2001\end{array}$ & No caveats on eating disorder sites & 84 & 97 & 86.6 & w \\
\hline $\begin{array}{l}\text { Veronin and Ramirez, } \\
2000\end{array}$ & $\begin{array}{l}\text { No disclaimer (eg, for "educational purposes only" or "not a } \\
\text { substitute for medical advice") on sites about Opuntia }\end{array}$ & 146 & 184 & 79.3 & w \\
\hline $\begin{array}{l}\text { Miscellaneous: Disclaimers } \\
\text { (Specific) } \\
\text { Kihlstrom, }{ }^{53} 2001\end{array}$ & $\begin{array}{l}\text { No disclaimer on pharmacy benefit management sites that } \\
\text { offer medical advice saying that "medical advice provided } \\
\text { is not designed or intended to replace the relationship } \\
\text { between the visitor and the health care provider" }\end{array}$ & 4 & 17 & 23.5 & \\
\hline \multirow{4}{*}{$\begin{array}{l}\text { Tu and Zimmerman, } \\
2001\end{array}$} & No disclaimer of limitations on eating disorder sites & 90 & 97 & 92.8 & \\
\hline & No disclaimer of scope on eating disorder sites & 90 & 97 & 92.8 & \\
\hline & No disclaimer of authority on eating disorder sites & 84 & 97 & 86.6 & \\
\hline & No disclaimer of currency on eating disorder sites & 97 & 97 & 100 & \\
\hline $\begin{array}{l}\text { Veronin and Ramirez, }{ }^{89} \\
2000\end{array}$ & $\begin{array}{l}\text { No FDA-disclaimer ("this product has not been evaluated by } \\
\text { the FDA“) on sites about Opuntia }\end{array}$ & 172 & 184 & 93.5 & \\
\hline
\end{tabular}


Online Table B. Overview of Quality Criteria Used by Studies and Their Evaluation Results* (cont)

\begin{tabular}{|c|c|c|c|c|c|}
\hline Study, Year & Description & $\begin{array}{c}\text { Not } \\
\text { complying }\end{array}$ & Total & $\begin{array}{c}\text { Not } \\
\text { Complying, \% } \\
\end{array}$ & MA† \\
\hline Miscellaneous: Copyright Notes & No copyright notes on drug information sites & 0 & 14 & 0 & $\mathrm{x}$ \\
\hline $\begin{array}{l}\text { Hoffman-Goetz and Clarke, }{ }^{49} \\
2000\end{array}$ & Breast cancer sites that did not provide copyright note & 55 & 136 & 40.4 & $x$ \\
\hline Kihlstrom, ${ }^{53} 2001$ & $\begin{array}{l}\text { Pharmacy benefit management sites not including a copyright } \\
\text { notice }\end{array}$ & 24 & 71 & 33.8 & $\mathrm{x}$ \\
\hline Shon and Musen, ${ }^{76} 1999$ & No copyright notice & 51 & 97 & 53 & $\mathrm{x}$ \\
\hline \multicolumn{6}{|l|}{$\begin{array}{l}\text { Editorial Review Process/Editorial } \\
\text { Board }\end{array}$} \\
\hline Breul et al, ${ }^{20} 1999$ & No editorial committee on French hospital sites & 61 & 68 & 90 & $\mathrm{y}$ \\
\hline $\begin{array}{l}\text { Griffiths and } \\
\quad \text { Christensen, }{ }^{42} 2000 \\
\end{array}$ & No editorial board on depression sites & 16 & 21 & 76 & $\mathrm{y}$ \\
\hline Groot et al, ${ }^{43} 2001$ & No editorial review process & 27 & 36 & 75 & $\mathrm{y}$ \\
\hline Latthe et $a l,{ }^{54} 2000$ & Did not provide editorial review process & 9 & 9 & 100 & $\mathrm{y}$ \\
\hline Latthe et al, ${ }^{55} 2000$ & Did not provide editorial review process & 32 & 32 & 100 & $\mathrm{y}$ \\
\hline \multicolumn{6}{|l|}{$\begin{array}{l}\text { Miscellaneous: External Review } \\
\text { Process }\end{array}$} \\
\hline Latthe et al, ${ }^{56} 2000$ & $\begin{array}{l}\text { No 'seal of approval' from a credible individual or group as } \\
\text { evidence of the review process }\end{array}$ & 12 & 12 & 100 & \\
\hline $\begin{array}{l}\text { Ogushi and Tatsumi, } 68 \\
2000\end{array}$ & $\begin{array}{l}\text { No seal showing the trustworthiness of the site on Japanese } \\
\text { sites of medical institutions (hospitals, clinics) }\end{array}$ & 1142 & 1147 & 99.6 & \\
\hline $\begin{array}{l}\text { Miscellaneous: Evidence Hierachy } \\
\text { Groot et } a l,{ }^{3} 32001\end{array}$ & Did not show hierarchy of evidence & 30 & 36 & 83.3 & z \\
\hline Latthe et $\mathrm{al}^{54} 2000$ & Did not show hierarchy of evidence & 5 & 9 & 55.6 & z \\
\hline Latthe et al, ${ }^{55} 2000$ & Did not show hierarchy of evidence & 26 & 32 & 81.3 & z \\
\hline Latthe et $a l,{ }^{56} 2000$ & Did not show hierarchy of evidence & 7 & 12 & 58 & z \\
\hline $\begin{array}{l}\text { Miscellaneous: Level of Evidence } \\
\text { Martinez-Lopez and } \\
\text { Ruiz-Crespo, } 611998 \\
\end{array}$ & $\begin{array}{l}\text { "Simply expresses personal opinion" (as opposed to "relevant } \\
\text { information") on pages about rotator cuff rupture }\end{array}$ & 10 & 57 & 17.5 & \\
\hline $\begin{array}{l}\text { Miscellaneous: Imprint } \\
\text { Shon and Musen, }{ }^{76} 1999\end{array}$ & No editorial statement on site & 66 & 97 & 68 & \\
\hline von Danwitz et al, ${ }^{91} 1999$ & No imprint (editorial statement) & 8 & 39 & 21 & \\
\hline $\begin{array}{l}\text { Miscellaneous: Site Statistics } \\
\text { Breul et al, }{ }^{20} 1999\end{array}$ & French hospital sites not providing user statistics & 58 & 68 & 85 & \\
\hline $\begin{array}{l}\text { Hernández-Borges et al, }{ }^{47} \\
1999 \\
\end{array}$ & Pediatric Web sites not providing a visit counter & 354 & 363 & 90 & \\
\hline \multicolumn{6}{|l|}{$\begin{array}{l}\text { Miscellaneous: Disclosure of } \\
\text { Charges }\end{array}$} \\
\hline $\begin{array}{l}\text { Hoffman-Goetz and } \\
\text { Clarke, }{ }^{49} 2000\end{array}$ & $\begin{array}{l}\text { Breast cancer sites that did not provide information on } \\
\text { financial charges associated with products or services } \\
\text { associated with the site }\end{array}$ & 122 & 136 & 89.7 & \\
\hline $\begin{array}{l}\text { Thompson and Howard, }{ }^{85} \\
2000\end{array}$ & $\begin{array}{l}\text { HMO sites not providing information on monthly cost to } \\
\text { consumers on their Web site }\end{array}$ & 17 & 21 & 81.0 & \\
\hline \multicolumn{6}{|l|}{$\begin{array}{l}\text { Miscellaneous: } \\
\text { Confidentiality/Privacy }\end{array}$} \\
\hline $\begin{array}{l}\text { Galimberti and Jain, } \\
2000\end{array}$ & $\begin{array}{l}\text { Sites about hysterectomy where "confidentiality of data } \\
\text { relating to individual patients was not respected" (eg, } \\
\text { showing patients' photographs and full names) }\end{array}$ & 7 & 26 & 26.9 & \\
\hline Kihlstrom, ${ }^{53} 2001$ & $\begin{array}{l}\text { Pharmacy benefit management sites not providing a "clear } \\
\text { confidentiality statement" }\end{array}$ & 53 & 71 & 74.6 & \\
\hline $\begin{array}{l}\text { Ogushi and Tatsumi, }{ }^{68} \\
2000\end{array}$ & $\begin{array}{l}\text { Japanese sites of medical institutions (hospitals, clinics) not } \\
\text { having a privacy policy }\end{array}$ & 1145 & 1147 & 99.8 & \\
\hline \multicolumn{6}{|l|}{$\begin{array}{l}\text { Miscellaneous: } \\
\text { Encryption/Security }\end{array}$} \\
\hline $\begin{array}{l}\text { Hoffman-Goetz and } \\
\text { Clarke, }{ }^{49} 2000\end{array}$ & $\begin{array}{l}\text { Breast cancer sites that did not "indicate that information sent } \\
\text { by the user would be a secure transmission or had a } \\
\text { disclaimer indicating that messages would not be secured" }\end{array}$ & 129 & 136 & 94.9 & \\
\hline $\begin{array}{l}\text { Ogushi and Tatsumi, } 68 \\
2000\end{array}$ & $\begin{array}{l}\text { Japanese sites of medical institutions (hospitals, clinics) not } \\
\text { using encryption for transmitting personal information }\end{array}$ & 1147 & 1147 & 100 & \\
\hline $\begin{array}{l}\text { Miscellaneous: Cookies } \\
\text { Kihlstrom, }{ }^{53} 2001\end{array}$ & Pharmacy benefit management sites sending a "cookie" & 23 & 71 & 32 & \\
\hline $\begin{array}{l}\text { Miscellaneous: Metadata } \\
\text { Shon and Musen, }{ }^{76} 1999\end{array}$ & No metadata in source code & 45 & 97 & 46 & \\
\hline
\end{tabular}


Online Table B. Overview of Quality Criteria Used by Studies and Their Evaluation Results* (cont)

\begin{tabular}{|c|c|c|c|c|c|}
\hline Study, Year & Description & $\begin{array}{c}\text { Not } \\
\text { complying }\end{array}$ & Total & $\begin{array}{c}\text { Not } \\
\text { Complying, \% }\end{array}$ & MAt \\
\hline \multirow[t]{2}{*}{$\begin{array}{l}\text { Miscellaneous: Other } \\
\quad \text { Berland et al, }{ }^{15} 2001\end{array}$} & $\begin{array}{l}\text { Percentage of Spanish-language Web pages with neither } \\
\text { author nor date }\end{array}$ & ? & $?$ & 44 & \\
\hline & $\begin{array}{l}\text { Percentage of English-language Web pages with neither } \\
\text { author nor date }\end{array}$ & $?$ & $?$ & 9 & \\
\hline Groot et $\mathrm{al}{ }^{43} 2001$ & "No context provided" & 1 & 36 & 2.8 & \\
\hline \multirow[t]{2}{*}{ Kihlstrom,,$^{53} 2001$} & Pharmacy benefit management sites not carrying a HON logo & 69 & 71 & 97.2 & \\
\hline & $\begin{array}{l}\text { Pharmacy benefit management sites requiring additional } \\
\text { plug-ins }\end{array}$ & 9 & 71 & 13 & \\
\hline \multirow[t]{5}{*}{$\begin{array}{l}\text { Global Ratings } \\
\text { Ellamushi et al, }{ }^{32} 2001\end{array}$} & $\begin{array}{l}\text { Sites about pallidotomy rated "not useful" (from first } 30 \text { hits } \\
\text { found by a search engine) }\end{array}$ & 7 & $30 \|$ & 23 & \\
\hline & Sites about lumbar discectomy rated "not useful" & 10 & 30 & 33.5 & \\
\hline & Sites about hydrocephalus rated "not useful" & 3 & 30 & 10.5 & \\
\hline & Sites about glioma rated "not useful" & 11 & 30 & 36.5 & \\
\hline & Sites about carotid artery aneurysm rated "not useful" & 7 & 30 & 23.5 & \\
\hline Groot et $\mathrm{al}^{43} 2001$ & "Utility" criterion not fulfilled [unclear how this was evaluated] & 10 & 36 & 3.6 & \\
\hline Mallory, ${ }^{60} 1997$ & $\begin{array}{l}\text { HIV/AIDS sites rated "poor" (on a 4-point Likert scale: } \\
\text { poor/fair/good/excellent) }\end{array}$ & 2 & 69 & 3 & \\
\hline Peroutka, $^{72} 2001$ & $\begin{array}{l}\text { Headache page rated "less than optimal", ie, receiving }<51 \\
\text { points in the evaluation }\end{array}$ & 41 & 51 & 80 & \\
\hline $\begin{array}{l}\text { Suitability Assessment of } \\
\text { Materials (SAM) } \\
\text { Murphy et al, }{ }^{65} 2001\end{array}$ & $\begin{array}{l}\text { Based on the Suitability Assessment of Materials (SAM) score, } \\
7 / 8(87.5 \%) \text { of Web information materials, but only } \\
5 / 35(14.3 \%) \text { of printed patient information was deemed } \\
\text { unsuitable. The } 8 \text { patient education materials came from } \\
\text { only } 2 \text { different sites, so that it is questionable whether this } \\
\text { result is representative. }\end{array}$ & 7 & 8 & 87.5 & \\
\hline \multirow[t]{8}{*}{$\begin{array}{l}\text { DISCERNף } \\
\text { Türp et al, }{ }^{87} 2001\end{array}$} & $\begin{array}{l}\text { DISCERN item 2: Aims not reached (Web pages on } \\
\text { myoarthropathies of the mastication system) }\end{array}$ & 24 & 47 & 51.1 & \\
\hline & DISCERN item 3: Not relevant & 23 & 47 & 48.9 & \\
\hline & $\begin{array}{l}\text { DISCERN item 7: Does not provide details of additional } \\
\text { sources of support and information }\end{array}$ & 41 & 47 & 87.2 & \\
\hline & DISCERN item 8: Does not refer to areas of uncertainty & 38 & 47 & 80.9 & \\
\hline & $\begin{array}{l}\text { DISCERN item 9: Does not describe how each treatment } \\
\text { works }\end{array}$ & 40 & 47 & 85.1 & \\
\hline & $\begin{array}{l}\text { DISCERN item 10: Does not describe the benefits of each } \\
\text { treatment }\end{array}$ & 29 & 47 & 61.7 & \\
\hline & $\begin{array}{l}\text { DISCERN item 11: Does not describe the risks of each } \\
\text { treatment }\end{array}$ & 45 & 47 & 95.7 & \\
\hline & $\begin{array}{l}\text { DISCERN item 12: Does not describe what would happen if } \\
\text { no treatment is used }\end{array}$ & 31 & 47 & 66.0 & \\
\hline
\end{tabular}


Online Table B. Overview of Quality Criteria Used by Studies and Their Evaluation Results* (cont)

\begin{tabular}{|c|c|c|c|c|c|}
\hline Study, Year & Description & $\begin{array}{c}\text { Not } \\
\text { complying }\end{array}$ & Total & $\begin{array}{c}\text { Not } \\
\text { Complying, \% }\end{array}$ & MA† \\
\hline & $\begin{array}{l}\text { DISCERN item 13: Does not describe how the treatment } \\
\text { choices affect overall quality of life }\end{array}$ & 34 & 47 & 72.3 & \\
\hline & $\begin{array}{l}\text { DISCERN item 14: Is not clear that there may be more than } \\
\text { one possible treatment choice }\end{array}$ & 30 & 47 & 63.8 & \\
\hline & $\begin{array}{l}\text { DISCERN item 15: Does not provide support for shared } \\
\text { decision-making }\end{array}$ & 42 & 47 & 89.4 & \\
\hline & $\begin{array}{l}\text { DISCERN item 16: Overall DISCERN score } \leq 2 \text { (serious or } \\
\text { extensive shortcomings) }\end{array}$ & 27 & 47 & 57.4 & \\
\hline \multicolumn{6}{|c|}{ 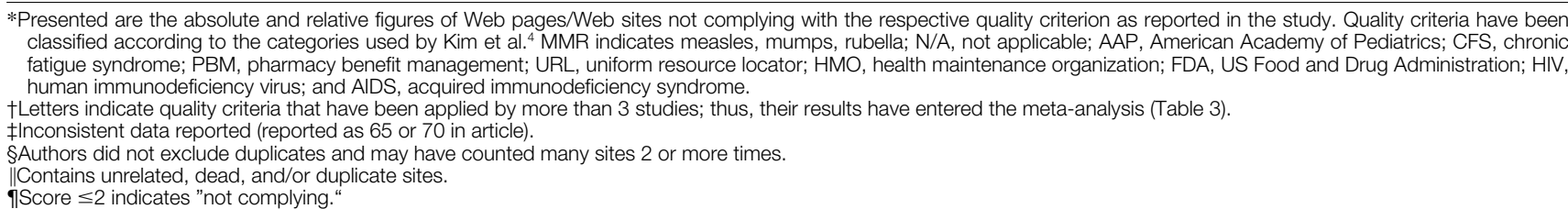 } \\
\hline
\end{tabular}

